CHALCERIAN PATHOS

Nina Helen Dorrance Appleton, Wisconsin

A.B., Dartmouth College, 1977

M.A., University of Virginia, 1981

A Dissertation Presented to the Graduate

Faculty of the University of Virginia

in Candidacy for the Degree of

Doctor of Philosophy

Department of English

University of Virginia

January, 1992

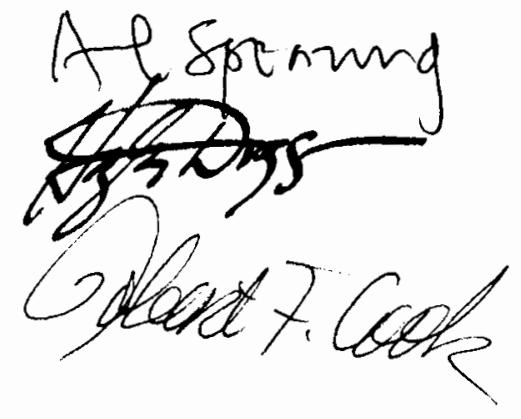


Copyright by

Nina Helen Dorrance

All rights reserved

January, 1992 


\section{CHAUCERIAN PATHOS}

Vina Helen Dorrance:

University of Virginia

Directors: A.C. Spearing and Hoyt N. Duggan

\section{ABSTRACT}

In this dissertation I consider pathos as a literary technique in the Second Nun's Tale, Man of Law's Tale, Prioress's Tale, Legend of Good Women, and Squire's Tale. The pathetic and sentimental strain in Chaucer's oeuvre may be defined as problematic not only because it occurs in just those works that have inspired the greatest modern interpretive disagreement among Chaucerians, but also because our current preference for restraint and irony has made sentimentality per se suspect. These tales have often been read as satiric, and my purpose in this study is to attempt a different estimate of their meaning and place in the Chaucer canon. I argue that they represent a stylistic experiment rather than an exercise in the construction of ironic personae. Chapter One undertakes a theoretical examination of the structure of narrative pathos itself, and a preliminary analysis of some medieval theories of decorum--that is to say, of how style intersects with subject-matter. In medieval terms the literary opposition between sacred and secular subject-matter reflects real metaphysical convictions: though both contain some 
form of truth, these truths are not of interchangeable value, and their literary representations must necessarily assume differing statuses. Much of the stylistic incongruity which modern readers have discerned in Chaucer's tales of pathos arises, I argue, from the poet's attempt to adapt the style traditionally associated with one kind of text onto another kind, or to extend tendencies already latent in its decorum. Because the very stock-in-trade of the saint's legend is the depiction of meaningful suffering, and because its intent and decorum are well-defined, the $\underline{\text { Second }}$ Nun's Tale can supply a standard against which the sufferers of the Prioress's and Man of Law's Tales may be evaluated. Chapters Two through Four establish such a decorum, and show that these latter tales adapt the style of sacred literature on to more secular subject-matter. Chapters Five and Six examine the decorum of Chaucerian pathos in two important forms of medieval secular narrative, the exemplum and the romance. 
CHAPTER ONE

CHAPTER TWO

CHAPTER FOUR

CHAPTER FIVF.

CHAPTER SIX

WORKS CITED
STABAT MATER. STABAT CANACEE: SOME MIDDLE ENGLISH SCENES OF PATHOS

page 12

"AFTER THE LEGEND IN TRANS --

LACIOUN": HAGIOGRAPHIC

DECORLM IN THE SECOND

NUN'S TALE

page 59

page 107 page 168

page 219 EXEMPI.ARY FORM IN THE

CHAUCERIAN PATHOS AND CHAL' CERIAN PARODY: CANACEE REVISITED AND TALE.

page 168

"THIS TALE IS SEYD FOR THIS CONCLUSIOUN-..": PATHOS AND LEGEND OF GOOD WOMEN

\author{
page 219
}

page 267 SENTIMENT AND FIGURAL STYLE IN THE PRIORESS'S PORTRAIT

page 299 


\section{PREFACE}

This study takes up an ethical theme in Chaucer, namely his interest in the pathetic. This interest, which manifests itself in a set of recurrent motifs and topoi--virtue in distress, wicked persecutors, the planctus--appears in such a variety of contexts that one might, on the face of it, conclude that Chaucer's experiments with literary pathos are primarily a matter of style rather than substance. My task here will be to argue the contrary position: that the formal features of Chaucerian pathos do indeed have an ethical slant--that they in fact constitute a key mode of Chaucer's poetics, and a rich opportunity for the literary historian to observe the very procedures whereby Chaucer constructs narrative meaning.

Some of my argument will rest on a theoretical discussion of literary pathos in general, but the bulk of this study will consider Chaucerian pathos in relation to its sources. Chaucer's most culturally immediate and familiar models of literary pathos were religious: the devotional lyric, the saint's legend, and the gospel meditation. In these genres the relation of pathos to ethos is clear. The private pleasure of the reader's "natural," grieving response to the sufferings of Christ, the Virgin, and the martyrs 
is not merely aesthetic. It is a form of devotion subservient to the cultural and moral norms of Christian doctrine. In other words, the pathos of late medieval religious literature evokes literary responses in the interests of supra-literary goals. My discussion of the Canterbury tales of pathos will show that in adapting these models Chaucer generally moves in the direction of secular narrative. That is to say, with the exception of the Second Nun's and Prioress's Tales, his pathetic victims are rarely sacred or miraculous figures, and the experience of reading these tales is (in contrast to the experience of authentic devotional literature) less clearly subordinate to the specific practices of corporate Christian worship. For all their secular orientation, however, Chaucerian sufferers characteristically raise urgent questions about the relation of human conduct to happiness, and the narrative situations in which they appear demand ethical interpretation. Chaucer's adaptations of Christian pathos tend, therefore, to present hermeneutic difficulties similar to those found in the Troilus, The Knight's Tale, and The Legend of Good Women. In these texts, whose immediate literary model is the classical or courtly love-complaint, Chaucer's employment of the topoi of suffering in a sympathetically-constructed pre-Christian world has caused notorious twentieth-century disputes about the ethical norms against which the characters' actions are to be 
understood. Chaucer's tales of pathos, in short, pose interpretive puzzles directly related to their adaptation of certain established models of language and narrative motif. My interest here will be in how these formal features of Chaucerian pathos intersect with larger problems of meaning. My analysis proposes particular elucidations of particular texts, but its larger goal is a more precise appreciation of Chaucer's overall technical achievement as a secular poet.

Pathos, like tragedy (its more prestigious sibling) casts an aesthetic eye upon troubling regions of human experience. Both pathos and tragedy invite us to gaze on misfortune, error, injustice; and both encourage us to witness and share the protagonist's distress. But tragedy--at least in the traditional Bradleyan sense--makes only incidental use of the moral response which the real-life spectacle of error and injustice might normally evoke. Our contemplation of the tragic hero's fall from greatness is rendered mysteriously satisfying by our sense that his catastrophe follows naturally upon his own character and choices. Our purely moral judgments upon his situation are secondary to the final effect. Whenever tragedy does seem to invoke clear moral categories of villainy and virtue, it tends to shade into melodrama--that is, into the realm of pathos.

Pathos eschews the tragic convergence of character and 
circumstance as an explanation for its painful outcome. Instead it forces the audience to consider, often with considerable indignation, how and why suffering is visited upon the harmless, the humble, the quietly virtuous, and the supremely well-intentioned. In short, it rejects the moral inevitability of catastrophe. In this sense pathos is directly concerned (as tragedy often is not) with the problem of unmerited evil. It is, despite its reputation for simple-mindedness and aesthetic naiveté, the more intellectually and morally anxious of the two modes.

That is not to say, however, that pathos is (to borrow a notion from Aristotle) "more philosophical" than tragedy. The characteristic philosophical response to the problem of evil is theodicy. In medieval culture this strategy is most fully represented by Boethius' Consolation of Philosophy, which explains evil by explaining it away. The Consolation begins with a vivid evocation of grief: the prisoner's only companions in exile are the Muses, and his only solace is the lyric outpouring of the first metrum. In its emphasis on the prisoner's isolation and unjust suffering, and in its expression of sorrow via formal complaint, metrum one of the Consolation is very much a scene of pathos. To this initial anatomy of despair, however, Lady Philosophy offers a counter-perspective. She unequivocally identifies the prisoner's state of mind as illness, a morbid dwelling upon the 
mere appearance of bondage and misfortune. She treats his experience of evil by denying its real existence: misery and injustice are, to the purified vision of philosophy, simply illusions and errors of perspective.

Chaucer certainly respected Boethian theodicy. He sometimes chose to borrow its arguments in his own poetry. But just as often he chose a different treatment of evil: one that does not dismiss the experience of suffering as illusory, but which rather gazes steadily upon the concrete experience of the suffering individual. This refusal--at least on the technical, mimetic level--to disregard the sensations of the moment and to rise above the burden of present circumstances is perhaps simply one measure of Chaucer's status as poet rather than philosopher. Boethius finds significance above the prisoner's present circumstances, in a providential pattern large enough to miniaturize (and thus to discount) the prisoner's daily insult of exile and incarceration. That pattern, significantly, has no place in it for the Muses. Chaucer's treatment of suffering, on the other hand, often lingers among the microcosmic symptoms of grief and loss--tears, distress, physical illness or injury, the torments of remembered happiness. He seems, through this focus, to grant the sufferer's private experience a metaphysical as well as poetic validity. 
Chaucer's is the poet's choice; but that choice is not in fact easier than the philosopher's, for the poet, no less than the philosopher, is obligated to make sense of the experience he presents. Chaucer's sufferers inhabit a general atmosphere of moral discomfort at the injustice of their situations, a discomfort which they may themselves express, or which they may elicit from the narrator or from other characters within the poem. Insofar as their suffering raises questions about the providential order itself, the experiential intersects with the philosophical. Such an atmosphere suffuses the tales of Constance, Griselda, and the good women of the Legend. Perhaps Chaucer's strongest general statement of moral indignation at unmerited suffering occurs in the "Complaint of Mars":

To what fyn made the God that sit so hye, Benethen him, love other companye, And streyneth folk to love, malgre her hed? And then her joy, for oght I can espye, Ne lasteth not the twynkelyng of an ye, And somme han never joy til they be ded. What meneth this? What is this mystihed? Wherto constreyneth he his folk so faste Thing to desyre, but hit shulde laste?

$(218-26)$

Here, of course, the speaker is not just a god but also a planet, and much of the poem's wit lies in our knowledge that his separation from the beloved depends on mechanical, cosmic forces. But while a similar dramatic irony often surrounds Chaucer's 
pathetic figures, especially his lovers, it does not altogether blunt the poignancy of their questions about providential justice. The poet's task, no less than the philosopher's, is to find an intelligible framework for unmerited suffering--if not to explain it away, then at least to discover its significance. Chaucer, unlike Boethius, often chooses to answer such questions about suffering within the limited, sublunary context of the individual's perceptions. This study examines that choice. It will analyze not just the workings of certain pathetic moments in Chaucer's poetry, but also how Chaucer's interest in pathos leads him to experiment with distinctive ways of investing represented experience with meaning .

Chaucer's tales of pathos constitute no small part of his canon, and they should interest us not least because they challenge the long-prevailing view of Chaucer as genial satirist. Often critics have sought to neutralize the puzzling effects of Chaucerian pathos through the application of ironic readings, and I will argue that this procedure more often obscures than illuminates. Indeed, my claim is that a relatively direct appreciation of Chaucerian pathos is relevant to our understanding of Chaucer's art as a whole. The tales of pathos pose, for instance, an interesting challenge to our habitual notions about Chaucerian style and rhetoric. All these texts have traditionally been regarded as 
employing a considerable degree of "stylization" in their treatment of suffering. That is, Chaucerian sufferers adopt a strongly conventionalized stance: they perform suitably emblematic gestures of despair and/or humility, and they utter a highly crafted, traditional language of complaint. In this regard, all Chaucer's pathetic figures suffer by the book and within the bounds of literary decorum. Their language often employs the "courtly" style which Charles Muscatine identifies as one major strain of Chaucer's poetic craft. To this he opposes a "naturalistic" style of "bourgeois realism," which takes scrupulous notice of the gritty, particularized world of things, and which is best exemplified by the fabliau. In theory Muscatine insists on the basic conventionality of both styles--both depend, he argues, on a received tradition of subject-matter and diction--but in practice his analysis tends to favor naturalism, which seems to him to grasp more fully the actual textures and practical exigencies of "real life":

Thus we can say that a style which we instinctively call "elevated" is better adapted than a naturalistic style to support an idealistic attitude towards experience. The non-representational traits of the former--often called the "conventional" traits--are among the best resources open to the poet who wishes to deal with that level of experience not immediately apprehensible to the senses. Conversely, the adoption in a naturalistic style of certain traits from the idiom of common life, representationalism generally, is a sign of the particular potency of this style in the expression of a phenomenalistic attitude 
towards experience. (Muscatine 3)

Muscatine's own preference for the concrete world of "common life"--a preference implied by the opposition of "conventional" to "naturalistic" in this passage--is certainly characteristic of modern readings of Chaucer. And in all fairness we should acknowledge that it's a preference Chaucer himself often seems to share. But behind it lies a stylistic distinction which Chaucer did not, I think, make so easily: "If Chaucer uses conventional style to navigate the insubstantial air of the spiritual world, naturalism serves his soundings of the world of matter" (Muscatine 198). We should certainly hesitate to accept this opposition between matter and spirit as authentically Chaucerian, especially when it comes to his representations of suffering. Muscatine's definition of the interplay between rhetoric and reportage in Chaucer's style is a powerful tool of analysis, but it is not particularly applicable to Chaucerian pathos.

The grand style often appears in Chaucer, it is true, as a satirical exposure of certain kinds of posturing or insincerity. But in the pathetic moment it just as often becomes the author's key technique for making the scene apprehensible, emotionally vivid, and fully "phenomenalistic" (Muscatine 3). Chaucerian pathos contrives to be both rhetorical and "true to life." It addresses a level of emotional experience which is at one and the 
same time phenomenalistic--rooted in individual sense perceptions and circumstances--and also available to the observer only through expressive, rhetorically constructed language--whether that language is the sufferer's (as in the planctus), or that of the interpreting narrator (as in the Man of Law's, Prioress's, or Clerk's Tales).

The representation of individual suffering leads Chaucer into a realm of experience that is private, potentially disturbing, sometimes idiosyncratic, and often difficult for literary critics to rationalize. His suffering protagonists and their narrators, preoccupied with the immediate phenomena of grief and injustice, struggle not just to articulate this experience, but also to make sense of it: to account for the evils that befall the virtuous and well-intentioned. Their struggle is also the poet's. Medieval culture offered various solutions to the problem of misery and evil; but as we have noted and as we shall see in more detail, such solutions tend to sacrifice the texture of individual experience in the interests of imposing a larger pattern. For whatever reason--technical or temperamental--Chaucer is often unwilling to make that sacrifice.

Hence Chaucerian pathos is an excellent vehicle for examining Chaucer's lifelong preoccupation with the way that narrative versions of experience--stories--can be invested with significance. 
Troilus and Criseyde, for instance, has always been recognized as a major achievement in the development of English narrative poetry. I would suggest that a large part of its innovation lies precisely in Chaucer's effort to communicate, with ever greater and greater particularity, the experiential textures of his hero's joy and grief. But even though the vast bulk of the poem is devoted to a minute representation of secular experience, and to the peculiarly literary pleasures to be derived from such mimesis, Chaucer also strives to maintain the larger philosophical vision expressed in the palinode. Thus the Troilus offers a dynamic (and perhaps not entirely successful) experiment in the construction of meaning. I will attempt to show that a similar interest in the relation of experiential detail to larger patterns of significance is strongly present in Chaucer's other tales of pathos, and that these tales thereby offer a kind of window into Chaucer's development as a serious secular poet. No doubt this claim is surprising in light of the generally "religious" orientation of the Canterbury tales of pathos. My examination of analogous religious texts, however, will show that Chaucer's tales depart significantly from their models in their treatment of suffering, and that this departure is regularly in the direction of what is appropriately called a secularization of literary response. Hence these tales, too, reveal Chaucer's experiments in signification. 


\section{CHAPTER ONE}

STABAT MATER, STABAT CANACEE:

SOME MIDDLE ENGLISH SCENES OF PATHOS

Subsequent chapters of this study will undertake readings of specific Chaucerian texts. These readings, however, depend on certain assumptions about pathos, and also about the status of secular literature in the Middle Ages. This introductory chapter will, therefore, attempt the necessary definitions. I begin with a discussion of pathos itself, both as a formal configuration of character and situation, and also as a category of literary re-sponse. I then examine the conditions under which pathos may pose difficulties for the interpreter. I will argue that the wellknown incorporation of pathos into the idiom of late medieval devotional literature is fundamentally unproblematic. Devotional pathos, by virtue of its subordination to the larger context of Christian doctrine and observance, avoids the ambiguity inherent in its meticulous depiction of suffering. Pathos in secular narrative, however, is a different matter: its details, insofar as they may lack clear affiliation to a larger pattern of significance, place a far greater interpretive burden upon both author and reader. 
The greatest obstacle to a modern understanding of Chaucerian pathos is a kind of reflex aversion to pathos itself. Chaucer's term "pitous" describes the entirely legitimate category of whatever evokes sympathy (see Gray, "C. and 'Pite," for a semantic survey); the modern application of terms like "pitiful" and "pathetic" is more restricted and dismissive. For us these words designate not so much the viewer's empathic response to suffering as his perception, often mingled with a certain condescension or even contempt, of the sufferer's weakness and helplessness. Northrop Frye's view of pathos in the Anatomy of Criticism is characteristically modern: it is, he says, "a queer ghoulish emotion" (Frye 39). He associates it with low mimetic tragedy, where "pity and fear are neither purged nor absorbed into pleasures, but are communicated externally, as sensations" (Frye 38). His remarks about its "ghoulish" quality reinforce his claim that pathos results from an insufficient transformation of raw emotion into true aesthetic experience. Pathos fails, in short, to achieve catharsis, and this failure explains its essentially inartistic and unliterary nature:

The death of an animal is usually pathetic, and so is the catastrophe of defective intelligence that is frequent in modern American literature. . . . Pathos is a queer ghoulish emotion, and some failure of expression, real or simulated, seems to be peculiar to it. It will always leave a fluently plangent funeral elegy to go and batten on something like Swift's memoir of Stella. Highly articulate pathos is apt to become a 
factitious appeal to self-pity, or tear-jerking. (Frye 39)

Frye's remarks here are in fact relatively charitable. The more usual judgment is that pathos belongs to the realm of "popular," commercial literature, and that its natural audience is both unsophisticated and intellectually immature. A literary historian's interest in the pathetic is thus respectable only insofar as it is antiquarian: major figures like Sterne and Richardson can earn full modern acceptance only as representatives of a sociologically reconstructed "cult of sensibility," while lesser works like Mackenzie's Man of Feeling remain, even after formidable apologetics, at best a kind of literary slumming and at worst a species of camp. Our sense of cultural superiority to such art is perhaps justifiable. My immediate task, therefore, is not so much to argue against our prejudices as to find clearer and more useful terms for analyzing the phenomenon itself.

Let me begin by proposing an immediate corrective. Pathos may well be queer and ghoulish, but it is not, properly speaking, an emotion. One might think of it once again in comparison with tragedy: pity and terror are tragedy's characteristic emotions, but tragedy itself is not an emotion. Rather it is a particular configuration of persons and events which give rise to a tone or atmosphere that we call "tragic." I suggest that a similar distinction ought to be applied to pathos. Sympathy and indignation 
are emotions, but pathos (at least as I mean to use the term here) is a situation.

Unlike tragedy, which may be embodied in a wide variety of configurations, pathos manifests itself in a remarkably uniform scenario. It requires first of all a sufferer or victim, who is generally helpless, innocent, and female. As everyone knows, pathetic figures in literature tend to be children, women, lunatics, simpletons, or the aged--those who are weak, disenfranchised, and who in any other context would never become the subject of panegyric. Obvious Chaucerian examples include Constance, Griselda, the Prioress's little clergeon, and Virginia. Chaucer's pathetic lovers are often noble and socially powerful, but their subjection to love renders them weak and incapable of direct action on their own behalf. The women of the Legend additionally face physical vulnerabilities such as isolation and abandonment. Troilus, the only adult male among Chaucer's major pathetic figures, is doubly weakened: he is psychologically debilitated by his own erotic misery, and he is also socially powerless, since his commitment to secret love forbids any attempt to forestall Criseyde's departure, a step which might otherwise be within his prerogative as a prince.

The sufferers in the scene of pathos are often not just weak but also unwitting. They are ignorant of the ways of the 
world and also unaware of the powerful effect they create in those who behold their suffering. In this regard pathetic heroes and heroines are very much akin to the naive, unself-conscious figures of pastoral. But as Schiller notes, naiveté acquires value and interest only for those who can no longer share it. Hence the scene of pathos demands not just a naive sufferer, but also a self-conscious witness to the suffering. Sometimes, as in the planctus, the reader is the sole audience; sometimes the configuration enlarges to form a triangle composed of sufferer-narratorreader. Sometimes (particularly in hagiography) other witnesses also participate. Interestingly, the pathetic sufferer may or may not be aware of the presence of these others; indeed, he or she need not even be sentient, as in the familiar case of the lamentation over Christ's body. That fact makes it clear that pathos has less to do with the victim's suffering than with the observer's response. The mainspring of pathos in literature is not the mere fact of the sufferer's pain, but rather the observer's imagined. participation in another's distress.

The basic configuration of sufferer and witness gives rise to a much greater variety of responses than words like "pity" or "sympathy" can encompass. The audience may feel grief, wonder, moral approbation, terror, and indignation. The narrative scenario may be physically quite static (one thinks, for example, of 
death-bed scenes as quintessentially pathetic). But in fact the scene of pathos always inaugurates its own psychological dynamic, a kind of "story" of the observer's response. The working-out of this story--rather than the actual suffering which triggers it--is often the author's real interest. At the same time, however, the reader's response to a scene of pathos can develop in various directions, and is not always within the author's control--hence the tendency of one era's pathos to become another era's parody or bathos. Sentimentality may indeed be part of the pathetic mood, but it is not a necessary component of pathos, and ought properly to be distinguished from it. As I mean to use the term, sentimentality denotes pity (or some other tender emotion) mingled with a certain complacent enjoyment, whether of one's own emotional state, or of the aesthetic qualities displayed by the object of that emotion.

Unlike tragedy, pathos rarely involves the fate of nations or the fall of kings; instead it is private, hidden, and without larger consequences. A curious feature of pathos is precisely its capacity to interest us in persons and situations which seem, on the face of it, too trivial for literary commemoration. (Indeed, when we don't particularly care about the character or situation offered for our emotive contemplation, we usually find the poet's treatment maudlin rather than touching.) The humble or humiliat- 
ed protagonist of the pathetic scenario rarely comes to occupy center stage because of his or her greatness. On the contrary, Frye rightly locates the appeal of pathos (and also its potential for triviality) in its reliance on the "natural," visceral facts of the human condition: "pathos presents its hero as isolated by a weakness which appeals to our sympathy because it is on our own level of experience" (Frye 38).

But the fully achieved scene of pathos must do more than just remind us of our shared human vulnerability. In order to justify our attention, the pathetic hero or heroine must somehow transcend the limits we would find in ourselves were we in the same situation. In other words, the sufferer must be presented as eminently worthy not just of sympathy, but also of moral approbation. Sometimes the sufferer is admirable because he or she endures the pain so well: we respect Cecilia's triumph of spirit over the frailty of the physical body, and wonder at Griselda's or the little clergeon's display of moral power where we had previously seen only weakness. This part of the response may also involve pleasure in seeing a disruption of the worldly hierarchy--wisdom coming out of the mouths of babes.

But regard for stoicism is still only one component of our total response. Just as important is our sense of being wrenched into a newer, fuller awareness of someone or something we 
wouldn't otherwise have noticed. Pathos illuminates events and feelings that might otherwise be overlooked or hidden by the traffic of the greater world: the murder of a child in a busy city, the abandonment of a girl on a faraway shore, the heroic patience of a wife consigned to domestic purgatory, the pangs of a private love-loss in the midst of war. The key thing is that we achieve an awareness of these things in and of themselves. In the isolation of a splendid, tableau-like close-up, the pathetic figure seems, for all his or her vulnerability, curiously absolute and self-contained.

As Frye rightly notes, pathos appeals to our common bodily experience. It arises from the observer's intimation of another's pain, and above all it arises when our apprehension of the sufferer's distress intersects with our awareness of his or her virtue. This response to another's pain is a distinctive feature of pathos, and by far the most difficult to analyze. Bodily sensation is by its very nature only partially communicable. The pleasures and pains of others are known to us chiefly by inference: from the observation of involuntary physical signs, and from words, which can convey physical experience only approximately. When we are in the presence of another's body in extremis, we are forced to interpret what we see in light of our own responses. We may find ourselves united with the other by a 
similarly produced sensation in ourselves, as is certainly the case with sexual response. Or we may, in the case of another's suffering, find ourselves unwillingly invaded by a kind of resonant apprehension of someone else's experience, an echo which feels both personal and alien. It "makes our flesh creep," disturbing our previous sense of integrity and well-being. Thus in witnessing another's suffering we receive intimations of what is usually ineffable: the previously disregarded (the sensations of others) becomes the insistent, and the familiar (our own unregarded wellbeing) becomes the uncanny. That fact is important to note, since conventionally we regard pathos and sympathy as a celebration of spiritual unity and fellow-feeling. In fact, however, the heart of the pathetic scenario is the perception of the suffering figure as an impinging Other.

One extreme case of this phenomenon is our response to the sufferings of animals, whose inability to use language makes their consciousness available to us mainly by inference, but it also operates in our responses to children. When we see them suffer, we experience a certain dilation of the spirit as we imaginatively as well as literally reach out to them. But we are also reminded, by our physical inability to co-experience their inarticulate pain, of the gulf dividing one consciousness from another. Hence pathos is both an exercise in empathy and also an experience of 
gaps and paradoxes: the gap between the sufferer's low social status and his or her high standing in the moral economy of the poem, the gap between the self and the other, the gap between our bodies--which are frail and vulnerable--and our spirits, which feel themselves able to do (or imagine doing) anything. The observer in the scene of pathos must struggle not just to make sense of the spectacle before him, but also of his own reactions. He is thus always both a witness and an interpreter. In modern culture the complexity and interest of pathos has been obscured by its manifestation in sentimental and trivial forms. Unfortunately, for us the archetypal scene of pathos is the death of Dickens' little Nell (or, perhaps even more unfortunately, the supposed death of little E.T.). In medieval culture pathos was not marginalized in this way. Indeed, the Middle Ages could hardly avoid taking the pathetic seriously, since its archetypal scene of pathos was undeniably non-trivial: it was, of course, the passion of Christ.

Gothic depictions of the crucifixion include all the essential elements of the pathetic scenario. At the center of a static tableau we find an innocent sufferer, humiliated, mutilated, and helpless. This figure is flanked by sorrowing witnesses who communicate their grief in extravagant gestures intended to inspire similar responses in the viewer. Outwardly the suffering 
Christ appears to be the lowest specimen of humanity; hence the scene directs our attention to something apparently minor and humble. In fact, however, the central position of the crucified Christ, together with the graphic rendering of his wounds, leads us to consider the unjust discrepancy between his physical humiliation and his moral authority. And indeed, his moral authority is supreme, for he is really the incarnate god, and his death will be the turning point in Christian history.

For the medieval devoté the clearest impression of this scene is probably not a simple empathic awareness of Christ's physical and psychological torments. These are as ineffable as the mystery of atonement itself. Instead the observer is chiefly conscious of his or her own reflections on Christ's implied suffering. The scene inspires the viewer to examine a whole series of discrepancies between himself and the dying god: at the most basic and visceral level the devoté becomes aware of the uncomfortable contrast between his own physical wholeness and the mutilated condition of Christ's body. At a deeper level of contemplation he perceives the irony of how his own bodily wellbeing hides the inward mutilation of his sins, whereas Christ's wounds proclaim his spiritual wholeness. He also becomes aware of the gap between Christ's perfect sinlessness and the moral flaws of humanity, of the gap between the freedom of his sacri- 
fice and the eternal bond of obligation it imposes on humankind. The meaning of the scene thus resides less in its painful details than in the viewer's efforts to accommodate those details to some interpretive context. That effort, however, is set in motion by the very elements which make the Gothic crucifixion a classic scene of pathos.

One might well object that the pain and sadness in this scene are both temporary and illusory--that the crucifixion is not, in its essential theological meaning, pathetic at all. Christ's physical defeat is really a spiritual triumph, and so the passion (like all of Christian history) cannot properly be described as either tragic or pathetic. And indeed, if we look at early medieval pictorial representations of the passion, we find just such a triumphal emphasis: the serene, rectilinear Christ as pantocrator, in majesty even while on the cross. What such a representation entails, however, is a substantial transmogrification of the bloody and humiliating events of the Gospels. The Romanesque crucifixion is not so much a narrative image as an emblem: its symbolic form conveys doctrine rather than history. An observer ignorant of Christian myth could not learn from it any but the most minimal narrative facts of the passion. He would instead see the harmonious, ordered lineaments of a divine ruler, powerfully if mysteriously superimposed upon the stark pattern of the cross. 
Late medieval representations of the passion, by contrast, emphasize the physical signs of Christ's creatural suffering, and also the grief of his companions. Here the observer ignorant of Christian myth and doctrine would find the image more narratively intelligible. Insofar as the Gothic crucifixion is a spectacle of human suffering, it evokes a more "natural" level of response. If the observer were also told that the suffering protagonist was the victim of betrayal and judicial miscarriage, and further that the most extravagantly grieving witness was the victim's own mother, he would no doubt feel a moral as well as physical discomfort. He would, in short, respond to the crucifixion as a scene of pathos. But he would not, on the basis of the painting's rendering of experiential detail, know that it represents the moment of atonement and the turning point of Christian history. To interpret the scene fully, he must also know its doctrinal context, which transcends and even runs counter to its accumulation of naturalistic detail.

Hence neither the Romanesque nor the Gothic crucifixion is intelligible apart from the Christian cult it serves. Both images depend on certain cultural contexts, and require an act of interpretation on the part of the viewer. The Romanesque crucifixion chooses to suppress the painful facts of the gospel narrative in favor of emphasizing its theological significance. The viewer must 
remind himself of the history on which the image depends. The Gothic crucifixion, like all scenes of pathos, elaborates the experience at the expense of the meaning. Its doctrinal implications must be supplied by the viewer.

In literary representations of the passion, however, we are often less conscious than in painting of how the reader contributes the crucial context for meaning. In part this has to do with the very nature of verbal designation: instead of a certain set of shapes, gestures, and decorative details that demand our inference that the persons presented to us are Christ, Mary, the Magdalen, St. John, and so on, literary characters generally first appear to us as with unambiguous labels, whether these are names or such relational terms as "son" and "mother." And because the poet can reproduce the words and thoughts of the protagonists, as well as his own commentary on the scene, he can both narrate events and explicate their meaning. Literature should, in other words, contain within itself its own keys to interpretation. Hence we are strongly inclined to regard narrative versions of the passion as self-sufficient in a way that painted images are not.

As many scholars have noted (in particular Rosemary Woolf and Douglas Gray, Themes and Images) late medieval lyrics on the passion place a typically Gothic emphasis on a wealth of painful 
naturalistic detail. The slightly lurid character of the late medieval passion lyric has occasioned a certain dismay among its modern students, and I would argue that their distaste arises from more than just modern decorum. It is, in fact, connected to the formalist expectation that a literary work present a selfcontained narrative and/or philosophical statement. My example for discussion will be the passion lyric "Stond wel, moder, vnder rode" (reproduced as Appendix A to this chapter), and I will argue that it offers a key example of the contingent nature of literary expression. Insofar as it is lyric, it presents the selfcontained emotions of a moment. But insofar as it is a scene of pathos, it demands the reader's interpretive involvement, and insofar as it draws on the complex mythos of Christianity, it relies on the audience's extra-textual knowledge of certain cultural norms.

The peculiarly literary quality of these relationships is worth emphasizing, since they imply a bit more than just the "work-and-its-background" model of the history of ideas. Siegfried Wenzel has devoted considerable effort to showing that the milieu for many Middle English Lyrics is fundamentally homiletic: however much these poems may have been independently appreciated for their aesthetic qualities, they were also often employed as exempla and even as division-schemes by preachers. Wenzel's 
work is important for its demonstration of the relation of the lyric to the larger professional concerns of those who wrote and collected them; he offers an important corrective to our own sense that poetry exists independent of a context of patronage and function. But his method fails, I think, to grasp the peculiar textual status of these literary appendices to public worship.

As Wenzel has shown (Preachers 21-48), the earliest English religious lyrics are translations and adaptations of Latin hymns. The form and language of these Latin originals are inspired by the model of the liturgy, and Wenzel argues that their artistry and effectiveness depend on "the meanings which these particular biblical images or events had acquired through centuries of an exegetical tradition reflected in both theology and the liturgy" (Wenzel, Preachers, 32). The very firmness of exegetical tradition offers the poet a certain linguistic license to experiment with startling syntax and imagery, and a considerable opportunity for devotional expansiveness. English lyricists, in their struggles to achieve vernacular imitations of these hymns, often preserved the emotional freedom, but lost the linguistic associations which connected the Latin originals to their roots in the language of the liturgy. English lyrics, Wenzel argues, lose something in translation.

And what they lose is intellectual as well as linguistic. The 
complex exegetical resonance of Latin devotion is reduced to simple vernacular piety. Among Wenzel's examples of this sort of vulgarization is the passion lyric "Stond wel, moder, vnder rode," composed in the second half of the thirteenth century and surviving in six versions. It consists chiefly of six-line stanzas of dialogue between the dying Christ and his grieving mother, and its origins, so far as we can tell, are monastic. It is apparently one of a group of poetic adaptations of such Latin prose passion narratives as the pseudo-Anselmian Dialogus Beatae Mariae et Anselmi de passione Domini (PL 159:271-90) and the pseudo-Bernardine Liber de passione Christi (PL 182:1133-42). Its relation to the Latin hymn tradition is suggested by the fact that two surviving versions (Royal MS. 12, E.i and St. John's College, Camb. MS. 111) include musical notation closely adapted from the Latin sequence Stabat iuxta Christi crucem.

Wenzel regards "Stond wel, moder" as a typical instance of the early English lyricists' tendency to neglect doctrinal complexity in favor of "an aura of intimacy, sympathy, and compassion" (Wenzel, Preachers 48). Wenzel notes that dialogue-form is here used more exclusively and systematically than in either of the putative sources, and argues that it creates a certain tension and opposition between the speakers: "While Christ tries to console his mother, the latter seemingly fails to understand the necessity 
for his suffering" (Preachers 49). This opposition, he argues, is never satisfactorily resolved:

One may well ask whether there is a resolution to this tension or antithesis between the two speakers, a note of understanding resignation on Mary's part, as Christian theology and meditation would require. One may find such a note in line 52: "Sune, y wyle wi'the funden" ("Son, I will go with thee"); but if this line is intended to express acceptance and resignation, the effect is immediately cancelled by the next two lines, in which Mary reverts to her earlier complaint at the greatness of her suffering. . . . It is true that in the full versions of the poem the dialogue is followed by a narrative stanza speaking of Mary's Easter joy. But within the dialogue proper it is not at all clear whether or not Mary comes to understand and accept the need for her son's death. (Wenzel, Preachers, 50)

According to this account the speakers simply repeat, with variations, their respective points of view, and Wenzel's remarks betray a certain impatience with this emotionalism and lack of closure. In noting that Mary never seems to achieve the level of understanding that "Christian theology and meditation would require," Wenzel implies that the lyric encourages a kind of spiritual laziness, a refusal to move beyond the immediate phenomena of complaint towards the more difficult theology of triumph.

What Wenzel fails to observe, however, or at least to take seriously, is the degree to which the tension in the dialogue arises from its presentation as a scene of pathos. The central sufferer is clearly Christ, but it would be incorrect to say that 
the poem explores his experience of the passion. Instead it is about Mary's response to that painful spectacle, and about her inability to transcend the limits of her natural, motherly reflexes. The dialogue-form emphasizes the poem's focus on the interaction of sufferer and witness, while an evident dichotomy between the physical and spiritual informs the repeated structure of juxtaposed statements. The fourth stanza is typical:

'Moder, nu y may pe seyn, bettere is pat ic one deye, pan al man-kyn to helle go.' 'Sune, y se bi bodi swngen, pi brest, pin hond, pi fot pur-stungen-no selli bou me be wo.'

To Christ's calm statement of theological necessity, Mary replies with the straightforward and unbearable facts of what she perceives.

In some manuscripts the text concludes with two stanzas of authorial commentary which reveal that the conflict between mother and son is temporary: "When he ros pan fel pi sorwe, / pe blisse spronge pe pridde morewe, / wen blipe moder wer pu po." These lines are, however, addressed directly to Mary by the poet; they occur, in other words, outside the dramatic structure of the lyric's scene of pathos. They add what Wenzel seems to find lacking--the reassurance that Mary's unseemly despair is the product of her limited viewpoint--but they do it in a way that emphasizes the emotional stalemate within the lyric proper. 
"Stond wel, moder" thus insists on the discrepancy between the experience of Christ's passion and its meaning.

Mary's persistently ground-level view of the event is consistent with the scene of pathos as we have defined it, as is her refusal to be comforted by Christ's loftier soteriological vision. Yet the unresolved juxtaposition of their voices is, as Wenzel notes, the poem's most distinctive feature. It seems both deliberate and strategic. But what end does it serve? The poem invites us to meditate on the grisly details of the passion, to let our minds play over the characters' discrepant voices, and apparently permits us to draw our own conclusions. In other words, it demands our interpretation. The situation is, of course, quite familiar to modern readers, and one can easily imagine a Browningesque dramatic reading that makes Mary the butt of the poem's ironies: her fixation on Christ's physical suffering prevents her from heeding the good news of the coming resurrection. The poet may thus intend to expose or even satirize the limits of an all-too-human, motherly, or even feminine disposition which is insensitive to any but the literal meaning of what it sees. One can also imagine (just barely) an interpretation that magnifies Mary's response and elaborates an irony at Christ's expense: in a bold affirmation of human emotion over reason and of experience over authority, the poet invites us to question the 
chilly, severe lessons of theology. The final stanzas which appear in some manuscripts are thus a kind of palinode, a reassertion of official doctrine that lends the poem closure, but that does not resolve its earlier subversive tendencies. The two readings lie side by side, offering the reader an attractively ambiguous and multivalent array of meanings. They invite us to reflect on the fundamental instability of literary meanings, and on the way that poetry preserves the complexity of "real life."

Interpretive possibilities such as these, insofar as they are inconsistent with Christian orthodoxy, seem to underlie Wenzel's uneasiness about "Stond wel, moder." One wonders, however, whether any medieval Christian would fully embrace either of these ironized explications. All attentive readers must correctly observe that the poem dramatizes the discrepancy between divine and human nature. But modern readers seem unduly troubled by the doubtful possibility that the poet's "slice of life" is intended to stand alone as a self-contained vision of what Christ's passion means. Wenzel himself notes that the first stanza of "Stond wel, moder" appears in a late thirteenth-century Latin sermon on the joys and sorrows of the Virgin (Wenzel, Preachers, 51), a fact which helpfully reminds us of the actual use to which the early English lyric could be put, and also of its connections to specific religious practices. But to say that the lyric has affiliations with 
orthodox public worship is not to say that it must simply reduplicate the religious practices it could be made to serve.

I will develop this topic at greater length in Chapter Two; for the moment it will suffice to note that "Stond wel, moder," like the gospel meditations from which it derives, and like the painted Gothic crucifixion, does indeed permit significant deviations from the decorum of public, collective worship and doctrine. These deviations, however, are not fundamentally subversive. Insofar as Christianity is a cult centered upon the deeds of Christ and his charismatic imitators, the heart of its doctrine is sacred narrative and its interpretation. Liturgy, the public and collective worship of the corporate church, is both a commentary on salvation history, and also a sacramental reenactment of its key moments. Its function is both praise and interpretation. But like the Romanesque crucifixion, liturgy transforms sacred history into a collation of emblems. The eucharistic sacrifice of the mass was, of course, the preeminent liturgical and theological evidence of God's continued presence among humanity, but its veiled, figural quality would have made it spiritually inaccessible without the aid of stories which themselves become a commentary on the ritual. The literature and art of late medieval "affective piety" insistently return the devoté to the stories from which these emblems are derived. Their literalism, their attention to natural- 
istic and homely detail, their attempt to evoke emotion--all these offered devotés a spiritual approach to the central events of Christian history; it is worth noting, furthermore, how many of the episodes chosen--the nativity, the agony in the garden, the stations of the cross, the moment before the resurrection, the death of the Virgin--are scenes of pathos. The late medieval interest in detailed narratives of the sacred, whether gospel harmonies, meditative lyrics, saint's legends, or genre paintings, testifies to a popular need to move closer to the central events from which doctrine was derived.

In fact, one might well say that a poem like "Stond wel, moder" serves essentially the same function as visual representations of the passion: it both illustrates and recalls. Its educative function is certainly there, but above all it makes vivid and concrete the central Christian doctrine of incarnate divinity. In its power to make the divine present to the reader it approaches the function of relics and icons. Icons have, of course, no formal liturgical function in the West as they have in the Eastern Church. Yet, as the scholarship on the "popular" religion of the European Middle Ages shows, the wonder-working image takes its place beside the relic as the focus of veneration, supplication, and community pride. In his recent book on hagiography Thomas J. Heffernan has suggested that religious literature itself 
achieved the same cult status as relics: reading the "sacred biographies" of saints was believed to offer spiritual benefits, and even the physical manuscripts themselves were thought to possess miraculous curative powers (Heffernan 36-7). The image of the passion, whether visual or verbal, assists the believer in recognizing the presence of the divine in the material world, and in grasping its meaning for the individual.

"Stond wel, moder" reminds us of the obvious but easilyoverlooked fact that literary artifacts do not exist in isolation, and suggests that the relation of texts to their cultural milieu can be quite dynamic. The poem sets up a debate between doctrine and experience, a debate which seems unresolved within the poem. Yet the questions it asks are not in fact unanswerable. The lyric's oppositions are clearly resolved by Christian history and culture. The poet may artfully exclude these from his poem, but he certainly knows them to be present in the reader's mind. To the extent that the reader shares Mary's grief and despair, he shares it only temporarily, during the brief imaginative moment that he inhabits the world of the poem. The reader's experience (as opposed to Mary's) is thus carefully circumscribed. It derives from Christian doctrine and also leads back to it. For all that "Stond wel, moder" seems to flirt with heterodox ideas, its meaning is actually quite determinate and stable. 
The literary historian can be reasonably assured that "Stond wel, moder" is not a subversive or satiric text simply because the Christian culture and tradition to which it is ancillary are so clearly documented. Its variation-on-a-theme constitutes an enrichment of that tradition, not a departure from it. The poet speaks as a member of a pre-established community of readers whose interests in literary pleasure are secondary to their spiritual concerns. In other words, however ambiguous the poem may be as an aesthetic construct, its place in the larger context of religious activity is clear.

When we turn to secular instances of pathos we find a somewhat different situation. My first example is the late fourteenth-century "Bird With Four Feathers," a "tretys of Parce michi domine" in the form of a lyric scene of pathos (reproduced as Appendix B to this chapter). The speaker relates how he walks out into the countryside one morning "disport to take," and discovers a bird, her feathers pulled, sitting in a briar and unable to fly away. When the speaker draws near and asks the cause of her sorrow, she replies:

Man, be In pees for cristes sake! 3if I schewe the min hertes will, Peynes sore me wolle awake; 3if thow wilt take my worde in mynde, Ther shal no sorow be my letting, That I nyl holy myn herte vnbynde, And sothly telle the thyn asking:-- 
Which were myn fedres pat were so clere, And who hath pulled hem alle fro me, And why I sitte singging on brere, Parce michi Domine.

What follows is approximately two hundred lines of moralization on the four feathers, which stand for youth, beauty, strength, and riches. The bird narrates how each of these qualities led her to folly and sin, and ruefully describes her loss of each in turn. She offers herself as an example of how "Alle that lyueth, bothe powre and ryche, / Shal deye vnknowyng of her day." In the final stanza the speaker, suitably sobered and apparently no longer in a mood to go a-Maying, kneels and "thanked this bryd of here gode lore."

My choice of this lyric as an example of the "secular" no doubt requires some defense, since clearly its themes and concerns are relentlessly anti-worldly. Indeed, one might argue that its emphasis on the propitiatory Latin prayer which "geteth godis pyte, / And scheweth to vs his blessed face" betrays the lyric's eschatological nature, and hence its intimate connection with Christian doctrine and worship. For all its spirituality, however, "The Bird With Four Feathers" lacks the iconic force of "Stond wel, moder." It does not, in other words, make divinity seem present to the reader: its voices are not those of God and his mother, but rather the generalized utterances of human nature still confined within the saeculum. Indeed, its very efficacy as 
an exemplum depends both on its unlocalized and fundamentally fictive situation, and also on a point of view which merely anticipates the soul's ultimate confrontation with the supra-mundane. In this sense it is secular as "Stond wel, moder" is not.

Its secularity and its difference from "Stond wel, moder" also appear in its construction. The fragmentary stanza-structure, together with the repetition at lines 171 and 209 of what appears to be an only partially-sustained internal refrain ("I was ful wilde, I am now tame") suggests some confusion in the composition or manuscript transmission of this lyric, and it may well be that the received text poorly reflects the author's intentions. In any case, the reader is struck by the poem's miscellaneous quality, and by how disjointedly its various elements fit together. The "dialogue" between sufferer and witness, for instance, frames the central planctus rather loosely: the speaker of the initial stanzas disappears entirely from the middle of the poem, and after line 90 the bird seems to have forgotten the presence of her earthly companion, and to be addressing God instead: "The myrrour, lord, deseyued me, / Wher-fore I aske, lord, of pi myght / Parce michi domine!" The persona of the bird herself is unevenly maintained in terms of both gender and estate. Though the stanza on her former beauty includes details most commonly associated with femininity ("My forhed large, my browes bent, / 
Myn ey3en cleer"), she later tells her interlocutor that "she" was once "man of muchel myght." The sins engendered by her strength and riches seem to alternate between brutal street crime ("Thei bat wolde not my heste fulfill, / My knyf was redy to his brest") and aristocratic display: "I lete me bilde castell and towres, / With-out I-warded with stronge dyche, / With-Inne Ibildet halles and bowres." The effect is to erode the particularities of the poem's opening characterization, as if all the many specific estates and ages of the danse macabre had been conflated into a single generalized voice. Finally, the biblical examples--Solomon, David, Nebuchadnezzar, and Job--are employed a bit erratically, since the first three are negative exempla of folly and the pride of life, while Job, by contrast, is adduced as an analogue to the speaker's newly-acquired humility. The final stanza disposes summarily of the fictional dialogue-frame, and concludes with the original speaker's encomium on the virtues of the word "parce," and of the prayer which forms the refrain of each stanza, and which is now revealed, according to the original rubric, as the lyric's real subject.

In some respects the disjunctions in "The Bird With Four Feathers" are not unlike those Wenzel finds in "Stond wel, moder," though perhaps they are less severe. The beast-fable device of the talking bird squares ill with the specifically human 
devotion of prayer, and the opening scene of mourning, with its promised expressions of unbridled grief, gives way to sober reflection on the vanity of human aspirations. In a sense, therefore, the lyric's dramatic context is potentially at odds with its doctrinal content. It is, I suppose, barely possible that the lyric is intended to satirize either the chanson d'aventure or the contemptus mundi tradition; the clue to the author's parodic intention, presumably, would be the sorts of incongruities we have already noted. If that possibility seems remote, however, it is no doubt because the poem's moral sentiments seem perfectly orthodox. The reader has no reason to think that the poem betrays anything but a straightforward and clumsy treatment of conventional materials.

Insofar as it employs a scene of pathos, and insofar as it depends for its intelligibility on certain extra-textual cultural assumptions, "The Bird With Four Feathers" resembles "Stond wel, moder." But it achieves its meaning by quite different means. Where "Stond wel" embroiders a a crucial moment in Christian history, "The Bird" arises from no such basis in fact. Instead it conjoins the fabular framework of the talking bird to a set of commonplace but ahistorical moral topoi. This difference from "Stond wel, moder" is crucial. If we are able to understand what the passion-lyric means, it is because that poem expresses not 
just the poet's imaginative vision, but also the determinate meanings of the sacred moment he dramatizes. But if "The Bird With Four Feathers" is poetically and intellectually coherent, it is above all because the poet has somehow made it so: he has selected its elements and reshaped them according to his own vision and fancy. ${ }^{1}$ One can easily imagine, as perhaps one cannot with "Stond wel, moder," that the whole assemblage might have been quite different. Certainly birds are traditional emblems for the human soul, and possibly the image of a featherless bird amid the briars dimly recalls the crucified Christ, yet there seems no organic reason for the poet's choice of a bird rather than (to seize upon a not-altogether-random alternative) a leech-gatherer. Thus the event dramatized in "Stond wel, moder" means, in a way nearly independent of the author's intentions, what Christian history requires it to mean. "The Bird With Four Feathers," on the other hand, means what the author intends it to mean. It is textual as "Stond wel" is not: its scene of pathos acquires sig-

1. The rather learned and "literary" quality of "The Bird With Four Feathers" is especially clear when we compare it with the analogous lyrics in Green's Early English Carols. (numbers 370, 378, and 389). These too are memento mori laments, but their extremely economical and ballad-like treatment of the narrator's encounter with a moralizing bird points up how thoroughly the author of "The Bird" has amplified his materials. 
nificance and exemplary force through the author's own inventive "weaving." Its rather clumsy concatenation allows us to see into its constitution as a secular artifact rather than a sacred icon.

My final example is well-known, and may be treated briefly; it is the Second Part of the Squire's Tale, in which Canacee encounters the lovelorn falcon. The similarities to "Stond wel, moder" and "The Bird With Four Feathers" are interesting, and perhaps not entirely fortuitous: a compassionate observer gazes upward at a sufferer whose earthly situation is presumably irremediable, and the heart of the scene is an exploration of the causes and significance of that suffering. But here, I would argue, there is simply no way to gauge the author's intentions with any certainty. Many recent readers of the Squire's Tale have claimed that the protagonists and their concerns betray so manifest a triviality that the scene must certainly be parodic. Certainly the amatory preoccupations of a Tartar princess and a talking bird pale beside the sorrows of Christ and his mother. But when we compare the Squire's Tale with "The Bird With Four Feathers" the case seems less clear. The formal resemblances between the dramatic situations in the two texts are quite striking, and the supposedly telling incongruities in the falcon's lament (her puzzling comparison of birds to birds, for instance) also appear in "The Bird With Four Feathers." 
Thus if we choose to regard "The Bird With Four Feathers" in the same skeptical light that has illuminated the Squire's Tale, it too can seem compromised. In its own way this lyric is, of course, supremely silly. Its homiletic effectiveness arises not from its dramatic situation, which unwittingly anticipates the calculated bathos of Gilbert and Sullivan's "Tit-Willow," but from its allegorized commentary, by means of which the poet clearly allies his lyric to the Ecclesiastes tradition of contemptus mundi and rueful complaint. The poem works--just barely so--because it relies on the shared moral assumptions of a cultural community which precedes, the more ad hoc community created by the imaginative experience of reading the poem. Hence for all its deficiencies of taste, "The Bird With Four Feathers" invests its scene of pathos with exemplary significance.

Canacee and her falcon, on the other hand, continue to perplex their modern readers. Our uncertainties, I would argue, are directly related to Chaucer's employment of a fictive, secular scene of pathos. Because no definitive sources for The Squire's Tale have been established, we are unable to examine (as we could for "Stond wel" and "The Bird With Four Feathers") the elements from which the tale is assembled. Our reading is further complicated by the strong possibility that the Canterburyframework renders the narrator himself unreliable. The episode 
betrays all the attributes of secular text, but somehow fails to supply crucial information about the strands that make up its web. One assumes that the author-behind-the-teller is in control of his narrative--that he means something by his spectacle of avian grief--but the episode seemingly occludes its affiliations with the extra-textual phenomena that might enable us to discern the "knotte why that every tale is toold" (CT V, 401). We don't, in other words, know what prior cultural community is assumed, and indeed, the central question in Squire's Tale studies seems to be what literary or social context, if any, is applicable. Possibly certain secular norms of aristocratic behavior and feeling are relevant, but no critic has satisfactorily demonstrated what Canacee and the falcon exemplify, or whether Chaucer intends his exemplum to be satiric or straightforward. One is almost tempted to conclude, on analogy with the later sentimental novel, that the Second Part of the Squire's Tale creates its own community of readers whose dispositions and judgments are formed not by the extra-textual norms of their actual cultural situation, but by the shared fictive experience of reading itself.

The Squire's Tale is an extreme case of pathos detached from the context which makes it intelligible. Its "free-floating" character makes it particularly resistant to interpretation. Most Chaucerian pathos, however, is amenable to analysis according to 
the two categories we have already established in our discussion of "Stond wel, moder" and "The Bird with Four Feathers": the sacred and the secular. These categories, I will argue, influence and even determine the style and potential significance of the works I will examine.

In 1963 Robert O. Payne defined the medieval ars poetica as "a process of arousing favorable response to a fittingly dignified statement of pre-existing truths" (Key of Remembrance 46). This statement helpfully defines the medieval poet's attitude towards his materials, and towards the literary tradition in which he works. It does not, however, remind us of the diverse modes in which this process may be embodied. A good deal of modern reading of medieval texts assumes the basic equality of all narratives--that they are "literary" insofar as they express the author's own creative transformation of represented events into a crafted fiction. This process operates universally, regardless of the poet's subject-matter, and in indeed what makes literature interesting to critics. Variations in decorum are mere surface features which can be explained with reference to historicallydetermined fashions or to certain generic traditions. Beneath this surface, however, lies a trans-historical conception of the poet's essentially transformative, creative project.

I will argue a contrary proposition, namely that for medie- 
val readers and writers some narratives are manifestly more authoritative than others, and often for reasons that have little to do with "literary" values. My own work stands upon Payne's shoulders, and attempts to get a clearer view of how decorum--the dignity and fittingness of a poetic statement--depends on the particular nature of the pre-existing truth to be conveyed.

The events represented in "Stond wel, moder" are presumed to be more real than those in "The Bird With Four Feathers." They have not just philosophical or moral value, or interest derived from the author's imaginative treatment of them, but a certain kind of cultural standing based on the fact that they are part of sacred history--the narrative which exists prior to the poet and his words, and whose author is God. Such materials possess a distinctive status, one which differs, as I shall argue, from the secular status assigned to non-Biblical history, and to fables like "The Bird With Four Feathers" or the Squire's Tale. In my analysis I shall insist that any critical assessment of Chaucer's tales of pathos depends on some understanding of such distinctions.

The basic distinction between sacred and secular narrative has to do with certain absolute differences between various classes of subject-matter. In the relatively pure instances I have examined in this chapter, those differing subject-matters call 
forth appropriate literary treatments which I have called "iconic" and "exemplary." It is, however, possible to view iconic and exemplary style as phenomena potentially separable from their customary subjects. One way to describe iconic style, for instance, is to note that the author is not required to defend the importance or value of his sacred subject-matter. He need only direct his poetic skills towards giving it an appropriate display. The exemplary author, by contrast, must establish the cultural importance and significance of his secular subject. His rhetorical skills are used to demonstrate his subject's relevance to the audience's concerns.

In the study that follows I will propose that the notions of sacred and secular subject-matter, and of iconic and exemplary style, can allow us to plot medieval texts along two axes of materia and dispositio. The scene of pathos is an ideal motif for this analysis simply because it occurs at every point along the axis of subject-matter, from the sacred suffering of Christ to the entirely secular suffering of Troilus or Cleopatra. The matrix created by these two axes allows us a more precise analysis of the tone of particular texts, since tone is the stylistic expression of the author's attitude towards his subject-matter. Above all it can help us to a clearer understanding of how and why so many of Chaucer's tales of pathos have been regarded as parodic, or as 
ironic reflections upon the personalities of their tellers. My own analysis will suggest that medieval storytelling virtually demands that an author have a repertoire of several voices and narrative dispositions, and that this, rather than an immediate assumption of the poet's satiric intent, should be the first factor to influence our reading of any particular tale.

Chapter Two will examine the Second Nun's Tale as an example of iconic narrative, and also as a classic instance of sacred pathos. The bulk of my discussion in this section concerns the status of the saint's legend. I will argue that hagiography as a genre has suffered from the misunderstanding of twentieth-century readers who no longer grasp its special relationship to Christian worship, and its peculiar representation of Christian history. Chaucer's tale shows certain individual variations from the norm, but chiefly it exemplifies both the matter and style of its genre. Chapters Three and Four examine the Man of Law's and Prioress's Tales, both of which are often described not merely as religious, but as vaguely hagiographical. I will argue that neither employs fully sacred subject-matter, and that neither treats its material in a fully iconic style. The subject of the Man of Law's Tale is non-Biblical chronicle history, and its less-than-canonical status requires the author to demonstrate its exemplary significance for Christian readers. The tale's 
rhetorical style, however, remains that of iconic narrative, and the effect of this hybridization is the subtle transformation of the heroine into something remarkably like the modern image of virtue in distress. The Prioress's Tale, I will argue, draws our attention to another sort of iconic style--not the verbal style of rhetoric, but rather the disposition of a cluster of narrative elements with potentially iconic significance. The tale's most interesting stylistic feature, however, is the way it suppresses or ignores those traditional and symbolic meanings in favor of a peculiarly secular and literal apprehension of its elements. Chapter Five takes up one of Chaucer's classicizing texts, the Legend of Good Women. That text's pagan, secular subject matter removes it from the realm of iconic narrative and makes it, like most treatments of classical material in the middle ages, fundamentally exemplary. Like the Second Nun's Tale, it offers a relatively pure instance of its narrative mode. Its rather labored effort to demonstrate the ethical relevance of its subject-matter, however, suggests the limitations of an extended exemplary treatment, and the risks involved in departing too far from received cultural norms. The style of the Legend, I will argue, embodies both the freedom and the liability of secular narrative. Chapter Six returns to the Squire's Tale, to the question of Chaucer's ironic intent here and elsewhere in the tales of pathos, and to a 
final estimate of his experiments in secular poetics.

Chaucer is universally acknowledged as a major literary

figure because of his innovative approach to language, and because of his interest in the dramatic possibilities of making narrative a vehicle for personal vision. The Canterbury Tales are a major experiment in all the various ways that stories can mean. At the same time, however, Chaucer retains his culture's rather conservative interest in narrative that serves cultural goals rather than individual vision or fancy. As H.R. Jauss puts it, in Christian rhetoric "the exemplary was opposed to the imaginary, pity leading to action was opposed to purgation by catharsis, the hortatory principle of emulation was opposed to the aesthetic pleasure derived from imitation" (Jauss 289). My study will show that Chaucer retains these convictions about the pragmatic and public aims of literature even as he extends the mimetic and affective possibilities of English poetic language. It is my hope that an examination of Chaucer's tales of pathos will contribute not just to our interpretation of individual poems, but to a fuller estimate of how Chaucer's innovations arise from (and finally, as I will argue, lead back to) his culture's understanding of narrative significance. 
Appendix A

'Stond wel, moder, vnder rode, bihold pi child wyth glade mode, blybe moder mittu ben.'

'Svne, quu may blipe stonden? hi se pin fet, hi se pin honden, nayled to be harde tre.'

'Moder, do wey pi wepinge;

hi bole pis ded for mannes thinge-for owen gilte poli non.'

'Svne, hi fele be dede stunde; be swerd is at min herte grunde, pat me byhytte symeon.'

'Moder, reu vpon bi bern! bu wasse awey bo blodi teren. it don me werse pan mi ded.' 'Sune, hu mitti teres wernen? hy se bo blodi flodes hernen huth of pin herte to min fet.'

'Moder, nu y may be seyn, bettere is pat ic one deye, ban al man-kyn to helle go.' 'Sune, y se pi bodi swngen, pi brest, pin hond, bi fot pur-stungen-no selli bou me be wo.'

'Moder, if i dar pe tellen, yif $y$ ne deye bou gost to helle; hi bole bis ded for bine sake.' 'Sune, bu best me so minde; with me nout; it is mi kinde pat $y$ for be sorye make.'

'Moder, merci! let me deyen, for adam ut of helle beyn, and al mankin bat is for-loren.' 'Sune, wat sal me to rede? pi pine pined me to dede, let me deyn bi bi-foren.'

'Moder, mitarst bu mith leren wat pine polen bat childre beren 
wat sorwe hauen pat child for-gon.'

'Sune, y wot y kan be tellen, bute it be pe pine of helle more sorwe ne woth y non.'

'Moder, reu of moder kare! nu bu wost of moder fare, bou bu be clene mayden man.' 'Sune, help alle at nede, alle bo bat to me greden-mayden, wyf and fol wyman.'

'Moder, y may no lenger duellen, be time is cumen y fare to helle be pridde day y rise upon.' 'Sune, y wyle wi'the funden, $y$ deye $y w i s$ of pine wnden, so reuful ded was neuere non.'

When he ros ban fel pi sorwe, pe blisse sprong pe pridde morewe, wen blipe moder wer pu bo.

Moder, for pat ilke blisse, biseche vre god, vre sinnes lesse, bu be hure chel ayen hure fo.

Blisced be pu, quen of heuene, bring us ut of helle leuene purth bi dere sunes mith. Moder, for bat hithe blode bat he sadde vpon pe rode, led us in-to heuene lith. AmeN

(MS. Digby 86; Brown, 13 th Century, \#49A)

\section{APPENDIX B}

Here bygynnith the tretys of Parce michi domine

By a forest syde walking, as I went Disport to take In o mornyng, A place I fond, schaded with bowes ybent, Iset a-boute with flowrs so swete smellyng I leyde me down vpon that grene, And kast myn ey $3 e n$ me aboute: 
I fond there breddes with fedres schene, Many on sitting vpon a rowte.

O brid per-by sat on a brere,

Hir fedres were pulled, sche myght not fle;

She sat and song with mornynge chere, Parce michi domine.

'Spare me, lord, kyng of pytee,'

Thus sang pis bryd in pover array. 'My myrth is goo \& my Iolyte;

I may not flee as othir may,

My fedres schene ben pulled me fro;

My 3owth, my strengthe, \& my bewte,

Wher-thorgh I take pis song me too:

Parce michi domine.'

When I herd pis mornyng song, I drew pis brid nere and nere, And asked who had done pis wrong And brought here in so drowpyng chere, And who had pulled here fedres away That schuld here bere fro tre to tre, And why sche song in her lay, Parce michi domine.

The brid answerd and seid me till: 'Man, be In pees for cristes sake! 3if I schewe the min hertes will, Peynes sore me wolle awake;

3if thow wilt take my word in mynde, Ther shal no sorow be my letting, That I nyl holy myn herte vnbynde, And sothly telle the thyn asking:--

Which were myn fedres bat were so clere, And who hath pulled hem alle fro me, And why I sitte singging on brere, Parce michi Domine.

'Fedres fowre I had ywis, The two were set on euery wynge;

Thei bare me breme to my blys,

Where me lust be at my lykyng:

The first was 3owthe, be secunde bewte, Strengthe and ryches pe other two; And now bei ben, as thow maist se, Alle foure fedres Ifalle me fro. 
My principal fedre 3owthe it was, He bare me ofte to nysete,

Wherfore my song is now "allas! Parce michi Domine!"

In 3owthe I wrowth folies fele, my herte was set so hye in pride; To synne I 3af me euery dele, Spared I neither tyme ne tyde; I was redy to make debate, my lyf stood ofte in mochel drede; And my lykyng, to walke late, And haue my lust of synful dede: I was now here, I was now there, Vnstable I was In al degre,--

To him I crye pat marie bare, Parce michi domine!

'For Salamon seith in his poyse, Thre weyes ther beth ful hard to knowe: Oon is a schep bat sailleth in the see, An Egle in hey, a worm in lowe; And of be ferth, telle he ne can, It is so wondirful in his hering-The weyes of a 3ong man, Which bat ben here at her lyking. And now hath age Ismyte me fro My pryncypal fedre of Iolyte;

For al pat euer I haue misdoo, Parce michi domine!

'My Secunde fedre heith bewte; I held my self so clere of schap, That al the peple scholde loke on me, And worschip me with hoode \& cap;

'My rud was reed, my colour clere, me bought neuer non so faire as I

In al a contre, feer no nere, In fetewrs \& schap so comely, My forhed large, my browes bent, Myn ey3en cleer, and corage bolde; My schap ne myght no man ament, Me thought my self so fayre to be-holde. And 3et I was begyled in syght, The myrrour, lord, deseyued me, 
Wher-for I aske, lord, of pi myght Parce michi domine!

'This fedir bare me ful ofte to synne, And principally to leccherye;

Clipping and kessing cowth I not blynne, me thought it craft of curteseye.

A cusse it is be deuel-is gynne,

Oft of it ariseth woo \& wrake;

The deuel with cusse many doth wynne, I counseil the thow synne forsake.

Sampsoun lost his strengthe per fore, Dauid his grace for Bersabee, Til he cried with wordes sore, Parce michi domine!

'Salamon, pat worthy king,

Ful fayr he was from top to too;

Wher-fore in his age 3yng,

He was amabilis domino;

And after he fel fowle \& sore,

For lust of women pat was him neygh;

Thei fonned him in his age hore,

That he forsoke his god on heygh.

'Nought onlich pise but many moo, bewte hath be-giled I-wys:

I woot wel I am on of thoo,

I can pi better telle pis.

Now hath age y-smyte me fro

My Secunde Fedre, pat height bewte;

For al bat euer I haue misdoo,

Parce michi domine!

'My thridde fedre strengthe height; My name was knowe on euery syde, For I was man of mochel myght, And many on spak of me ful wide: To prike and praunce I was ful preste, My strengthe to kepe In euery place; And euer more I had the beest-Such was my hap, such was my grace. My strengthe ful ofte me drowgh amys, And torned me, lord, clene fro the;

Now kyng corowned In heuenne blys, Parce michi domine! 
'This fedre me bare be-3onde the see,

To gete me name In vncowthe londe,

To robbe and slee had I deyntee,

$\mathrm{Ne}$ spared I neither fre ne bonde;

of holy chirche took I no 3eme,

Bokes to take ne vestement;

Ther myght no ping so moche me queme

As robbe, or see an abbey brent.

With strengthe I gat me gret aray,

Precious clothes, gold, and fee:

I thougth ful litel on thilke day--

\section{Parce michi domine!}

'When Nabugodonosor, fers in fight, Ierusalem had thought to wynne;

And so he dede with mayn \& myght, And brent be temples bat were ber Inne;

And al the gold bat he there founde

He toke with him and hom gan ryde;

Him thought per schold no ping withstonde.

His herte was set so heigh In Pryde:

Til be king of myghtes most

Browght him pere pat lowest was,

And caught him fro his real oost,

And drof him to a wildirnesse;

And there he lyued with erbe \& rote,

Walkyng euer on foot \& on honde,

Til god of mercy dede him bote,

And his prison out of bonde:

Thanne seide pis kyng thise wordes, Iwis:

"Al thing be, lord, at thi powste,

Mercy I crie; I haue do mys--

Parce michi domine!"

'While I had my strengthe at will, Ful many a man I dede vnrest;

Thei bat wolde not my heste fulfill,

My knyf was redy to his brest;

And now I sitte here blynde and lame,

And croked beth my lymes alle.

I was ful wilde, I am now tame;

This Fedre of strengthe is fro me falle;

And now hath age ysmyte me fro

My thridde fedre of Iolyte:

For al bat euer I haue misdo, 


\section{Parce michi domine!}

'My ferthe feder ryches was;

To make it schyne I trauailled sore,

'I went in many a perilous place, Wel oft my lyf was neigh for-lore; By dale, by downe, by wode syde, I bood many a bitter schowr; In salt see I sailled wel wide, For to multiplie my tresowr: With fals sleightes I gat my gode, In couetise I grownded me,-Ihesus, for this precious blood, Parce michi domine!

'Whan I was siker of gold ynow, I gan to ride a-boute wel fast; I purchaced moche, \& god wot how; I wende pis lyf wold euer haue last; I let me bilde castell and towres, With-out I-warded with stronge dych, With-Inne I-bildet halles and bowres. Ther was no tow $r$ my castel liche, In this was yset al my lyking, And turned me, lord, holich from the-To the I crye now, heuen king, Parce michi domine!

'Whan I was most in al my flours, and had aboute me wif and childe, I lost my catel and my tours; Thanne wex my herte in party mylde; Catell fel fro me sodeynly, Ryght as it come it went away: men seith, good gete vntrewely, the thridde heire broke it ne may. I was ful wilde, I am now tame; fortune hath pulled ryches me fro: 3owre wrecche, lord, I can not blame-Parce michi domine!

'Iob was richer panne euer was I, of gold, siluer, \& other good; it fel hym fro, and pat scharply 
As dede be water owt of the flood;

Hym was not left so mochel a clothe

his naked body for to hille;

Hym lakked crosted of a loffe,

When him leste ete In tyme of mele:

And 3et he held vp thanne his honde,

And seide, "heigh god in mageste,

I thank the of thy $s$ wete sonde!

Parce michi domine!"

'Now parce michi domine!

My loye, my merth, is al agoon;

3owth, Strengthe, and my bewte,

My fetheres faire, be falle me froo.

Wher-to is a man more liche

banne to a flowr pat springis In may?

Alle that lyueth, both powre and ryche,

Shal deye vnknowyng of her day.

I sette me down vp-on my knee,

And thanked this bryd of here gode lore;

It thought me wele this word 'Parce'

Was bale and bote of gostly sore.

Now parce, lord, and spare thow me!

This is a word pat sone gat grace,

And 'Parce' geteth godis pyte,

And scheweth to vs his blessed face. Amen.

(MS. Bodley 596; Brown, IVth Cent, 非21) 
CHAPTER TWO

\author{
"AFTER THE LEGEND IN TRANSLACIOUN": \\ HAGIOGRAPHIC DECORUM IN THE SECOND NUN'S TALE
}

The Second Nun's Tale is not a favorite Chaucerian text. Its sensibility--austere, assured, cool as Cecilia herself in the bath of flames--is disconcerting. Its teller is the least distinct of pilgrims, and she speaks with none of the sort of problematizing self-consciousness so prominent elsewhere in the Canterbury Tales. The Second Nun's Tale belongs to a genre long out of fashion, and presents itself as a workmanlike, conservative, utterly typical representative of that genre. There seems to be little to be said about it. As Carolyn Colette neatly puts it, it is "a tale in search of a critical subject" ("Critical Approaches" 101).

At the same time, however, the Second Nun's Tale is central to a study of Chaucerian pathos simply because its form--like that of every saint's passio--is a scene of pathos. That scene is not, granted, accompanied by the sort of the sort of emotional expansiveness we associate with the Man of Law or the Prioress, and that very fact deserves consideration. In this chapter I will attempt to define the particular quality and function of pathos in 
the Second Nun's Tale. Like most previous readers of the tale, I will take its conventionality as a given. Unlike most previous readers, I hope to offer an adequate apologia for that conventionality. I will argue that while the tale may indeed be an early work, it is not an apprentice-piece. Rather it is a rare and valuable instance of Chaucer's contribution to an important medieval mode of iconic narrative. The tale's very lack of idiosyncrasy is crucial: it enables the literary historian to observe Chaucer's participation in certain traditional and normative strategies for representing meaningful suffering.

The saint's legend is, of course, a subject no less broad and various than sainthood itself. The close connection between cultural institution and literary genre is apparent in the ambiguous nature of the very term "hagiography," which can mean either the study of saints in general, or the literary corpus which documents and celebrates such persons (the sense in which I will use the term here). Indeed, the textual tradition is closely linked to the wider cultural phenomenon of the veneration of saints themselves: one of the first steps in the official transformation of a newly-defunct holy figure into the full-fledged object of cultus is the composition of a legend which serves partly commemorative and partly polemical aims. In a very real sense, then, the literary form of a legend derives from its function, and 
its legitimacy as a text depends on the legitimacy of the goals it serves.

Insofar as works of hagiography serve a no-longer-current conception of sainthood, they have suffered the typical fate of narratives which outlast the cultural institutions from which they spring: the slow decline from prestige and efficacy to that more attenuated form of appeal summed up in the epithet "charming." Saints' legends have come to seem quaint or escapist because their cultural context has become distant and diminished. What follows is an attempt to undo some of the effects this process has had upon the modern assessment of medieval hagiography. The information I present concerning the cult of saints is well-known to historians, but is not sufficiently familiar to literary critics eager to treat saints' legends as if they were--like fabliaux or romances--merely another form of narrative.

What often seems to distinguish hagiography from other forms of medieval narrative is a particular convergence of miracles, mayhem, and melodrama. For modern Anglo-American critics the great mystery surrounding hagiography has been the enduring popularity of these motifs. As Robert Frank somewhat wickedly notes, the events in Chaucer's own hagiographic tales bear a certain superficial resemblance to the bizarre situations celebrated in tabloid headlines ("CHILD LIVES AFTER THROAT CUT, 
SINGS!" ["Pathos" 49]). Our association of such journalism with a certain kind of reader--an "inquiring mind" animated by insatiable, vulgar curiosity about all possible forms of sheer weirdness--has certainly affected our historical understanding of medieval saints' legends. How could hagiographers pretend that their fantastic narratives conveyed the truth of Christian history? How could any but the most wretchedly ignorant and credulous audiences find themselves both instructed and delighted by texts that seem to express little more than morbid fixations on ritual violence and extravagant prodigies?

I would argue that these sorts of scruples, though they apparently reflect an entirely natural and universal skepticism and disdain for popular ignorance, find their real origin in a critical presupposition that is neither aesthetic nor scientific. The key factor in our lessened appreciation of saints' legends is in fact the altered status of the cult of saints itself. Since the Reformation and Counter-reformation, students of hagiography have emphasized the role of sainthood as an image of perfected human nature. Whatever the doctrinal view of the saint's power to intercede on behalf of the faithful, his or her major value is exemplary, and the key pastoral function of hagiography is to provide compelling role models for the faithful. John Foxe's statement in Actes and Monuments is typical of this view: 
In these men we have an assured and plaine witnes of God, in whose lyfe appeared a certaine force of divine nature, and in their death a farre greater signification. . . To be shorte, they declare to the worlde what true fortitude is, and a waye to conquer, which standeth not in the power of man, but in hope of the resurrection to come, and is now I trust at hand. (cited in White 167)

As Foxe's careful qualification concerning fortitude "which standeth not in the power of man" suggests, this version of sainthood does not deny the role of divine intervention. It does, however, emphasize the martyr's privilege as an example of how faith and grace may bolster mortal endeavor and show us "a waye to conquer." The legend thus becomes a kind of historical anecdote concerning a particular human being's heroic virtue. This view, I will argue, is not much help in understanding medieval hagiography.

If the saint is an imitable (albeit extraordinary) model of virtue, then students of his or her life will naturally value the circumstantial and the verisimilar. Miraculous, fantastic, or sensational elements, insofar as they distance the narrative from recognizable probability, are by definition suspect. The great Bollandist historian Hippolyte Delehaye eloquently articulates these modern assumptions about hagiographic authenticity even as he reviles the sophistications he finds so typical of late classical and medieval legends. Of the interrogatory of the martyr he says this: 
It is very rare that from among the questions and answers one can seize any personal and characteristic trait. We find only dissertations on the absurdity of paganism and the beauty of the Christian faith, speeches of an inconceivable improbability which would be more appropriate on the lips of a pulpit orator than on those of a prisoner before a court of justice in the course of a rapid criminal procedure. The triumphant eloquence of the martyr is usually set off against the ignorance and vulgarity of the judge, unless indeed the latter displays sufficient knowledge of the Scriptures and the Christian religion to provoke some learned reply from the accused. . . . To anyone who has studied the authentic Acts of the martyrs it is superfluous to point out how falsely such rhetoric rings, and what a difference there is between the short and touching answers of the martyrs inspired by the wisdom of the Holy Ghost, and these studied declamations which at their best recall some school display. (Delehaye 94-5)

As a scholar and as a believer Delehaye is offended by the spectacle of living human heroism buried under the unnecessary debris of decadent rhetoric. And just as the words of the martyr are falsely elaborated in quest of illegitimate literary effects, so his deeds are debased by the medieval hagiographers' tendency to multiply his [the saint's] sufferings without having to trouble themselves as to the limits of human endurance, for Divine Providence is made to intervene to prevent the saint from succumbing beneath the agony inflicted, and to allow the hagiographer to exhaust all the torments that his imagination or reminiscences from his studies may suggest. (Delehaye 95)

Delehaye blames the superabundance of prodigies on "the blind attraction of the populace for the miraculous and the sensibly supernatural," whereby "the mysterious colloquies of the soul 
with God must be translated into palpable results in order to produce any impression on the popular mind" (Delehaye 49-50). In practice this empirical approach to hagiography does a good deal to illuminate Church history, but it does remarkably little to recover the "true meaning" of sanctity in either historical or universal terms. In The Legends of the Saints Delehaye sketches a method for distinguishing hagiographical fancy from historical fact. His account of the various ways hagiographers have elaborated, conflated, falsified, and confused their sources is deeply learned and of undisputed scholarly interest. It is also animated by boundless exasperation at the well-meant but irremediable damage hagiography has done to our knowledge of the early martyrs: "the saints run a continual risk of being compromised by the literature written in their honor" (Delehaye 215). His irritation at the shoddy historical methods employed by hagiographers here converges with his sense that matters of faith are also at stake. A rational inquiry into sainthood should, he argues, allow us "to appraise at their true value the documents which justify our attitude of veneration" (Delehaye $x$ ). Delehaye regularly contrasts the fabulous accretions of traditional hagiography with the compelling, "simple" truth of historical martyrdom. A more exacting approach to the facts of sainthood should also satisfy the devot's longing for a closer approach to its spiritual 
sig nificance.

Chapter $\mathbf{V}$ of The Legends of the Saints is a tour de force analysis of the various legends of St. Procopius. Delehaye zestfully demonstrates the process whereby the facts of an actual martyrdom have been bloated, distorted, and otherwise rendered meaningless by the addition of incredible miracles, fanciful amplifications, and pompous rhetoric. Where in all this rigamarole, he seems to ask, is the saint himself? After showing that virtually none of the lore surrounding Procopius stands the test of historical scrutiny, Delehaye concludes thus: "The historic residue is this: a Christian named Procopius, a native of Jerusalem, was martyred under Diocletian by order of the judge Flavianus, and suffered by the sword" (Delehaye 145). The slightly disappointing nature of this conclusion deserves comment. It tells us that a certain man died in a certain fashion. It tells us nothing about what marks this man's life or death as sanctified, or about what might justify his public veneration. The same meagerness of result appears in Delehaye's rational inquiry into early cult practices: to document that they existed is not to reveal anything about their value.

Delehaye's own prefatory remarks on the spiritual benefits to be derived from greater and more exact historical knowledge of sanctity are noteworthy, for they reveal what seems to be missing 
from the fruits of his later analysis:

It may, perhaps, be as well to warn the reader from the first against an impression that might be gathered from a study which is mainly devoted to the weak points of hagiographic literature.

To give assistance in detecting materials of inferior workmanship is not to deny the excellence of what remains, and it is to the ultimate advantage of the harvest to point out the tares that have sometimes become mingled with the wheat to a most disconcerting extent.

The simple narrative of heroic days, written, as it were, with pens dipped in the blood of martyrs, the naive histories, sweet with the perfume of true piety, in which eye-witnesses relate the trials of virgins and of ascetics, deserve our fullest admiration and respect. (Delehaye $\mathrm{x}-\mathrm{xi}$ )

The visionary quality of this statement is poignant. It suggests that historical study should reveal, in truer and more authentic form, the intensely physical, charismatic, and vibrant personality of the saint. Yet in describing the condition of knowledge to which his program aspires, he employs the very figures of rhetoric which he will elsewhere deplore: the reader's "harvest," the hagiographers' "pens dipped in the blood of martyrs," and the sweet "perfume" of sanctity. Delehaye's remarks here may usefully be juxtaposed with a passage from Walter Daniel's twelfthcentury Epistola ad Mauricium, in which the author answers the objection that the miracles described in his Vita Sancti Aelredi--miracles to which he himself was eyewitness--strain credulity: "Is it supposed that the dead body of Aelred did not 
shine when it was washed? It was a light to all of us who stood by" (ed. and tr. F.M. Powicke; cited in Heffernan 109). The miracle resides not in Aelred's corpse, but in the heightened perceptions of those standing round it, perceptions communicable only in the language of poetic hyperbole. Both Delehaye and Walter attest to the profoundly figural quality of sanctity; the saint's meaning resides not in his "historic residue," but in his transforming effect on those who witness his presence, an effect expressed by the believer's "as it were."

An attempt to account for the "as it were" quality of saints' legends--and one that has had considerable influence on their literary assessment--is the supposition that the miraculous and sensational elements in hagiography are properly understood as fictive devices. Like fables, legends convey higher truths by means of an integumentum. Proponents of this approach, however, insofar as they still retain the notion that saints ought to provide us with role models, are often at a loss to explain why hagiographers have not chosen more accessible and more ethically intelligible wrappings for their pious fictions. In her study of Jacobus de Voragine's Legenda Aurea, for instance, Sherry Reames unquestioningly adopts the Reformation and Renaissancehumanist view of hagiography as anecdote, and regards medieval hagiography as indifferent to historical probability, crudely literal 
in its depiction of spirituality, rhetorically insincere, and hence potentially corrupting rather than edifying. Jacobus' interest in spectacle and the supernatural is no mere harmless embellishment to traditional tales of human sanctity: "Rather a strong case might be made for the hypothesis that the Legenda persuaded susceptible believers to adopt a number of habits and beliefs that were 'superstitious' in the sense of being at odds with a rational, well-balanced understanding of the faith" (Reames, Legenda Aurea 208-9). She does acknowledge that Jacobus' collection is designed to serve the professional and institutional needs of the Dominicans, but finally she attributes the legends' characteristic presentation of the saint as a superhuman wonder-worker to a kind of monumental bad faith: Jacobus pursues the Church's shortsighted wish to consolidate its spiritual control, while neglecting the more universal demands of pastoral care. "As Delehaye has reminded us," she states,

much can be forgiven medieval hagiography when the deeds it celebrates are shining examples of kindness, self-sacrifice, and generosity to those in need. But to my knowledge no authority on the genre has endorsed the kind of hagiography which ignores those ideals and celebrates power in their place. (Reames, Legenda Aurea, 89)

What this statement ignores, of course, is the essentially revisionist perspective of Delehaye and the entire Bollandist enterprise, which has sought to extract what is historically veri- 
fiable (and hence of value to scholars) from centuries of extraneous fancy and superstition. What she also overlooks is the degree to which the very existence of the Bollandists reflects a significant shift away from the medieval conception of how and why sainthood should matter to the Christian. The sort of misapprehension that Reames represents is more than just a failure of historical imagination. To assume a universal and "true" value for sainthood (in her case evidently what twentieth-century American intellectuals might find ethically normative in the living deeds of long-dead Christians) is not only to distort the "background" against which literary historians read works like the Legenda Aurea; it is also to obscure the fundamental status of the genre itself.

No account of medieval hagiography can afford to discount its emphasis on miracles, or its presentation of the saint as thaumaturge. To treat the "irrational" elements in hagiography as a credulous or cynical subversion of the saint's "real" value as a role-model is to reduce these texts to mere exempla--and feeble exempla at that. It will be more profitable to regard saints' legends as legitimate instances of what Rgis Boyer has called "texts which never live a life of their own, texts which are mastered, orientated, which exist only in accordance with an ideology" (Boyer 35; similarly Boureau). That ideology is of 
course the Christian cult, and insofar as the literary and imaginative experience of reading and writing hagiography arises from and leads back to the realm of public worship, the saint's legend is a classic example of an iconic text. There is, moreover, a good deal of evidence to suggest that the central purpose of most medieval hagiography was nothing more nor less than the celebration of power: the power of God, the power of the saints in heaven, and the power of the Church on earth.

Prime evidence for this claim lies in the very superabundance of miracles that excites the suspicion of readers like Reames. Even a brief glance at the work of Benedicta Ward, Patrick Geary, Ronald Finucane, or Andr Vauchez shows how strongly the veneration of saints in the Middle Ages was predicated on the belief that the saint exercised special powers which were both the reward for and the manifestation of extraordinary divine favor. The expectation of miracles (and even, as Geary has shown, the attempt to extort them) in return for the devotion of living souls is entirely too widespread to be merely vulgar or popular. The commercial benefits and civic self-esteem enjoyed by any town or religious foundation lucky enough to find itself at the center of a cult are well-known, as were the political advantages available to clans or dynasties under the protection of a powerful saint, the most famous example being the connection 
between the cult of St. Denis and the consolidation of the Capetian monarchy. Indeed, Vauchez suggests that the relatively small number of monastic saints declared in the high Middle Ages, at a time when papal canonization could guarantee international glory and devotion, is due to the disruptive inconveniences of providing large numbers of faithful outsiders with access to the cloistered saint's wonder-working relics (Vauchez 377-8). The miraculous events surrounding relics and pilgrimage sites, though the target of contemporary skepticism concerning abuses, are not per se called into question until the Lollard criticisms of the later Middle Ages (see Jones for a survey of orthodox defenses of saints' images). There is no doubt plenty of justification for regarding faith in saintly miracles as a superstitious folk-encroachment on the Church's proper spiritual tasks. But given its prevalence (to say nothing of the reluctance with which it was relinquished at the Reformation), it would be strange indeed if it found no reflection in hagiography, and if that reflection were not a powerful indicator of its cultural significance.

In light of this mass of cultural evidence, the claim that miracles and prodigies are irrelevant to the central exemplary purpose of medieval hagiography seems less secure. It is further weakened by the fact that the hagiographers themselves, whenever they state their purposes, declare a variety of goals in addi- 
tion to the presentation of saintly models for behavior. Jacques de Vitry, for instance, in the Prologue to his life of Mary of Oignies, states that those who "put down in writing the virtues and the works of the saints who went before for the use of those coming after them" do so in the hope that they might "strengthen the faith of the weak, instruct the unlearned, incite the sluggish, stir up the devout to imitation, and confute the rebellious and the unfaithful" (de Vitry 1). Similarly, Bishop Peter Baone of Treviso hopes his life of Henry of Bolzano will serve "to honor the saints, and to arouse grief among infidels, envy in the nonbeliever, and distress among the undisciplined; while the Devil groans, joy is generated among the faithful of Christ" (Acta Sanctorum, cited in Goodich, Vita Perfecta 65). The mere variety of expected effects should suggest the relative unimportance of the saint as a simple behavioral model for Christian auditors, while the references to the consternation of the heathen certainly imply that the legends celebrate the spiritual and political advantages of belonging to a winning team. Indeed, as actual sainthood in the late Middle Ages came to be more and more associated with heroic ascesis and the battle against mundane temptations, the audience for saints' legends needed to be reminded all the more strongly of the hagiographer's real purpose. Jacques de Vitry accompanies his narrative of Mary of Oignies' youthful self- 
discipline with the following caution:

I do not say this to commend the excess but so that I might show her fervour. In these and in many other things wherein the privilege of grace operated, let the discreet reader pay attention that what is a privilege for a few does not make a common law. Let us imitate her virtues, but we cannot imitate the works of her virtues without individual privilege. . . . Thus what we have read about the things which certain saints have done through the familiar counsel of the Holy Spirit, let us rather admire than imitate. (de Vitry 14-15)

For this very reason Donald Weinstein and Rudolph Bell call their analysis of sainthood a study of Christianity's "two worlds": the qualities for which holy persons were revered came to have fewer and fewer points of resemblance to the piety of their devots, even in its least debased and superstitious forms.

The expectation that true hagiography should preserve both verisimilitude and imitableness must inevitably founder upon the representation of the saint's torments. One of Delehaye's objections to traditional hagiography is that the passio includes so little depiction of true pain. Indeed, the medieval hagiographer seems to regard sanctity as inseparable from an astonishing imperviousness to threats and torture. The attitude towards the saint's impassibility is, like the attitude towards miracles, a key index to the difference between medieval and modern constructions of sainthood. Foxe's reports of English Protestant martyrs clearly imply that these victims do indeed feel pain, and that 
their capacity to endure and even glory in it offers not just a divine indication of the justness of their cause, but also a moral standard to which all should aspire. To deny the martyr's pain is to efface the final triumph of the human virtues which singularized him or her in the first place.

This attitude towards impassibility might well have seemed disrespectful to earlier generations of Christians, who looked to saints not for an image of perfected human nature, but rather for miraculous proofs of God's capacity to preserve certain mortals and to glorify them as superhuman conduits of divine power. As Peter Brown notes, the believer's wonder at saintly impassibility animates even the earliest stages of the cult of saints:

The original death of the martyr, and even the long, drawn-out dying of the confessor and the ascetic, was vibrant with the miraculous suppression of suffering. . . The explicit image of the martyr was of a person who enjoyed the repose of Paradise and whose body was even now touched by the final rest of the resurrection. Yet behind the now-tranquil face of the martyr there lay potent memories of a process by which a body shattered by drawn-out pain had been enabled by God's power to retain its integrity. (Brown 80)

The saint's legend thus testifies not simply to a particular individual's immovable commitment to the faith, but more importantly to God's power to reward such faith with miraculous resistance to pain and terror, a physical inviolability which mirrors the perfect wholeness of the saint's belief. This frankly theo- 
phanic image of holiness certainly seeks to inspire the believer; but it can scarcely offer itself as an object of imitation.

What bridges the gap between divine and human nature is, of course, the institutional cult, which defines the relationship of devot to saint as supplicatory rather than imitative. This notion appears in the medieval treatment of a group of related versions of the passio of St. Margaret. Her dying prayer, at the moment when narrative trajectory demands that she articulate the essence of what her experience means, is that she be granted intercessory power in favor of those that come after; in the South English Legendary she enumerates these powers in an interestingly anachronistic survey of medieval devotional practices:

Grante me ich bidde pe . for bin wonden viue pat 3if enimon hap gode munde. Louerd of min liue And of pe pine pat ich habbe ipoled. for pine grace Oper writ in god entente . and ret in eni place 3if hi biddep in god entente. grante hom milce \& ore 3if hi in eny anuy beop . bring hom out of sore 3if enymon in onur of me . eny chapel dep rere Oper eni weued in churche. oper eni li3t find pere In onur of me up is coust. Louerd bidde ich pe 3if he biddep ping pat is to bidde. grante hom for pe loue of me

And 3if any womman to me clupep . in trauail of childe Oper bifor my lif rede. Louerd beo hure milde Ne lete hure no3t perewip spille . ac bring pat child to si3te And al sauf of is moder wombe. wip al is limes ri3te (South English Legendary, St. Margaret, 273-86)

This oddly discursive insertion occurs in the Legenda Aurea, the South English Legendary, Mirk's Festial, Bokenham's Legendys of 
Hooly Wummen, and Caxton's Golden Legend. Its effect is as resolutely opposed to the illusionism we expect of narrative as it is inimical to the accuracy we expect of history; yet the authors, adaptors, and compilers of the legend were perfectly willing to rupture verisimilitude in the interest of spinning connections with significant extra-narrative concerns and activities.

It would of course be very inaccurate to suggest that medieval hagiography neglected ethical teaching in favor of the mere reinforcement of ritual behavior. We ought, however, to recognize that hagiography rarely serves as the primary vehicle of that teaching. While saints' legends do not exclude the positing of ethical models, they proclaim their greater concern with more obviously corporate goals: they educate the audience about the feasts of the liturgical calendar and about the deeds of past Christians, they encourage faith in the intercessory power of the saints, they reinforce the cult activities surrounding particular saints, relics, and religious foundations, and they celebrate God's power to preserve his chosen ones and to confute his enemies. The private, contemplative pleasures of reading and storytelling are meant to reinforce participation in public, corporate practices. However vivid and powerful the legend's narrative images, its aesthetic qualities properly subordinate themselves to other goals. Let us now turn to some specific literary manifestations of 
sainthood. Stories about saints of course present a considerable spectrum of types. The scenario most useful for my purposes, however, is the female saint's passio. This familiar narrative springs from the refusal of a virtuous woman to compromise her Christian devotion by capitulating to illegitimate authority. The demand for her obedience may be civil or parental, and often assumes the form of a threatened sexual violation. Her resistance catapults the saint into a sequence, often rendered in sensational detail, of punishment, torture, dismemberment, and eventual death. This ordeal is attended by miracles and prodigies, and throughout it God's power sustains the saint, enabling her to resist pain, defy her persecutors, and convert those around her. The bestknown instances of this scenario are such classical virgin-martyrs as Margaret, Catherine, and Agnes. The texts from which I have drawn my characterizations are the thirteenth-century Legenda Aurea by the Dominican Jacobus de Voragine (c. 1275; probably the most celebrated and influential collection of medieval legends), and some of its English vernacular progeny: the South English. Legendary (first quarter of the fourteenth century), Mirk's Festial (c. 1400), Osbern Bokenham's Legendys of Hooly Wummen (1443-47), and Caxton's Golden Legend (1483). Throughout these various versions the features of individual legends remain remarkably constant. 
Clearly the narrative type I've described is formally a scene of pathos. Through her victimization the humble protagonist is exalted. Power reversal is, indeed, the dominant pattern in hagiography, especially in the depiction of female saints. Characteristically the virgin-martyr rejects the socially-approved roles of wife, mother, and law-abiding citizen, and just as typically she violates the cultural expectations for deference and timorousness on the part of women and girls. (St. Margaret's dragon, finding itself pinned to the ground, with the saint's foot on its neck in the traditional gesture of conquest, petulantly observes that "maidens ssolde be[o] . fol of milce and ore" [SEL, St. Margaret, 229]). The warrant for such disruptive behavior is of course divine, and finds its ultimate validation in the passio, where the saint neatly reverses all worldly definitions of defeat and victory, rejoicing in her martyrdom while those around her suffer.

In her resistance to institutionalized power the saint is conventionally heroic: she masters obstacles and conflicts, and provokes a certain vicarious pleasure in seeing the social hierarchy tested. One would hardly conclude, however, that such narrative actually endorses either nonconformity or feminism. And the presentation of the actual moments of martyrdom should inspire similar hesitation about whether the audience "identifies" with the protagonist's apprehension of pain. 
This latter point is important. Vauchez has suggested that at the most elemental and popular level, public perception of sanctity is a kind of reflex sympathy for the spectacle of innocent suffering: "en vertu d'un processus que nous pouvons considérer comme une loi de l'affectivité populaire, la pité suscite la piété" (Vauchez 178). In a serıse hagiographic narrative must recapitulate that process in the faithful audience. As we have also seen, however, miraculous impassibility is a key element in the image of sanctity. Hence one might object that the medieval passio is scarcely pathetic at all. Knowledge of another's pain always involves an inference; so strong is our assumption of the linkage between bodily damage, pain, and the expression of distress that our empathic response at the sight of another's wounds is all but reflexive. The hagiographic representation of torture is disturbing because it tends to disrupt this inferential mechanism. It treats the saint's actual experionce of pain as unimportant. She endures, but it is often unclear what--or for that matter whether--she feels.

We should recall, however, that the true subject of a scene of pathos is often not the victim, but the witness's struggle to interpret what he sees. In the case of the virgin martyr, what the witness most often sees, and must thus come to terms with, is the victim's monumental indifference to her plight. The details of 
the physical effects of torture are often unsparing, and the saint's own relation to her dismemberment verges on the grotesque and uncanny. The transhumanized resolve of Bokenham's St, Christiana, for instance, is powerful but hardly inviting. The saint seems most profoundly alien at her moment of greatest triumph:

Whyl pese tormentours so cruelly dyde schrape Chrystynys sydis \& hir flesh dyde race, A gobet per-of, as she had lyst to iape, Sche preu, bus seying, into hir fadir face: "O ould shreu of yll dayins bat pace, Syn bou desyryst flesshe for to eet, Seke no forthere nere in noon oper place. Haue of pine own \& faste gyne to frete." (Bokenham 2467-74)

The saint's impassibility presents itself as entirely Other, a condition qualitatively different from the observer's own involuntary sense of distress. Her perfect conviction plays against the observer's own psychic fragmentation. Because the scene forecloses all possibility for straightforward fellow-feeling, the viewer must replace mere ethical reflexes with a more complex set of perceptions. The saint, like all human beings, has confronted the brute facts of oppression and physical frailty, but her eerie integrity suggests a potential reorganization of those facts. In her response to death she transfigures everyday experience, thereby revealing both spiritual and institutional truths.

Through her Cod recapitulates, in a theophanic burst, the trium- 
phal pattern of Christian history. The passio is seldom sad or tender. Yet, insofar as its protagonist effectively embodies the theology of meaningful suffering, it fulfills the literary as well as doctrinal goal of investing creatural experience with transcendent significance.

Clearly, however, the passio is not devoid of feeling. Just as the saint reverses the worldly view of victory and defeat, so, by a further interesting mechanism of reversal, the burden of suffering in the tale is often displaced from the victim onto her persecutors. In Bokenham's legend of St. Agnes, for instance, St. Peter miraculously appears to the saint and assures her that despite the pains she has suffered (including the amputation of her breasts), her tormentor has suffered more than she:

Yet hast pou hym wyth pin answere Tormentyd more ban he hath pe; For in hys conscyence ful confus ys he, And, as yt semyth, at hys wyttys ende.

(Bokenham 8649-53)

The persecutor primarily represents the pagan, secular state's hostility to the spread of Christianity. His dealings with the virgin-saint are often complicated, however, by his carnal attraction to her. His confused and self-defeating need to destroy what he simultaneously desires serves as a foil for the saint's perfectly unified will. The implication is that such worldly cupidity ultimately becomes its own punishment (for a suggestive 
discussion of this see Price 44). The following exchange between

St. Margaret and the prefect Olibrius forcefully portrays the

ricochet of suffering upon the one who sought to do harm:

Alas hure swete tendre body. so villiche todrawe so

Alas hou mi3te enyman. suche dede for rube do

Wip oules hi todrowe hure wombe. pe gottes isene were

Alas also the ssendful dede. hure deorne limes hi totere

And the Iustice for ssunness. nolde loky perto

Ac bihuld abac and hudded is ei3en . \& moni opere also

be men pat stode in pe place. and al be deol yseie

Hy made sor and deol inow . \& wope wip hore ei3e

Maide hi sede Margarete . pat so gente were \& hende

Haue reupe of pi faire bodi . pat me let pus torende

For be worp 3ute wel inou . \& pou wolle pi po3t wende

pe maide cast up hure ei3e. \& answerede atte nende

And sede $3 e$ wikked conseillers. gop fram me anon

Another conseil ich habbe itake . ich forsake $30 u$ echon

Olibrius sat and bihuld . hou hure limes ourne ablode

He nemi3te for deol it iseo. ne monie pat pere stode

Wip is mantel for reupe and deol . he helede bope is ei3e

So dude monie anoper ek . pat hi ne del neseie

Maide sede Olibrius . turne 3 ute pi po3t ich rede

And among alle wymmen bat ich iknowe . best lif pou ssalt lede

Beo stille quap pis holy maide . pou luper hond beo stille

pou hast poer of mi body . for to do pi wille

Ac mi louerd wit mi soule wel . pou nessel hure no3t aspille

For pou nemi3t hur wip al pi mi3t . anuye worb a uille

(SEL, St. Margaret, 123-46)

The tormentor here is nearly comic in his hand-wringing

distress at Margaret's fortitude. The wry effect of his confusions

about cause and effect ("Haue reupe of pi faire bodi . pat me let

pus torende") is no accident of tone, but a calculated part of the

martyr's effective witness. Likewise, those who actually carry

out the execution find themselves uncomfortably made the instru-

ments of a sort of divine joke at their expense, forced to bring 
about life through death, and brought to the absurd position of begging to be released by their own victims:

O Margarete merci . pis quellare anon sede I nedorste do for al be world . a so fol dede So muche li3t of heuene ich isee . about be in eche ende Ac ich wolde ich mi3te with pe deie . \& wip be buder wende (SEL, Margaret, 303-6)

The most important locus of emotion, however, is the crowd of witnesses always present at the public passio. Since they are not, like the prefects and torturers, the agents of persecution, their pity and terror represent a purer and more natural response to the spectacle of unjust suffering. They are, in their helpless distress, the reader's alter ego, and a reminder of the gulf between sainthood and mere human nature. Yet they also point the way to a more appropriate response than the persecutor's squeamish wish to cover his eyes. The ordeal of Bokenham's St. Faith and her associate Caprasius moves two onlookers so deeply that they

thought pey myht no bettyr do Than to be ioyned to bem tweyne; And euyn furth-wyth pei runne hym to And alle her hert opynly dede seyne, And anon bei applyid were to peyne; And bus pese four, togedyr knyt sothly, Of furyous dacyan had be victory.

(Bokenham 3958-64)

Those who witness properly will grasp the real meaning of martyrdom, responding not with mere reflex emotion, but with moral 
and spiritual resolve to be joined with the saints.

The transformation of suffering in the passio thus becomes a literal reflection of the essential paradoxes of Christianity. As Elaine Scarry argues in The Body In Pain, political torture attempts to substitute one power--the capacity to inflict pain--for the less easily achieved power to control the prisoner's thought and speech. In surrendering to the overmastering dictates of pain--of the body's own attempt to resist dissolution--the prisoner is falsely regarded as having surrendered to his persecutor's ideological demands. Scarry notes that the Christian scenario of martyrdom vividly manifests this symbolic substitution of the prisoner's body for his mind; but it also, through the saint's ability to transcend this substitution, reveals the essential illegitimacy of the entire enterprise: "it is not that the concept of power is eliminated, and it is certainly not that the idea of suffering is eliminated; it is that the earlier relation between them is eliminated. They are no longer manifestations of each other: one person's pain is not the sign of another's power" (Scarry 214).

The narrator and his audience, inhabitants of the less heroic and charismatic latter days of Christianity, are presumably unable to achieve the saint's perfect courage and detachment; nevertheless, in urging his readers to consider the grisly details of the passio in terms of its ultimate significance rather than its mere 
experiential circumstances, the hagiographer invokes an eternal perspective, a kind of "supra-realism" which allows the audience to glimpse a world re-ordered according to divine truth rather than mere human and material appearance. For instance, the narrative of St. Agnes' dismemberment becomes not a lurid fantasy, but an almost heraldically-conceived emblem of the church militant:

He let nyme a kene swerd . \& poru hure prote smite be rede blod orn adoun. ope hure limes so wite bat fairer bing nemi3te beo . banne was bat swete blod Upe hure limes bat were so wite (SEL, Agnes, 123-6)

What P.M. Kean says of the Second Nun's Tale is true of the saint's legend in general: "the purpose of the narrative is not to provoke any of the reactions which could be associated with the contemplation of actual suffering. The point is to present one more great witness to divine truth" (Kean II, 204). Just as the classic passio transforms defeat into victory, pity into resolve, and horror into beauty, so it offers less an example of how to suffer than a blazing icon of God's power.

The simplicity--that is, the singleness and unity--of this message is a prominent feature of medieval hagiography, and Chaucer's Second Nun's Tale is no exception. Indeed, its current readers are sometimes disappointed at the tale's sheer lucidity, its apparent lack of the ambiguities and complications for which 
Chaucerian narrative is now prized. It adheres closely to its known Latin sources (the Legenda Aurea and the eighth-century Passio S. Caeciliae; see Reames, "Sources" for a discussion of how Chaucer combined the two), it offers no dramatic tension between tale and teller, it reveals no ambivalence about its protagonist or themes. Clearly, in ways that can be very briefly summarized, the Second Nun's Tale is a traditional saint's legend. First, the sorts of authorial purposes we noted above are explicitly invoked in the prologue. The narrator offers her tale "for to putte us fro swich ydelness" (G 22), a vice which she has described in the preceding stanza as "oonly to slepe, and for to ete and drynke, / And to devouren al that othere swynke" (G 20-21). The emphasis is decidedly on the extra-aesthetic value of the story as a devotional exercise for both audience and author: "And, for that feith is deed withouten werkis, / So for to werken yif me wit and space, / That I be quit fro thennes that most derk is!" (G 64-6). Mary Giffin has proposed that Chaucer's translation of the Cecilia legend commemorates the appointment of Adam Easton, an English cleric originally attached to Norwich Cathedral Priory, as Cardinal Priest of St. Cecilia's church in Trastevere; if this is so, it makes even clearer the tale's connection with extra-literary cult activities (Giffin 31). In short, Chaucer's aim in the Second Nun's Tale is a kind of spiritual fruitfulness more commonly associated with 
worship and preaching than with story-telling.

Equally conventional is the tale's emphasis on the ironic paradox at the heart of the martyr's victory. Cecilia is shown as a particularly self-aware non-conformist, as when she prefaces her pillow lecture to Valerian with wifely mock-deference: "O sweete and wel biloved spouse deere, / Ther is a conseil, and ye wolde it heere, / which that right fayn I wolde unto yow seye" (G 144-6). Pope Urban relishes the reversal as well: "For thilke spouse that she took but now / Ful lyk a fiers leoun, she sendeth heere, / As meke as evere was any lomb" (G 197-9). Most fully developed in Chaucer's legend, however, is the satisfying frustration of worldly power at the hands of God's lowly servant, a conclusion made concrete in the metaphor with which Cecilia contemptuously dismisses Almachius and his threats:

"Youre myght," quod she, "ful litel is to dreede,

For every mortal mannes power nys

But lyk a bladdre ful of wynd, ywys.

For with a nedles poynt, whan it is blowe,

May al the boost of it be leyd ful lowe." (G 437-41)

As all students of hagiography are bound to notice, however, the Second Nun's Tale is distinctively austere in its presentation of the saint's inward being, whether this is conceived in terms of suffering, or more simply in terms of ordinary human emotion. In part this effect is the result of the tale's focus on Cecilia's mis- 
sionary work: the climax of the legend is accordingly shifted from her death to her trial, and the details of her martyrdom, though never under-emphasizing the miracle whereby she continues to preach with her throat cut, are treated as little more than an impediment to her continued work as a teacher and agent of conversion. As V.A. Kolve has shown in his analysis of the iconography of St. Cecilia, Chaucer seems specifically to suppress the sensational and erotic possibilities of the saint in her "bath of flambes rede"--possibilities meticulously exploited in the many pictorial representations of Cecilia's pearly nakedness, her face and hands raised to heaven in a gesture of piteous supplication (Kolve, "Second Nun's Tale," 143-50). Kolve rightly suggests that her coolness in the suffocating bath "represents a condition beyond the reach of carnal heat or physical fire" (Kolve, "Second Nun's Tale" 153-4). It is also, however, part of the tale's emphasis on Cecilia's sacredness as a kind of alterity. The tale refuses to treat her as a personality accessible to our inspection. The sole reference to any inward state of hers occurs at her wedding, and its terms are wholly conventional: she secretly wears a hair shirt, and prays "to God allone in herte" for the preservation of her virginity (G 133-37). As the forensic quality of her encounter with Almachius shows, the nature of her suffering is less important than her deeds: in the fullest possible sense, this 
saint is what she does, and whatever may be important about her finds complete expression in the "manye wondres Jhesus for hem wroghte" (G 359).

Sherry Reames ("Cecilia Legend") has argued that this presentation of Cecilia as a monumental, wonder-working figure is part of the same deviation from the hagiographer's proper task that she finds in the Legenda Aurea. In particular she objects to the way that both Jacobus and Chaucer excise much of the doctrinal material which Cecilia expounds to her prospective converts in the longer and more detailed Passio S. Caeciliae. The consequence, she argues, is a narrative which fails to reflect the difficult spiritual realities of early Christian conversion, and which reduces doctrine to "oversimplifications and easy assurances" (Reames, "Cecilia Legend" 50). She particularly objects to the tale's depiction of conversion as "a phenomenon altogether separate from the ordinary, intelligible processes of human deliberation and consent," and as a sort of miracle wrought by "a higher power than Cecilia" (Reames, "Cecilia Legend" 51). I have already suggested that Reames' preference for an exemplary rather than iconic model of sanctity expresses a common misconception; her argument that the tale distorts human experience seems to me equally instructive in its reliance on modern assumptions about the author's and audience's expectations concerning 
such narrative.

Her analysis is quite exhaustive, but a single small example can make clear her general approach to the text. She interprets the episode in which Cecilia and Valerian convert Tiburtius thus: "their quick, sketchy explanations suggest that the important thing is to get him baptized, whether or not he understands what this step means" ("Cecilia Legend" 48). Her claim that the legend depicts a questionable standard of behavior rests on a psychological model for conversion and knowledge of God which she draws from St. Augustine, and which she finds utterly lacking in Jacobus and Chaucer's legends; she also relies, though less explicitly, on the supposition that both Chaucer and Jacobus must have known--and been impressed by--the risks and difficulties associated in early Christian times with the decision to accept baptism. The tale fails, then, to do justice to certain intellectual and historical realities which it ought, in Reames' view, to mirror.

Reames' reliance on an Augustinian description for psychological orthodoxy is of course open to the usual charges against so-called "patristic" readings of Chaucer: is it reasonable to expect that a mere tale should shoulder the burden of an analytic clarity more properly borne by other forms of discourse? Even sermons characteristically alternate exemplum with exposition, as if to acknowledge the essential difference between the two. One 
might also ask whether a legend designed for an audience of believers (and indeed, in the case of Jacobus, an audience of professional expositors of doctrine) needs to contain the instruction whose excision Reames laments. Indeed, it seems equally reasonable to propose that what the tale leaves out is what its audience least needed to hear.

More difficult is Reames' claim that because the narrative offers us none of Chaucer's "customary methods" ("Cecilia Legend" 54) for signalling irony, it must constitute disturbing evidence of Chaucer's own "spiritual values and priorities, his preconceptions, his own mental picture of the Christian life" ("Cecilia Legend" 56). We can scarcely do literary criticism without accepting at least some version of this notion; and a regular source of interpretive controversy is our inability to know how completely or reliably any literary work conveys its author's ideas. Behind all controversies about authorial opinion, however, lies the assumption that narrative gives the poet an opportunity to tailor his materials according to his own fancy and vision. Since fiction (even historical fiction) is essentially confected, the author is responsible for shaping and defining its meaning. As I suggested in the preceding chapter, this is a view of narrative as exemplary. It is also, of course, an idea in accord with the modern view of sainthood as imitable and ethical- 
ly normative. The hagiographer's task is to carve out his personal vision of what the particular facts of a particular saint's life mean.

But as I also suggested in the preceding chapter, medieval culture admits of an alternate mode of narrative, of which hagiography is a prime instance. If, as I have claimed, the second. Nun's Tale is a deliberately traditional piece, we will find little warrant for treating it as an expression of Chaucer's "own mental picture of the Christian life." We need not imagine that he writes in despite of his own views, but for the author of an iconic narrative those views are secondary. In a very real sense the story itself has its own "spiritual values and priorities," its own "mental picture of the Christian life." These, rather than inferences about Chaucer's private mentality, should be the object of the critic's scrutiny, since these give us the opportunity to examine how the audience is invited to interact with the legend, and to make certain speculations about the essential status of the text.

As we have seen, the task of emotional expression within the hagiographic narrative is often displaced onto secondary characters whose responses anticipate or mirror the possible responses of the reading audience. It is perhaps too much to say that such emotion is narratively discredited or rejected, but often it is 
shown to be limited and even self-defeating, an imaginative failure to convert the mere appearance of martyrdom into its spiritual reality. Reames is right, therefore, to fix on literal conversion as a key theme in the Second Nun's Tale, for even as Chaucer's restrained presentation of suffering emphasizes Cecilia's uncompromising contemptus mundi, it also makes room for a precise and delicate treatment of distinctively human emotion through the experiences of those surrounding the saint.

There is actually a good deal of affective response in the Second Nun's Tale, including fear, astonishment, joy, and the more usual grief, as when the officer Maximus "hymself weep for pitee that he hadde" (G 371) at the prospect of carrying out the martyrdom of Valerian and Tiburtius. Interestingly, however, his grief leads to his own conversion, and to that of others:

This Maximus, that saugh this thyng bityde, With pitous teeris tolde it anonright, That he hir soules saugh to hevene glyde With aungels ful of cleernesse and of light, And with his word converted many a wight. (G 400-404)

The implication seems to be that such tears, though based in simple pity, are potentially like the tears of true contrition which lead from sorrow to new resolve:

But they, converted at hir wise loore, Wepten ful soore, and yaven ful credence Unto hire word, and cryden moore and moore, "Crist, Goddes Sone, withouten difference, Is verray God--this is al oure sentence-- 
That hath so good a servant hym to serve.

This with o voys we trowen, thogh we sterve!"

(G 414-20)

Thus the pity of the onlooker, its reflexes rooted in empathy for the victim and recoil from her imagined pain, is regularly transformed within the tale from a sign of human limitation to a sign of spiritual progress.

One explanation for the emphasis on this particular emotion certainly lies in the tale's essentially functional rather than representational status. For Augustine and the earlier Christians conversion may indeed have been above all a matter of doctrinal acceptance. But as Charles Singleton notes, for later-medieval Christian Europe conversion signified not the dogmatic acceptance or entry into Church membership which everyone took for granted, but rather the re-dedication of the will to a new, more focused and intense devotion (Singleton 39). This is the sort of conversion, I think, that preoccupies Chaucer in the Second Nun's. Tale, a conversion fitly symbolized in tears and in the tale's imagery of gradual change. Tiburtius' first intimation of eternal life is neither an intellectual conviction nor a spectacular illumination, but the apprehension of inward metamorphosis: "The sweete smel that in myn herte I fynde / Hathe chaunged me al in another kynde" (G 251-2). This sense of a liminal moment when the soul glances backwards even as it reorients itself is suggest- 
ed by Tiburtius' wonderment and by Valerian's description of his new life as a Christian:

Tiburce answerde, "Seistow this to me In soothness, or in dreem I herkne this?"

"In dremes," quod Valerian, "han we be

Unto this tyme, brother myn, ywis.

But now at erst in trouthe our dwellynge is."

(G 260-64)

We have seen that it is not entirely satisfactory to regard the saint herself as the exemplary object of imitation or of literary identification. Clearly such is the case with Chaucer's St. Cecilia. If anyone in the tale serves an exemplary function, it ought to be Valerian, Tiburtius, and the tale's other converts. The tale's interest in the nuanced stages of conversion, particularly as these contrast with Cecilia's numinous absoluteness, offers a more than usually particularized vision of how an encounter with sanctity can affect belief. It also, as Reames shows, excludes or downplays the intellectual underpinnings of Christianity. But the tale's relative disregard for the historicallyconditioned anxieties and doubts of catechumens facing persecution is not, I think, an indication of decadent or narrow religiosity. Indeed, just as it is doubtful that the tale offers a fictive recreation of early Christian history, so I am not entirely sure it attempts any encompassing image of Christian faith and practice. Instead it restricts its psychological focus to a single set of concerns and attitudes--namely the dispositions underlying the 
veneration of saints. If it can make sense to say that a text identifies with its readers rather than vice-versa, the second Nun's Tale would surely be a prime instance. For what it represents to us is not the world as seen by early Christians, or the individual Christian's struggle to embrace the doctrines of his faith, but the cult of St. Cecilia and the dispositions of her devots. The legend teaches not how to be saintly, or how to suffer, but how to pray.

Thus the tale's image of the appropriate response to sanctity, like its refusal to present Cecilia in characterological terms, is part of a remarkably streamlined functionalism. The narrative, like the saint and her converts, serves a purpose beyond itself. The weirdly expressive comparison which concludes the etymology section of the prologue makes very clear the process of divine signification whereby God exercises his unique prerogative to make persons into signs:

And right so as thise philosophres write That hevne is swift and round and eek brennynge, Right so was faire Cecilie the white Ful swift and bisy evere in good werkynge, And round and hool in good perseverynge, And brennynge evere in charite ful bright.

(G 113-18)

This description all but effaces the saint's human image, working its own kind of dismemberment in the interests of ideology. The reference to Cecilia as "the white" only emphasizes, with its echo 
of conventional terms of praise for female beauty, the narrator's determination to construe Cecilia in another way. The literary form of this image is determined by its doctrinal function. Like the other representational devices associated with hagiography--the polarization of good and evil, the tendency to neglect the description of the inner life, and to simplify its psychological model as far as possible--it points to the legend's goal of glorifying the transcendent triumph of God and the Church, not of instructing the faithful in how to bear the trials of this world.

The degree to which the Second Nun's Tale allies itself with the world outside the text is worth emphasizing. It implies that art may have unmediated moral impact: the devotion one feels in hearing the life of a saint is no different from the devotion one feels in the exercise of other religious activities. In Chapter One I suggested that texts of this sort, insofar as they are part of the apparatus of worship, should be called iconic. In the case of the Second Nun's Tale the term is quite literally apt. The sort of substitutions which the etymologies exploit, whereby the familiar outline of a woman is replaced by a rapid series of visually disparate but spiritually identical images, suggests other familiar Christian substitutions of thing for person: the holy image, the relic, and the eucharistic wafer. The perfect ease and apparent literalness with which the narrator offers these comparisons 
suggests their sacramental character. Far from being pious fiction, artful conceits, mere figures of rhetoric, the etymologies represent the legend's capacity to transfigure language into the holy.

In such sacred objects such as the eucharist, the relic, or the icon, the material elements of bread, paint, desiccated bone, and so forth, are transformed by a mysterious participation in the divinity they represent. Because an icon seems so clearly to be an artifact, it occupies a special sacramental category to which hagiography may also be assigned. Some icons are, like the veronica, miraculous objects produced entirely without human agency. Others, like portrait of the Virgin preserved at Santa Maria Maggiore in Rome and attributed to Saint Luke himself, are "documentary" images made while their subject was still living. Their special nature, however, lies in their reproducibility. Like saints' legends, icons may be copied, are indeed themselves copies which may vary slightly in detail from their exemplars. Eastern Orthodox doctrine, however, reasons that their accuracy and holy efficacy is never in doubt, for the icon-painter records not his own fancies, but

factual knowledge, something seen if not by himself, by a trustworthy witness. The experience of this witness, who received and transmitted the revelation, is increased by the addition of the experience of all those who have received it after him. In this way 
the singleness of the revealed truth is joined with the multiform personal experience of those receiving it. In order to receive and pass on the testimony, the iconographer must not only believe that it is genuine, but must also share in the life, by which the witness of the revelation lived, must follow the same way, that is, be a member of the body of the Church. (Ouspensky and Lossky 42)

The artist's self-effacing fidelity to tradition helps to insure that he has preserved the essential features of his subject, while his devotion to his all-important work helps to preserve and transmit its divine and miraculous origins.

Hans Belting argues, in The Image and Its Public in the Middle Ages, that the proliferation of devotional images in the thirteenth and fourteenth centuries is directly related to the importation of actual Byzantine icons. The lore associated with these mysterious images was congenial to a religious culture already inclined towards vivid affective piety and fervent curiosity about the central events of Christian history. Whatever the official prohibitions against idolatry, in practice sacred images become the devotional equivalents of the now-distant persons or events they represent: "The image is no longer restricted to the function of a silent symbol which merely means or takes the place of reality. Instead it became capable of portraying reality as the beholder knew it and, by showing it, of proving the very existence of such reality" (Belting 220).

My earlier analogy between hagiography and the visual arts 
may indeed be more than just an "as it were." Heffernan cites two very interesting cases in which "sacred biographers" ally their own work with portraiture. The first is Agnellus of Ravenna, whose eighth-century Liber Pontificalis Ravennatensis relates the lives of all forty-five bishops of Ravenna. In his preface he discusses the difficulty of obtaining documentary information concerning some of his subjects, and discusses the strategies he has employed when written evidence was lacking:

But concerning their appearance, if by chance there will be a discussion among you, as to how I was able to know: you must understand that portraiture taught me, because always images were made in their times after their likeness. And if an argument shall arise from the portraits to the effect that I should have confirmed their appearances: the holy bishop Ambrose of Milan in the Passion of the Blessed Martyrs Gervase and Protase with regard to the appearance of blessed Paul the Apostle stated these words: "A portrait taught me his face." (Heffernan 162)

The second example is Reginald of Canterbury's Vita Sancti Malchi (completed 1107), a learned and elaborate hexameter composition, intended for a monastic audience, in which the author promises to deliver a representation of the long-dead saint by which the reader "may contemplate him not as in a glass, but as if face to face" (lector non quasi in speculo sed tamquam facie ad faciem intueri poterit; Heffernan 134). Heffernan, who rather fitfully adheres to the exemplary model of sainthood, finds both these examples perplexing. And indeed, if we think of hagiography and 
biography as purely linguistic and textual modes--as fundamentally made of words--these references to visual contact with the subject are disconcerting. But if we think of hagiography as fundamentally congruent with iconography, we see how the contemplation of images, whether literal or in the mind's eye, becomes an intelligible means of transmitting sacred traditions.

The role of language in this transmission is summed up in the medieval notion of translation. From a purely literary standpoint, of course, translation is no more than a matter of words --of discovering regular correspondences between two symbol systems. Yet it seems clear that a very different conception of the translator's task motivates the following remarks from the prologue to the anonymous legend of Fortunata:

The passions of the holy martyrs are held to be of less authority because in some of them falsehood is found mixed up with truth. . . . My method has been to set down the Passion of the holy martyr Fortunata in my own words, cutting away what was superfluous, adding anything necessary, amending what was corrupt, correcting what was extravagant and rearranging what was disorderly. (Prologus ad Passionem S. Fortunata v. et m., in Mai, Spicilegium Romanum IV, cited in Delehaye 67)

Delehaye cites this passage as proof that "the simple minds of these semi-barbarous scribes were lacking in the very first qualification for exercising the critical faculty in however slight a degree" (Delehaye 66). And indeed, it is tempting to smile at the 
Fortunata-author's naivete just as we do at the narrator's claim, in Troilus, Book I, to give "naught only the sentence" of Troilus' lament, but also what his "auctor called Lollius" has omitted: "Loo! every word right thus / As I shal seyn" (T\&C I, 393-7). Yet remarks like these can also suggest a more complex attitude toward the editor's and translator's task. The hagiographer approaches his subject like a restorer of a painting: the "superfluous," "corrupt," and "disorderly" elements in his sources are like encrustations of soot and clumsy retouching which can be removed to reveal the outlines, colors, and textures of the original image. Instead of viewing his sources as independent competing witnesses, the Fortunata-author treats them as if they were successively-added layers upon a single surface (the table of collective memory, perhaps), some of which enhance the original lineaments, and some of which obscure them. His own version will be not a redaction, but a restoration. In a hagiographical context, therefore, to deny artifice is no modesty topos, but an expression of faith in the divinely instituted legendary tradition, and in its power to render language a perfect instrument of divine revelation--just as the saint herself was such an instrument.

The narrator of the Second Nun's Tale draws attention to this aspect of her narrative when she protests that "I do no 
diligence / This ilke storie subtilly to endite" (G 79-80). The word "subtile" carries a range of meanings from the laudatory "refined" and "ingenious" to the much less approving "sly," "underhanded." Always, however, it connotes a kind of selfconscious artifice. In denying "subtilte" the narrator claims that the legend--like the relic, the icon, and the eucharist--transcends the limits of its perishable materiality. When she asserts that "I have heer doon my feithful bisynesse / After the legende, in translacioun / Right of thy glorious lif and passioun" (G 24-26) she means something quite different from the mere conversion of Latin prose into English rhyme royal. What she has "carried across" is not just the legenda--the mere traditional words about the saint--but essence of the "glorious lif and passioun" itself. Such a notion of words as fully serviceable underlies the medieval theory of sermo humilis, and a faith in words as the transparent medium of revealed historical meaning--translation in its fullest sense--is central to the hagiographic conception of narrative. As Peter Dembowski puts it,

le récit hagiographique tend lui-même à devenir un "objet," une phrase commémorative, souvent apprise par coeur. Si le sort ultime d'un exemplum est de devenir proverbe--c'est en ceci qu'est la preuve finale de son "succès"--le sort ultime du récit hagiographique, le signe de son véritable "succès," c'est de devenir un emblème verbal dont la véracité est garantie par la connaissance préalable de la légende, par les objets de culte, bref, par ce culte lui-même. (Dembowski 87) 
This notion of hagiographic narrative offers a considerable departure from the generally ornamental conception of language which dominates medieval secular rhetoric, and which Chaucer himself expresses elsewhere in his work, most notably at the end of Troilus and Criseyde. At its most extreme it implies that saints' legends are not "literary" at all, in the sense that they are not fictive, not primarily made of language. The words of the legend, like the relics and the liturgy surrounding the cult, do not so much constitute a constructed or imagined reality as they provide an iconic, sacramental point of contact with a historical moment of theophany which would otherwise be no more than a memory

This discussion has emphasized the ways in which hagiographic narrative differs from secular story-telling, and even at times works to defeat the expectations of readers accustomed to other sorts of texts. Yet the modern confusions surrounding the nature of hagiography would scarcely arise if it were not also true that the saint's legend shares much with secular narrative. Indeed, the author of the South English Legendary offers his collection as an edifying substitute for less fruitful kinds of entertainment:

Men wilnep muche to hure telle . of bataille of kynge And of kni3tes bat hardy were . pat muchel is lesynge Wo so wilneb muche to hure. tales of such pinge Hardi batailles he may hure . here pat nis no lesinge Of apostles \& martirs . pat hardy kni3tes were 
pat studeuast were in bataille . \& ne fleide no3t for fere pat soffrede pat luper men. al quik hure lymes totere (SEL, Prol. 61-5)

As the author of these lines knows well, hagiography and secular narrative are in competition precisely because both offer the sheer appeal of narrative itself, of experience invested with moral and formal coherence: people simply "wilneb muche to hure telle." Particularly in its treatment of suffering, hagiography seems highly conscious of its power to stir the reader. Yet the central intellectual image of the passio--the metamorphosis of victimization into conquest--demonstrates the structured and determinate nature of its expected audience response. To respond to the legend any other way is to have misconstrued it. In short, because the legend enacts not just any sequence of psychologically charged events, but the actual mythos of the cult, the reader' experience of narrative pathos is itself transformed into a devotional act with real spiritual and moral validity. But it does so, I will argue, by virtue of its alliance with a certain clearly-defined form and ideology. The question to be addressed in the next chapter is whether the erosion or exclusion of such doctrinal intentions must also damage the delicate emotional equilibrium and moral lucidity characteristic of the saint's legend. 


\section{CHAPTER THREE}

THE "PALE FACE" AND THE "FAIRE RODE":

DEVOTIONAL STYLE IN THE MAN OF LAW'S TALE

The Second Nun's, Man of Law's, and Prioress's Tales are often described as forming, together with the Physician's and Clerk's Tales, a sort of "pathos group" within the Chaucer canon. Four of these five tales are of course linked by their rhyme royal stanza-form, while as a whole the group seems to draw on a common stock of plot motifs. As Saul Nathaniel Brody puts it, these tales share

not only the rhyme scheme, but also the slit throats that fail to silence the victims in the Second Nun's and Prioress's Tales, the wedding night scenes in the Second Nun's and Man of Law's Tales, the suffering mothers in the Prioress's, Clerk's, and Man of Law's. Tales, the wedding garments in the Second Nun's and Clerk's Tales--in short, a series of interlaced stylistic features, images, personalities, and events that draw the tales together. (Brody 128-9).

These tales have also often been perceived as linked by their rhetorical orientation. Thomas H. Bestul has noted that they "depend for their effectiveness upon the arousal of a distinct emotional response in the reader" (Bestul 216). That is, they attempt to arouse the reader's pity for their suffering protago- 
nists, and they accompany that attempt with a certain degree of rhetorical heightening and ornament. Robert O. Payne, in commenting on this affective quality, has called the pathos group Chaucer's "sentimental experiment" (Payne 164). They are not, however, especially congenial to modern sensibilities. As Donald Howard tactfully puts it, "they represent a stylized kind of art which is no longer palatable and an idealism long since out of vogue" (Howard 290). Morton Bloomfield is more forthright in voicing the common perception: "Not only are the pathetic tales hard to enjoy but their rationale escapes us" (Bloomfield 384). "They are," he declares, "the embarrassment of the Canterbury Tales" (Bloomfield 384).

The tales of the "pathos-group" are often perceived as vaguely "hagiographic" (Payne 157; Paull; Strohm; Dunn), and readers often cite the decorum of the traditional saint's legend as an explanation for their style and structure. The key feature of interest seems to be, as one might expect, hagiography's disregard for verisimilitude and psychological realism. For Bernard I. Duffey, for instance, in the Man of Law's Tale

the idea of character changing through the events of narrative, or of revealing itself by the same means, seems to have been quite absent from Chaucer's mind when he worked out this tale. Custance here exists not as an interesting person in herself, nor as a study in character development. She exists, like so many other devices of the story, as a means toward certain definite ends of emotional impression. (Duffey 
186)

Edward A. Block argues, on the contrary, that Chaucer bravely attempts to add "vivid details and humanizing touches" (592) to his adaptation of Trivet's portrayal of Constance, but that "to expect of Chaucer that he should have written a credible saint's legend is, after all, to expect the impossible--even of him" (616). Even Bloomfield, who believes himself to be offering an apologia for the tale's world-view and aesthetic, nonetheless categorically asserts that "we cannot identify ourselves emotionally with a protagonist we perpetually feel superior to and whose sufferings create no awe in us" (Bloomfield 385).

This "hagiographic" theory of the Man of Law's and Prioress's Tales deserves considerably deeper consideration than it has received. In some ways it is a useful comparison, for it calls our attention to the special character of these tales' subject matter. But as the comments I've just cited make clear, all too often the theory is based on some fairly serious misunderstandings of hagiography itself. As my analysis of the Second Nun's Tale has shown, hagiography is not particularly marked by some of the features most prominent in the Man of Law's and Prioress's Tales. In particular, they differ from the Second Nun's Tale in what might be called their self-consciousness--their awareness of their own status as narrative. One indication of this is their 
more clearly personalized narrative voices. Another is the reader's pervasive sense that the tellers of these tales are well aware that they're creating an "effect": what makes the tales work is not simply the force of legend, but the artfulness of the teller's dispositio. One might also note that neither tale is, in any case, a saint's legend. The Man of Law's Tale is a chronicle history, while the Prioress's Tale is a miracle of the Virgin. While both genres share with hagiography a broadly religious concern for the irruption of the sacred into everyday life, they do not present us with thaumaturgic protagonists. Wonders attend Constance and the little clergeon, but neither character is actually transformed into the saint's living embodiment of miraculously sanctified suffering. And since neither protagonist is a saint, neither tale clearly directs itself towards reinforcing the public, cultic life of the Church. Instead the Man of Law's and Prioress's Tales employ the image of innocent victimization, as the legends characteristically do not, to address private, ethical matters of faith. To "explain" these tales by reference to the presumed extravagance and illogic of their presumed hagiographic ancestors is to overlook what is most distinctive and interesting about them. In this chapter and the next I will insist that these differences matter. They indicate the ways that these tales depart significantly from the hagiographic model: in both their 
genres and individual styles they move away from iconic narrative towards the exemplary.

One of the few features of the Man of Law's Tale about which all readers agree is its strongly rhetorical bent. The significance of that high style, however, is certainly the subject of widespread dispute, a confusion made all the more acute by the modern reader's lack of sympathy for rhetorical artifice and stylization itself. Some readers do defend the Man of Law's reaching after sublimity (Bestul; Benson; Lawton), but on the whole twentieth-century scholars have found it difficult to accept the tale's rhetorical stance straightforwardly. In particular, many Chaucerians intuitively agree with Morton Bloomfield's remark that "looking over this whole extremely elaborate rhetorical machinery we have been discussing, we become aware of how it stands between us and the tale, distancing us from and stylizing the action, and refusing to allow us to identify with the suffering heroine" (Bloomfield 386; similarly Johnson 206). Michael R. Paull defends this characteristic as appropriate to a hagiographical tale, but evidently cannot justify it on any other grounds: "There is no attempt to get the reader to empathize with the dramatic action of the Tale. In fact, by continually breaking the dramatic illusion and pointing out the ultra goodness or badness of the characters, it would seem that the Tale actively discour- 
ages and, in some cases, even mocks its ability to do this" (Paull 193). Commentary on the narrator of the Man of Law's Tale seems to echo T.S. Eliot's remarks on Hamlet's grief: the intensity of the teller's response is in excess of the facts as they appear. Judgments like these seem to arise from an unwillingness to trust the narrator's voice, a voice which continually urges us to take a certain attitude: a passage beginning "O my Custance!" must, at least on some level, be meant to induce in its readers the same feeling of agitated tenderness which it expresses. The terms in which these exhortations appear, however, are not inviting; indeed, they seem to produce a response quite opposed to their intended one. One way to relieve our sense that the narrator is breathing heavily down our necks as we read is, as so often in Chaucer studies, to divorce the teller from the author. If we take it as self-evident that Chaucer shared our view of rhetorical display as automatically alienating, we can account for our uneasiness. Style no longer inhabits the tale as narrative vehicle, but rather as an unconscious revelation of the teller's pomposity, worldliness, and so on. The potential for circularity in this kind of argument is apparent in Rodney Delasanta's remarkable assertion that "rhetorical declamation is simply not normal Chaucerian strategy unless it is mischievously directed against its practitioners, especially when we find it floating free 
of its dramatic anchor. One has the distinct impression that Chaucer removes rhetorical display from those narrators who are simpatici while reserving it for those narrators who are not" (Delasanta 298-9). The conjunction of high style with a suffering protagonist in the Man of Law's Tale thus raises genuinely central concerns not just about modern attitudes towards ornate language, but also about how such rhetoric functions within religious narrative.

In what follows I mean to set aside, at least temporarily, the question of how the tale may or may not betray the biases of the worldly lawyer described in the General Prologue. My contention will be that we cannot evaluate style as an aspect of the teller's personality until we have some sense of what that style is, of what it does, and of whether it might exist independent of the personae of the Canterbury-drama. The following discussion is therefore an attempt to supply a fuller context in which to set the tale's spiritual vision, its relation to its audience, and its status as text. I will begin with some observations, based on a comparison between certain key passages in Chaucer and Trivet, about how style operates in the tale. I will then try to establish that the ornate language and intensely stylized representational techniques of the Man of Law's Tale are not, in historical terms, particularly idiosyncratic. Rather they are quite distinctly 
borrowed from certain kinds of late medieval devotional literature. I will argue that just as hagiographic narrative furnishes a helpful standard for appreciating the sermo humilis of the second Nun's Tale, so the vernacular religious lyrics and gospel meditations of the fourteenth century can do much to enlarge our understanding of the Man of Law's Tale's self-consciously "subtil" and ornamental style. I will end with some speculations (necessarily tentative) about how my findings should modify our appraisal of narrative persona in the tale. Throughout my analysis I will avoid reference to the "Man of Law"; my use of the terms "Chaucer" and "the narrator" is intended neutrally, simply as a convenient designation for the teller's voice.

The Chroniques are, like the legends of the saints, historical documents. A commonplace of Man of Law's Tale criticism has been the notion that Chaucer attempts various improvements upon Trivet's uninspired account. His having done so may, in light of the previous chapter's analysis of hagiography as the translatio of iconic history, seem to compromise my thesis about the devotional author's fidelity to the sacred status of his sources. The truth-claim of the Chronigues is not, however, quite that of hagiography. Kolve emphasizes Trivet's employment of "real personages inhabiting a real past," who "confer upon the whole narrative an important kind of medieval credibility; moral meaning 
emerges from a historical narrative" (Kolve, $\underline{C}$ and the Imagery, 299). This remark rightly sums up, I think, the effect both of Trivet's Chroniques and of the Man of Law's Tale; Kolve's key terms, however, also suggest the ways that the status of chronicle history differs from that of scriptural and sacred history. First, the establishment of "moral meaning" is, as we have seen, secondary to the hagiographer's goal of educating his readership and encouraging their participation in the cult of saints. Second, the notion of a significance that "emerges" from events, with its connotations of submergence and latency, is altogether foreign to hagiography. The author of a saint's legend strives to reproduce, as purely as possible, the electric quality of an event whose meaning was instantly clear and manifest to all witnesses. The historian, on the other hand, undertakes to discern, in the sheer great shifting accretions of human events, the governing patterns of divine and human action, and to render those patterns visible. These differing tasks require qualitatively different literary methods and authorial stances. Where the hagiographer need only display his iconic subject, the historian must demonstrate his subject's exemplary value. The historian operates in the realm of the conditional and probative; the persuasive requirements of his enterprise are thus fundamentally literary, and his success depends on the skill with which he constructs a 
text from which meaning may then emerge.

The tale's best-known source critic, Edward A. Block, contends that Chaucer's re-construction of Trivet consists of an effort to introduce vivid detail, excitement, and sharper characterization into an otherwise drab and summary narrative. These qualities, Block implies, are good in themselves, and bear witness to Chaucer's superior aesthetic sense. My own examination of the source, however, does not quite bear out this conclusion.

Trivet's Chroniques are anything but drab, and Chaucer's adaptation is anything but a simple enlivenment. Style in the Man of Law's Tale is more than just ornament. It is, in fact, inseparable from the historian's demonstrative task, and Chaucer's rather different selectivity and narrative focus reveals how the meaning of his tale diverges form Trivet's. A particularly clear instance is Constance's trial scene, which occurs at the very center of the tale, and which brings together, in microcosm, virtually all of the rhetorical and narrative strategies of the text as a whole.

Trivet's version of the episode supplies a standard against which to appraise Chaucer's strategic reshaping:

A ceo apres poy de de tenps entra Elda le chastel, e en haste vint a la chaumbre sa compaine pur counter nouele de la venue le rey. Constaunce, qe oue la noyse estoit aueile, quidaunte la dame dormaunte, lui moueyt la mayn pur la veiler. E quant ele senti que le corps lui estoit tut moil de saunc, a grant affray dist encriaunt: "Ma dame est morte!" A quele parole Elda e qui estoient en present, trop abais de la 
parole, come ceus que riens nentendirent de la felonei, accriauns "Lumere! Lumere!" trouerent la goule Hermengild hidousement trenche e le corps tut envolupe en saunc. E quant tous acrierent la crueute, en demaundaunt de Constaunce la verite, cist tretres, qi auoyt fet la felonie, hugement surmist la mort sur la pucele, e par countenaunce que la mort lui estoit plus pres a quoer qe as autres, saili a toute pars com homme arage, taunqe il eust troue le coteil la ou il lauoit mesmes musce; e deuant touz moustraunt le instrument de la felonie, a huge crie apela la pucele de tresoun. Mes Elda, qi ne poeit cele crueute penser de la pucele, bonement la defendi. E cil maueys en haste prist entre mains le liure leuesqe Lucius, auant nome, questoit liure dez Ewangeiles, qe lez seintes femmes, Hermyngild e Constaunce, chescune nuyt par deuocioun auyoent encoste eles; e sur cel liure iura en criaunt, si dieu lui eydast e le Ewangeile e son baptesme, que ia nouelement auoit resceu, qe Custance fu la felonesse, mordrere la dame. A peine auoit parfini la parole, qe vne mayn close com poyn de homme apparut deuant Elda e quant questoient en presence, e ferri tiel coup en le haterel le feloun, qe ambedeus lez eus luy enuolerent de la teste, e lez deentz hors de la bouche; e le feloun chai abatu a la terre. E a ceo dist vne voiz en le oye de touz: "Aduersus filiam matris ecclesie ponebas scandalum; hec fecisti et tacui." E pur ceo que le rey fu pres, pur ceo ne voleit Elda iugement doner sur la tresoun iesqes sa venue; e mist le feloun en prisoun. (Trivet, 171-2)

One could scarcely hope to find a more sensational example of narrative. This is an accomplished piece of storytelling, particularly in its skilled and unobtrusive control of pacing. Trivet deploys a rapid flow of details--the nightmarish confusion of the initial discovery, the traitor knight's triumphant "revelation" of the murder weapon, the blasphemous haste with which he swears on the gospels, the grisly particulars of his miraculous punish- 
ment--so as to create a headlong and tumultuous sequence of events brought to an equally swift and decisive resolution by divine intervention. The narrative calls little attention to its own style; rather it focuses on events themselves, and seems designed to evoke a pleasurable sense of excitement, suspense, and happy reassurance that justice has been served.

Chaucer's version of the same episode is of course longer (roughly 725 words in comparison with Trivet's 350); its augmentations are not, however, as Block would have it, intended to flesh out Trivet's skeleton of a tale with further dialogue, psychological motivation, or local color. Rather the narrator's technique here, as elsewhere in the tale, is twofold: he eliminates and suppresses any material which distracts the reader from Constance and her plight, and he inserts commentary intended to direct and stir the reader's emotional response to the heroine. The discovery of Hermengyld's body, which occupies the first half of the Trivet passage, is in the Man of Law's Tale compressed to a mere five and a half lines:

Soone after cometh this constable hoom agayn, And eek Alla, that kyng was of that lond, And saugh his wyf despitously yslayn, For which ful ofte he weep and wroong his hond, And in the bed the blody knyf he fond By Dame Custance. Allas! what myghte she seye? For verray wo hir wit was al aweye. (B $603-9)$

The remaining line and a half, required to fill out the stanza, 
brings the reader's vision squarely to rest on Constance--and on her helpless victimization, her inability to act on her own behalf. This tendency to render her less an agent and more the object of narrative commentary continues in the oath-sequence, where the thrilling recklessness of Trivet's traitor-knight is replaced by a ceremonially staged judicial ordeal. The differing conception of narrative pace implied by these revisions is crucially typical of the tale's overall procedure. In place of Trivet's emphasis on rapid circumstantiality, the more static Chaucerian scenario invites the narrator and his audience to brood upon Constance's situation:

For as the lomb toward his deeth is broght, So stant this innocent bifore the kyng.

This false knyght, that hath this tresoun wrought Berth hire on hond that she hath doon thys thyng. But nathelees, ther was greet moornyng Among the peple, and seyn thay kan nat gesse That she had doon so greet a wikkednesse;

For they han seyn hire ever so vertuous, And lovynge Hermengyld right as hir lyf. Of this baar witnesse everich in that hous, Save he that Hermengyld slow with his knyf. This gentil kyng hath caught a greet motyf Of this witnesse, and thoghte he wold enquere Depper in this, a trouthe for to lere.

$$
\text { (B } 617-30)
$$

In short, Trivet's convergence of rapid, varied actions is transformed into a still image whose true dynamic is the inward struggle of the heroine and her sympathetic narrator. An adven- 
ture becomes a scene of pathos. One possible way to understand Chaucer's revision is to note that it apparently lends the episode greater formal congruence with the hagiographic scenario: in refusing sexual victimization, Constance becomes subject to judicial persecution, from which she is rescued by a miraculous revelation of divine power and favor. Yet this formal congruence cannot entirely explain the scene's peculiar effect. Instead of making the tale's events more fully intelligible, it creates a particularly intriguing set of tonal discrepancies between this scene and a canonical passio.

Chaucer does not, for instance, lend his heroine the saint's perfect indifference to circumstance; instead he emphasizes, as Trivet does not, her "verray wo" ( $B^{1}$ 609). Even more marked and significant is the very un-hagiographic depiction of the observers' responses. Constance herself relies on divine assistance (see Farrell for a discussion of this "help of God" motif; and Yunck 254-5 on its appearance in hagiographical contexts). Those around her are less sanguine, and this crowd of sorrowing witnesses is of course reminiscent of the observers at the trial and passion of the martyr. Yet their "greet moornyng" seems inconsistent with the real situation, which is, after all, an inquest rather than an inquisition. Alla, whose role in this scene ought to correspond to that of the wicked prefect in the typical passio, 
is filled not with irrational rage, but with a becoming sympathy for his victim: "This Alla kyng hath swich compassioun, / As gentil herte is fulfild of pitee, / That from his eyen ran the water doun" ( $\mathrm{B}^{1}$ 659-61). The variant here on Chaucer's oftrepeated remark that "pitee renneth soone in gentil herte," with its implied appeal to a common bond of sentiment and civility, points up the peculiarity of the scene when we view it from the hagiographer's perspective: though the narrator labors to create a dramatic atmosphere of tension and peril, the customary sources of pity and terror--pagan depravity, sadistic tortures, forced apostasy--are altogether absent. Indeed, the threat to Constance's well-being is entirely prospective, and perhaps only notional, for whereas the virgin-martyr opposes the full force of a corrupt and morally indifferent civil authority, Chaucer's heroine faces a just and sympathetic tribunal. Hence it is all the more interesting that the narrator holds up their grief as a response fittingly in accord with his own anxiety and pity.

Allas! Custance, thou hast no champioun, Ne fighte kanstow noght, so weylaway! But he that starf for our redempcioun, And boond Sathan (and yet lith ther he lay), So be thy stronge champion this day! For, but if Christ open miracle kith, Withouten gilt thou shalt be slayn as swithe.

She sette hire doun on knees, and thus she sayde:

"Immortal God, that savedest Susanne Fro false blame, and thou, merciful mayde, Marie I meene, doghter to Seint Anne, 
Bifore whos child angeles synge Osanne, If I be giltlees of this felonye, My socour be, for ellis shal I dye!"

$$
\text { (B } 631-44)
$$

In the stanzas that follow the audience is even invited to project its own emotions upon Constance:

Have ye nat seyn somtym a pale face, Among the prees, of hym that hath be lad Toward his deeth, wher as hym gat no grace, And swich a colour in his face hath had, Men myghte knowe his face that was bistad, Amonges alle the faces in that route?

So stant Custance, and looketh hire aboute.

O queenes, lyvynge in prosperitee, Duchesses, and ye ladyes everichone, Haveth som routhe on hire adversitee! An Emperoures doghter stant allone; She hath no wight to whom to make hir mone. O blood roial, that stondest in this drede, Fer been thy freendes at thy grete nede! (B $645-58)$

Thus while the episode gestures towards the formal structures of the canonical passio, its moral image of virtue in distress is quite unhagiographic. The scene does conclude with a miracle, but Constance's charismatic effect does not derive from her transformation into a living instrument of divine justice; instead it is based on her capacity to evoke human, creatural pity. Finally the scene's energies are dedicated towards forging an inclusive, imaginative community of feeling, with the image of Constance's pale, beleaguered face as its contemplative source and focus. And this community is created above all by the narrator's 
deployment of rhetoric as a guide to reader response.

The reader of a passio is typically incited to feel reverence for the divine power manifest in sainthood, and greater devotion for the saint whose cult the legend commemorates. Significantly, however, the reader of the Man of Law's Tale is explicitly urged towards a very different set of emotions: pity, indignation, and above all a kind of anxiety or suspense that is utterly foreign to the perfect equanimity which animates the Second Nun. Constance's exemplary value and figural significance have been well explicated and defended, especially by V.A. Kolve (Kolve, $\underline{C}$ and the Imagery, Chapter VIII; see also Stephen Manning, "C's Constance"): her very name reveals her function as a living image of the appropriate human response to the world's evils, misunderstandings, and brute vicissitudes. The narrator's commentary on this essentially homiletic material, however, largely ignores her possible function as a reassuring figure of virtue triumphant. Instead it employs her as the catalyst for a kind of hand-wringing dread. His rhetorical manner relies heavily on those figures--exclamatio, apostrophe, imprecatio--which were regarded by rhetoricians as particularly suited to stirring the emotions (Vickers 137; Bestul 217-20). Indeed, as Walter Scheps has shown, apostrophe is common throughout the pathos group, but is exceptionally prevalent in the Man of Law's Tale (Scheps 290, 
293).

This kind of rhetoric would seem to confirm the theory that Chaucer sought to produce a generally more vivid and moving narrative. But the tale's affective intensity is not at all general; indeed, it is of a very particular and restricted kind, as we can see by comparing another Chaucerian passage with its source in Trivet. The Anglo-Norman version of Constance's reunion with Alla is spare, but can scarcely be called restrained:

A ceo le roy demanda del juuencel soun noun. E il respoundi qe son noun fu Moris. Dount le rey deuynt en grant pensee, e del noun e de la resemblaunce de visage, e pur le dis le senatour; e demaunda del senatour si ly plust fere moustraunce de la dame, la mere de juuencel. E il lui respoundi qe ele estoit en sa mesoun. Sur ceo le rey, trop conforte, fist hastier le manger. E quant yl estoit descendu al paleys le senatour, parust sa femme, qe ly venoit encountre oue la femme le senatour. E ly rois, apres qil auoyt la dame del paleys salue, par certeyne conisaunce ala sa femme enbracer e beser. E taunt apert moustraunces damour ly fesoit, que le senatour e la dame e quantqe i esteint, ne esteient pas poi merueilez. E le rey a ceo, tut en haut escrie: "Jeo ay troue ma femme!" (Trivet 179)

Once again we see that pacing is Trivet's particular strength as a narrator. The scene's strategy of pleasurable delay, as Alla grows more and more certain of the truth which Constance and the audience already know, ends in an almost Shakespearean triumph of recognition. The corresponding passage in the Man of Law's Tale, however, shifts the center of interest from Alla to--predictably enough--the heroine: 
Now was this child as lyk unto Custance As possible is a creature to be.

This Alla hath the face in remembrance

Of dame Custance, and ther on mused he

If that the childes mooder were aught she That is his wyf, and pryvely he sighte,

And spedde hym fro the table that he myghte.

"Parfay," thoghte he, "fantome is in myn heed!

I oghte deme, of skilful juggement,

That in the salte see my wyf is deed."

And afterward he made his argument:

"What woot I if that Crist have hyder ysent

My wyf by see, as wel as he hire sente

To my contree fro thennes that she wente?"

And after noon, hoom with the senatour

Goth Alla, for to seen this wonder chaunce.

This senatour dooth Alla greet honour,

And hastifly he sente after Custaunce.

But trusteth weel, hire liste nat to daunce,

Whan that she wiste wherfore was that sonde;

Unnethe upon hir feet she myghte stonde.

Whan Alla saugh his wyf, faire he hire grette,

And weep, that it was routhe for to see;

For at the firste look he on hire sette,

He knew wel verraily that it was she.

And she, for sorwe, as doumb stant as a tree,

So was hir herte shet in hir distresse,

Whan she remembred his unkyndenesse.

Twyes she swowned in his owene sighte;

He weep, and hym excuseth pitously.

"Now God," quod he, "and alle his halwes brighte

So wisly on my soule as have mercy,

That of youre harm as giltelees am I

As is Maurice my sone, so lyk youre face;

Elles the feend me fecche out of this place!"

Long was the sobbyng and the bitter peyne, Er that hir woful hertes myghte cesse;

Greet was the pitee for to heere hem pleyne, Thurgh whiche pleintes gan hir wo encresse. I pray yow alle my labour to relesse; 
I may nat telle hir wo until to-morwe,

I am so wery for to speke of sorwe.

(B $1030-71)$

The emphasis upon the prolonged character of their weeping is characteristic of the tale's amplificatory strategies. Most remarkable, however, is the importance which the scene places upon the characters' anxiety. Trivet's account produces an expectation of pleasurable closure; the dramatic irony of Alla's ignorance contributes to our participation in the tale's imminent happy resolution. Chaucer, by contrast, emphasizes Constance's fear of further persecution at the hands of a husband whose loving intentions she does not yet know. The audience, of course, has long been aware of Alla's innocence and desire to recover his family. Where Trivet makes the king the focus of a joyous surprise which Constance herself has engineered, Chaucer makes Alla, by virtue of the knowledge which he shares with the audience, one more instrument in the story's sequence of threats against the heroine. Like the trial scene, though in less elaborate fashion, this recognition depends for its effect on prolonging and intensifying a basically illusory atmosphere of peril and apprehensiveness.

In general, then, the Man of Law's Tale handles the events of early Christian history in a way quite unlike its source: its recurrent extended commentary establishes a pattern of stop- 
action and close-up, of recapitulation and retardation, which lends the tale its characteristic rhythm. In accordance with this sort of pacing is the narrator's attitude toward his story's persons and events. Amplificatio in the Man of Law's Tale works, perhaps paradoxically, to restrict and intensify the array of possible audience response. Chaucer's revisions forestall any narrative excitation not directed at Constance herself (as when he reduces Trivet's detailed description of Donegild's execution to a mere mention), and consistently recast Constance as instrument rather than agent (as when he eliminates the clever ruse whereby Trivet's Constance outwits and defeats her would-be rapist). This formal technique for creating a particular sort of suspense seems closely related to some of the tale's recurrent preoccupations. It suggests, for instance, one meaning for the tale's continual resort to astrology, a science which itself often takes an inconsistent attitude towards the future: the astrologer's belief in the stars' determining influence breeds not resigned acceptance, but a redoubled effort to discern the future so as to avoid it. When, for instance, the narrator complains of the "infortunat" ( $\mathrm{B}^{1}$ 302) astral configuration at the time of Constance's departure for Syria, he creates a tension between the tale's didactic emphasis on faithful acceptance of circumstance, and a more natural (and rhetorically more vivid) wish to squirm 
out of the dictates of providence. Similarly, when Constance stands accused of the murder of Hermengyld, the narrator emphasizes her peril and remarks that "but if Christ open myracle kithe / Withouten gilt thou shalt be slayn as swithe" ( $B^{1} 636-7$ ). The implication seems to be--in defiance of the tale's past events and generic requirements--that a miracle is the least likely sequel. Astrology thus offers a convenient analogue to the narrator's own ambivalence toward his heroine, whom he evidently wishes to depict as simultaneously victimized and protected, terrorized and yet also serenely faithful.

The tale's tone, in keeping with its emphasis on peril and suspense, ranges narrowly from the rueful to the lugubrious. Mundane joy has its place in Trivet's chronicle, but not in Chaucer's; both of Constance's wedding celebrations are dismissed as irrelevant to the story's real purpose:

And thus in murthe and joye I lete hem dwelle; The fruyt of this matiere is that I telle. (B $410-11$ )

Me list nat of the chaf, ne of the stree, Maken so long a tale as of the corn... The fruyt of every tale is for to seye: They ete, and drynke, and daunce, and synge, and pleye.

$$
\text { ( } \mathrm{B}^{1} 701-2,706-7 \text { ) }
$$

This attitude is in some respects fitting, of course, since disorder and misfortune constitute the tale's narrative and philosophical point of departure. It is certainly worth noting, 
however, especially given the tale's extraordinary and even miraculous sequence of events, the degree to which the narrator pitches his audience appeals at the level of common, everyday emotional experience ("Have ye nat seyn somtym ... ?" [B $\left.{ }^{1} 645\right]$ ). While both Trivet's chronicle and the traditional saint's legend dramatize the extraordinary, almost inhuman image of a Christian sustained by grace, Chaucer's narrator is fascinated by a more daily sort of suffering. Indeed, he ultimately seems skeptical of our capacity to transcend worldly unhappiness, whether by Boethian forbearance or by Christian faith. Near the close of his tale he suggests, in a passage borrowed from Innocent III's De miseria humane conditionis (itself a work of unrelenting pessimism) that inward discomfiture, like outward disaster, is intrinsic to the human condition:

But litel while it lasteth, I yow heete, Joye of this world, for tyme wol not abyde; Fro day to nyght it changeth as the tyde.

Who lyved euere in swich delit o day That hym ne moeved outher conscience, Or ire, or talent, or som kynnes affray, Envye, or pride, or passion, or offence? I ne seye but for this ende this sentence, That litel whil in joye or in plesance Lasteth the blisse of Alla with Cystance. (B) $1132-41$ )

Thus the dispositio of the Man of Law's Tale seems to run counter to its underlying narrative shape. The tale's substruc- 
tures are historical and hagiographical topoi which characteristically leave little room for anxiety or doubt on the audience's part: we do not tremble lest Margaret be swallowed by the dragon, lest Catherine's Christian eloquence fail her at the critical instant, or lest Agnes be defiled in the brothel. Our natural trepidation concerning such situations, like our distress at the martyr's dismemberment, is finally revealed to us as a spiritual limitation which the narrative helps us to master and contextualize. The saint's legend thus forges a readerly community based on faith in the possibility of divinely perfected human nature. The Man of Law's Tale, on the other hand, invokes a community of radically creatural experience; it invites its audience to participate in a meditation, whether tender or vehement, upon the very anxiety and self-conscious pity which hagiography tries to transcend. And finally the peculiarities of the tale's spiritual vision seem inextricably linked to the rhetorical devices which so largely occupy the foreground of the tale, and which the Second Nun's. Tale so explicitly eschews.

This double point of contrast between the Second Nun's and Man of Law's Tales may, of course, simply dramatize the gap between the Second Nun's moral perfection and the Man of Law's regrettable tendency towards what Wood characterizes as "a materialistic, legalistic view of astrology, religion, literature, and 
everything else" (Wood 151). Such a conclusion must rest, however, on the certainty that style in the Man of Law's Tale really is so idiosyncratic as to be recognizable as an expression of narrative personality, and that the attitudes it expresses really are unorthodox or repellent. Neither of these claims seems to me to have been adequately demonstrated. My analysis, therefore, will pursue the question of whether the decorum of the tale is intelligible in terms of literary tradition. I will argue that indeed it is, and that the tradition on which it draws is the likeliest source for many of the tale's stylistic peculiarities.

My chief contention is that the stylistic subtext for the Man of Law's Tale is the large body of vernacular religious lyrics and gospel meditations. An approach to the aesthetic behind the Man of Law's Tale thus requires an excursion into the art and literature associated with late medieval devotional practices. We can begin, however, with the text itself, and with what is probably the tale's most celebrated stanza:

Have ye nat seyn somtym a pale face, Among the prees, of hym that hath be lad Toward his deeth, wher as hym gat no grace, And swich a colour in his face hath had, Men myghte knowe his face that was bistad, Amonges alle the faces in that route? So stant Custance, and looketh hire aboute. (B 645-51)

This simile is often taken as a quintessentially Chaucerian instance of detail drawn from life. Block includes it among his 
examples of "imaginative realism," noting approvingly that "it is altogether natural that her face would be pale--from fear, tension, and nervous apprehension" (Block 591). We rightly value such a passage for its immediacy and pictorial force. But we are probably mistaken when we also regard it as evidence of Chaucer's attempt to escape the fetters of artifice and secondhand rhetorical tradition, for the scene is not, of course, a simple case of naturalistic observation. It is a traditional scene of pathos, and as V.A. Kolve notes (Kolve, $C$ and the Imagery, 304), any audience familiar with the fourteenth-century pictorial conventions for representing Christ on the way to Calvary will instantly recognize the reference to the "pale face" of the accused.

This convention originates not in the Gospels themselves, but rather in the apocryphal Greek versions of the Gospel of Nicodemus. According to this tradition, Mary, upon learning that her son had been condemned to death, hurried to join him on the road to Calvary, but was prevented from getting near him by the crowds (Apocryphal Gospels, Acts, and Revelations, tr. Walker 1589). This episode survives in three influential medieval retellings of the passion: the Liber de passione Christi attributed to Bernard, the Dialogus Beatae Mariae et Anselmi de passione Domini attributed to Anselm, and the pseudo-Bonaventuran Meditationes. 
Vitae Christi, composed in Tuscany towards the end of the thirteenth century (Bernard, Liber; Dialogus; see Weissman, "C's Bad Tales" for a discussion of these materials). The first two are visionary dialogues in which the Virgin offers a first-hand recollection of the passion, while the third is a structured cycle of meditations on the events of Christ's life.

This last work, according to Millard Meiss, helped to inspire a newly realistic and narrative approach to the illustration of Gospel stories. Paintings in this tradition show Christ in motion along the road, his body bowed forward under the weight of the cross, yet twisting his head and shoulders backwards to regard the sorrowing Virgin who walks behind him. No doubt this contrapposto held technical interests for artists, but it also has thematic significance. Christ's gesture implies, as Meiss observes, "a moment when he is involved in two opposed interests" (Meiss 146): the physical forward momentum of the heavy cross counterbalances Christ's no less weighty emotional impulse to turn back and comfort his mother. The twist in Christ's body also permits the image to acquire iconographic significance: Christ's head rotates from a profile to a three-quarter or frontal angle, so that his visage, framed with a heavy gilded halo, becomes a sudarium or holy face inserted directly into the center of the composition. Whatever the rationale for the motif of the backward 
look, its most salient characteristic is the absolute centrality and isolation of Christ's nimbed face: starkly pale and filled with an enigmatic anxiety, it seems to float in almost detached fashion out of the hubbub of the surrounding scene. This scene of pathos is thus both a genre scene and an icon. It reminds the viewer of the facts of sacred history, it reinforces, through its reference to the sudarium, his veneration of holy images, and it invites, through its intensely humanized presentation, his meditation on the collective spiritual significance of what is represented.

This version of the road to Calvary develops in the Italian Trecento. Notable examples were produced by Giotto (1305, in the Arena Chapel, Padua), Andrea da Firenze (c. 1366-68, in the Spanish Chapel of Santa Maria Novella, Florence, reproduced in Meiss, figure 38), Barna (1350-55, in the Collegiata, San Gimignano; reproduced in Meiss, figure 76), and Simone Martini, whose way to Calvary painted c. 1340 at Avignon (now in the Louvre; reproduced in Meiss, figure 75) seems to have considerably influenced French treatments of this subject, notably that of the Limbourg brothers in the Très Riches Heures of Jean, Duke of Berry (141316; reproduced in the edition of Longnon et al. plate 111). More northerly instances of the motif include Jean Pucelle's exquisite illumination in the Hours of Jeanne d'Evreux (1325-28, now in the Cloisters; reproduced in Avril, plate 5), and a version by his 
follower, perhaps Jean le Noir, in the Hours of Yolande of Flanders (1350-55, now British Library MS Yates Thompson 27; reproduced in Avril, fig. viii). Towards the end of the fourteenth century we find the same motif in the left wing of the anonymous grisaille-on-silk hanging known as the Parement de Narbonne (c. 1375, now in the Louvre; reproduced in Avril, fig. xiii). The motif survives well into the renaissance and finds powerful expression in the works of Dürer (reproduced in Kurth, figure 96). Kolve notes Chaucer's reference to this motif only in passing, remarking that while "late-medieval images of Christ carrying the cross to Calvary may well come to mind ... there should come to mind with even greater force the remembered face of any criminal accused by a crowd on his way to the gallows" (Kolve, $\underline{C}$ and the Imagery, 304). The precise specificity of the association between Constance and Christ, however, is clear: the pseudoAnselmian Dialogus refers to Christ in exactly the terms Chaucer uses to describe Constance's situation: "Tota turba concurrebat, sicut quando fures ducuntur ad supplicium" (PL 159:281). I would argue more strongly, therefore, for the importance of the apocryphal Gospel episode and its pictorial associations.

The pale face stanza is just one of a cluster of references to visual tradition in the Man of Law's Tale. Kolve has exhaustively documented the rich meanings associated with the tale's 
dominant image, the ship at sea. To this one might add the narrator's description of the Sultaness as a "serpent under femynynytee" ( $\left.B^{1} 360\right)$, surely a reference to the traditional motif of Satan tempting Eve in the guise of a serpent with a woman's head. Less explicit but far more important in the tale is the comparison of Constance and Maurice to the Virgin and Child. Weissman argues that Constance's farewell before being set adrift for the second time recalls the "pathetic Nativity" (Weissman, "Late Gothic Pathos" 148-52); my own intuition is that the relevant image is rather the Madonna of Humility, in which the Virgin sits or kneels on the ground, the Christ-child lapped in her mantle (see figures 128-56 in Meiss for representative examples of this motif).

These references to visual conventions for representing Scriptural subjects are noteworthy. As Kolve demonstrates, they link the tale's characters to sacred figures from Biblical narrative, thus achieving a characteristically medieval set of typological resonances between the present and th past. More importantly, however, the references to specifically devotional motifs such as the Madonna of Humility or the way to Calvary offer evidence of a representational tradition common to both images and texts. They are, I suggest, a fruitful approach to the problem of style in the Man of Law's Tale. 
As Meiss notes, late medieval devotional literature, like the arts of the period, depends on a stop-action technique in which the familiar events of Gospel narrative are slowed, amplified, or relegated to a background against which the sacred portrait stands out, inviting the viewer's long contemplation:

Both emerge by similar transformations from a similar context of narrative art: the devotional picture by isolating a figure or two from the distractions of narrative action, the [literary] monologue or colloquy by suspending the narrative for the more expanded utterance of the participants. (Meiss 127)

This analogy offers an initial explanatory model for the Man of Law's Tale's perplexing amalgam of homely emotion and rhetorical extravagance. The modern impulse to dismiss this characteristic as vulgar and/or naive ought to be considerably dampened when we consider the above-mentioned visual images, whose remarkable textural effects of stasis against dynamism obviously bespeak no small degree of artistic sophistication. Many devotional images were of course modest artifacts designed strictly for private use, but the works I have cited were all important commissions intended to embody, in splendidly ostentatious form, the piety, wealth, and social status of their patrons. We may ourselves regard the very personal and even domestic quality of the emotions portrayed--filial regret, motherly tenderness, all-too-human grief--as inappropriate to the public context of such artworks. But we 
should hesitate to label their effect as merely sentimental. Certainly they imply an eruption of ordinarily private experience into the sphere of civic and dynastic life, but this outpouring is clearly and even conventionally contained by a controlled vocabulary of gesture and by highly-wrought technique.

The resemblance between late medieval visual arts and certain kinds of contemporary literature is obvious. As Rosemary Woolf has shown, similar features--a "close-up" focus, an implied connection to Biblical narrative, and a lavishly rhetorical treatment of human passions--also characterize the late medieval devotional lyric. Equally strong parallels exist to the somewhat less well-known body of gospel meditations like the Latin Meditationes vitae Christi, which spawned various vernacular redactions (the Latin text is included in Vol. XII of Sancti Bonaventurae Opera Omnia, ed. A.C. Peltier; also available is an Italian redaction translated into English by Ragusa and Green). The earliest English version of the Meditationes is a partial translation made early in the fourteenth century by Robert Manning, but by far the most popular is that of Nicholas Love (made before 1410, surviving in 23 manuscripts, and printed four times between 1488 and 1523). There is every reason to believe that devotional texts and devotional images evolved in tandem. In examining the development of the English religious lyric, for instance, Woolf 
finds it significant that the later poems include considerably less descriptive detail:

Often the meditative picture is only alluded to in the text, and is supplied in detail by an accompanying illustration or by a rubric referring the meditator to a statue or painting in church. It is difficult now to disentangle the historical development here, and to know what initially was cause and what effect: whether it became customary to provide a meditative illustration because the poems themselves had become so bare of detail, or whether a custom of providing illustrations led to visual descriptions becoming redundant within the poems, But, whatever the beginnings were, it seems clear that the ampler supply of devotional representations in churches, and in books of hours and other manuscripts, led during the course of the fifteenth century to an author's assuming that his readers would gain knowledge of a visual image, not from a literary description provided by himself, but from a statue or painting, and that ideally an illumination would actually accompany the poems in the manuscript. (Woolf 183-4)

The linking factor in this proliferation of texts and images, of course, is the late medieval devotional habits which the new religious arts were designed to serve. The greater emphasis within the church, from the late twelfth century onwards, on pastoral care and on the spiritual condition of the individual is well known, as is the resultant interest among laypeople in such essentially solitary activities as examination of conscience, private prayer, and meditation. Images, once only the libri laicorum, were now expected to inspire as well as inform, and the relatively free exercise of the emotions and imagination became an important component of piety. Love's Prohemium (following pseudo- 
Bonaventure's) reflects this shift; it defends the value of meditation on the life of Christ in terms that set it apart from public, liturgical forms of worship:

For among alle gostly exercises I leue that this is most necessarye and most profitable; and that may brynge to the hi3est degre of good lyuyng / that stant specially in perfite despisynge of the world / in pacience suffrynge of aduersitees / and in encres and in getyng of vertues. For sothely thou schalt neuere fynde where man may so perfi3tly be tau3t: First forto stable his herte a3enst vanytees and disceyuable likynges of the world; also to strengthe hym amonge tribulaciouns and aduersitees; and furthermore to be kept fro vices and to getynge of vertues / as in the blissed lyf of our lord Jesu / the whiche was euere with oute defau3te moste perfyte. .. Wherof han martires her strengthe a3enst dyuerce tourmentis / bot/ as seynt Bernard seith / in that they setten all her herte and deuocioun in the passioun and the woundes of criste? For what tyme the martir stant with al the body to rent / and neuertheles he is ioyful and glad in all his peyne; where trowest is than his soule and his herte? Sothely in the woundes of Jesu. 3e / the woundes not closed / bot open and wyde to entre ynne: and elles he schulde fele the hard yren and not mowe bere the peyne and the sorwe / bot sone faile and denye god. (Love 10-11)

This passage is remarkable for its exclusion of any soteriological considerations. Instead it makes an explicit equation between sacred passion--that of Christ and the martyrs--and the reader's own daily trials of virtue. Christ's salvific function is imagined in present-day terms: he inhabits the passage chiefly as an eternally suffering man of sorrows or crucifix, whose wounds, envisioned as a literal, corporeal locus of protective 
grace, offer the devoté a kind of safe haven. Love's rehearsal of sacred history could hardly depart more decisively from the hagiographer's task of reinforcing the public, corporate life of a historically-fulfilled Church triumphant. This alternative view of meditative edification appears clearly in his treatment of the Sermon on the Mount: he will omit any retelling of Christ's actual discourse, "for as moche as it is writen bothe in latyn and in englische in many othere places; and also it were ful longe processe to touche alle the poyntes thereof here as by manere of meditacioun" (Love 109). The word "processe" here, with its connotation of a mechanical or otherwise formally dictated procedure, is revealing, as is his own re-vision of the episode as a sermo without words, an ekphrasis which emphasizes not doctrine, but rather Christ's charismatic presence:
But now leuying this matere torne we vs to the manere of contemplacioun / byholdinge oure lord Jesu hou lowely and mekely he sitteth vppon that hille and his disciples aboute hym / and with hou louely and sad chere he spekith tho wordes ful of edificacioun / and techeth that noble lessoun of souereyn perfec- cioun; and also how entently his disciples byholden his blissed face / and heren the swete wordes / and setten hem besily in her mynde: and so haue they grete ioye and gostely likynge / bothe in his speche and in his si3te. (Love 110-111)

Where the hagiographer displays a spectacular vera icon of divinity, Love offers a domesticated image of God. The disciples' "grete ioye and gostely likynge" images the devoté's own desire 
for a more direct, intimate, and familiar relation to the sacred, while their looking "ententely" and working to absorb his words "besily in her mynde" suggests that certain truths about the scene are available only through minute, introspective attention to the subtle details of the imagined experience. This emphasis on private interpretation of the spectacle is, I think, an activity closely allied with Love's own literary recreation of sacred history.

The poetic quality of meditation is important. Yet all students of late medieval devotional literature also stress its connection to extra-textual religious practices (e.g., Woolf; Wenzel, Verses; Wenzel, "Poets"; Bennett). Late medieval art and literature are not simply influenced by late medieval religion; in fundamental ways they are an actual manifestation of it. What Douglas Gray says of the authors of devotional lyrics is equally true of devotional painters: "They are not primarily concerned with the construction of an enduring object for other people to admire, but rather for other people to use" (Gray, Themes, 60). One might reasonably ask, therefore, what kind of religiosity Love's Mirrour reflects. His image of Jesus on the mount as neither prophet nor incarnate god is potentially troubling. Divinity ought, after all, to remain distinct from mere human attractiveness. The believer's vision of the bleeding Christ ought to 
inspire not just sympathy, but some intimation of theophany. Insofar as love's gospel meditations encourage a certain domestication of sacred history, they necessarily lose something of the authentic, sacramental character so crucial to the saint's legend. Love delicately addresses this very issue, also in the Prohemium:

Wherefor it is to vndirstonde at the bygynnynge as for a principal and general rule of dyuers ymaginaciouns that folowen after in this book / that the discryuynge or speches or dedes of god in heuene and angeles and other gostly substaunces ben only writen in this manere and to this entente / that is to seie as deuoute ymaginaciouns and liknesses stirynge symple soules to the loue of god and desire of heuenly thynges. For / as seint gregory seith / therfore is the kyngdom of heuene lickened to erthely thinges: that by tho thinges that ben visible and that man kyndely knoweth / he be stired and rauysched to loue and desire gostly invisible thinges that he kyndely knoweth not. (Love 9)

Love's scrupulous effort to place his work in the realm of "ymaginaciouns and likenesses" suggests his full awareness both that meditation is a private, creative process, and also that it is no substitute for dogma or public worship. The "dedes of god in heuene and angeles and other gostly substaunces" are revealed to humankind first and foremost through the sacramental agency of Scripture and liturgy. He emphasizes, in short, the strictly personal utility of meditation, and also its radical contingency. These peculiarly literary qualities of meditative literature are difficult to grasp, and may best be illustrated by a brief but 
very rich example of devotional lyric. Though printed independently by Carleton Brown under the title "Sunset on Calvary," (Brown, XIIIth Cent. item \#1), the following lyric probably was first recorded, as Brown's own notes acknowledge (Brown, XIIIth Cent. 165-6), as part of a metrical prose meditation on the crucifixion in Edmund of Pontigny's Speculum Ecclesie (c. 1239-40):

Ci doit tu penser de la duce Marie de quel angusse ele estoit replenié quant estut a son destre e receust le disciple pur le mestre; cum ele avoit grant dolur quant le serf receust pur le seignur--le fiz us peschur pur le fiz al emperor--Iohan, le fiz Zebedeu, pur Ihesu, le fiz deu. Et pur ceo poeit el dire de soi ceo ke dist Neomi: "Ne me apelez bele, taunt ne quant, mes amere me apelez des or ne avant; kar de amerete e dolur grant m'ad replenie le tot pussant." Meimes cele tenuire dit ele en le chancon de amur, "Ne vus amerveillez mie que io su brunecte e haslée, car le solail me ad descolurée." E pur ceo dit un Engleis en teu manere de pite:

Nou goth sonne under wode;

Me rewes, Marie, pi faire rode.

Nou goth sonne under tre;

Me rewes, Marie, pi sone and pe.

(Edmund of Pontigny 63)

The rhetorical character of this passage's expansion on a brief Gospel incident (Jn 19:25-27) is immediately apparent. Most notable is the complex system of repetitions, parallels, and antitheses: "quant . . . quant," "X pur Y," "le fiz . . . le fiz," "nou goth . . . nou goth," "me rewes . . . me rewes," and the two identicallystructured Biblical quotations ("ne ... car"). Edmund also heightens the impact of the scene by inviting our participation and identification, partly by his use of the first and second 
persons ("me rewes," "ci doit tu penser"), but also by focusing the scenario almost entirely upon the sorrowing Virgin. This uncanonical emphasis, already familiar to us from "Stond wel, moder" and sometimes known as the compassion or co-crucifixion of the Virgin, is an important expression of late medieval Marian devotion. Here Mary herself does not speak, but elsewhere the planctus Mariae is a favorite form (see Keiser and Woolf for a survey and discussion).

A less familiar feature of the passage is the pair of references to other Biblical lamenters. The words of Naomi (the Vulgate verse is "Ne vocatis me Noëmi [id est, pulchram], sed vocate me Mara [id est, amaram], quia amaritudine valde replevit me Omnipotens" [Ruth 1:20]) makes a figural equation between Old and New Testament sufferers; the quotation from the Song of Songs ("Nolite me considerare quod fusca sim, quia decoloravit me sol" [Cant. 1:5]) involves an allegorical equation in which, as St. Bernard tells us in a sermon on the Song of Songs,

to be discolored with the sun may also mean to be on fire with fraternal love, to weep with those who weep, to rejoice with those who rejoice, to be weak with those who are weak, to burn with indignation when someone is led into sin. She [the Bride] can also say this: "Christ the Sun of Justice had made me swarthy in color, because I am faint with love of him." (Bernard, Song of Songs 28:13)

The words of "un Engleis" thus draw on a complex set of associa- 
tions, manifested in the English play on "sonne" and "sone," between the literal disappearance of the sun at the time of Christ's death, and his eternal effulgence, as symbolized in the image of the sol iustitiae.

Edmund makes it perfectly clear that the sun-reference in the Song of Songs provides the exegetical pre-text for the lyric "Nou goth sonne" ("pur ceo dit un Engleis"). But modern commentary on the lyric (as on the "pale face" stanza of the Man of Law's Tale) has tended to emphasize its imagistic, mimetic quality. Edmund Reiss, for instance, detaches the poem entirely from its context and treats it as an instance of the pathetic fallacy:

We may wonder here what Mary's countenance, rode, has to do with the sunset, except that the setting sun has perhaps struck the Virgin's face at such an angle and with such a color of light that the face contains a strangeness for the narrator. But then, in the last two lines we realize that, like the sun in the sky, Mary's son is also going under, as it were, on his tree. (Reiss 317-18)

Although the notes to R.T. Davies' anthology of Middle English Lyrics at least call the reader's attention to the larger setting of Edmund's Speculum Ecclesie, including the reference to the Song of Songs, they too suggest that the poem's real context is experiential and literary rather than intellectual: the poet draws on a generalized sense of the human condition, in which the equation of death with sunset is no more than natural (Davies 310-11). George Kane recognizes the allusions chiefly so as to dismiss them 
("this circumstance in no way increases the effectiveness of the poem"); his brief, forceful analysis of the lyric shows true appreciation for its evocative qualities, but he too approaches it as a poetically transformed slice of life:

In this short lyric the fusion of devotional and creative activities is nearly complete. Its first effect is pictorial: the sun falling beneath an arm of the cross, and Mary's face, tear-stained and not beautiful now, raised to that cross. This is a triumph of selection. Two details only have been taken from a picture many times fully delineated, but they are most significant. The setting sun, the stark silhouettes against the light, the end of a long day of immeasurable unhappiness, these responses not only carry their own loads of feeling but can also set off trains of associations related to the most dramatic experience in the mind of the mediaeval Christian. (Kane 140)

One difficulty with such readings, of course, is the assumption that the poem presents a literal sunset. We cannot know the original author's meaning, but Edmund certainly intends the lyric to illustrate the darkness at mid-day which accompanied Christ's death. (One wonders how the modern response to this "sunset" might be different had Carleton Brown printed it with a less misleading title.) But the chief drawback to ignoring Edmund's exegetical context is that it favors our impression that the Biblical references are no more than "background" for the lyrical project which was the poet's real concern; in fact, of course, Edmund emphasizes the words of Naomi and of the Bride at least as much as those of "un Engleis." Furthermore, insofar as the 
two scriptural witnesses precede the English lyric, they suggest that "Nou goth sonne" does more than simply allude to Biblical reality; rather the lyric reinforces it by confirming and concretizing its relevance to the narrative situation. In this regard "Nou goth sonne" functions very much like the verses in sermons which Siegfried Wenzel has studied. Though there is no question here, as there might be in pulpit discourse, of the lyric serving as a proof text or logical conclusion, still it is more than just Kane's "fusion of devotional and creative activities." As Wenzel puts it,

to label such verses as mnemonic or 'memory verses' or aides-mémoire is rather misleading, because their function in preaching goes beyond that of helping the preacher and his audience remember the structure of a sermon or a particular point of doctrine. Their ulterior intention is to affect the will and to move; this relates them closely to the rhymed advertisement jingles and political slogans of our day, with which they share many specific purposes as well as linguistic and rhetorical devices. (Wenzel, Preachers, 116)

Thus "Sunset on Calvary" addresses a community of poetically-evoked fellow-feeling and homely experience while still maintaining complex ties to certain intellectual and formal traditions: it contrives, in a way not always apparent to modern readers, to be both conventional and immediate. Its exegetical affiliations are not simply part of some aesthetically-motivated, "creative" enhancement of the poet's personal vision; they are, on the con- 
trary, what enables his vision in the first place. This quality of conclusiveness, of coming at the end of some cognitive process on which it depends, is crucial to the effectiveness of much late medieval religious literature. The difficulty for modern readers, of course, is that this process is often implied rather than explicitly detailed. As we saw in Love's remarks on Christ's wounds and on the Sermon on the Mount, meditative texts may be very selective, omitting many doctrinal matters which elsewhere occupy center stage.

Failure to grasp the contingent nature of such texts has led, as in the case of "Sunset on Calvary," to their misapprehension. Hope Phyllis Weissman, for instance, has argued for the decadence of "Late Gothic" devotion, in which lyric emotion predominates, as "inevitably diverting the meditator's attention from the theological aim of the Creator's redemption to the emotional vagaries of the creature's response" (Weissman, "Late Gothic Pathos" 144). This charge--that such literature is "doctrinally aberrant" ("Late Gothic Pathos" 146)--seems to depend on some assumption about the proper degree of intellectual completeness and autonomy of individual texts. It seems unreasonable, however, to require self-confessed adjuncts to worship to do the work of the liturgy itself. For although the devotional lyric and the gospel meditation exclude certain important ideas, they can 
hardly be said to deny them: the planctus Mariae may, for dramatic reasons, emphasize the tragedy of the crucifixion while ignoring the coming joy of the resurrection, but this is not to say that the reader will do so. Indeed, the carefully designed devotional schedule which forms the program of the Meditations should suggest the degree to which such spiritual exercises remained well within the compass of more traditional and less personalized worship. Far from neglecting doctrine, such activities should lead, through a regulated catharsis, back to the transcendently intellectual paradoxes of Pauline theology:

Loo now how hongeth oure lorde on the crosse dede / and all that grete multitude goth awaie toward the citee; and his sorwful moder / with the foure forsaide felawes / sette her downe byside the crosse / and byholdeth pitously her dere sone so ferde with / and abideth helpe fro god that sche my $3 t$ haue hym to her and burie hym. Than also if thou byholde wel thy lorde thou my3te haue here mater i-now of hy3e compassioun / seying hym so turmented that fro the sole of the foote in to the hi3este parte of his heued there was in hym none hole place ne membre withoute passioun. This is a pyteful si3t and a ioyful si3t; a pyteuouse si3t in hym for that harde passioun that he suffrede for oure sauacioun: but it is a likyng si3t to vs for the matere and the effecte that we haue therby of oure redempcioun. Sothely this si3t of oure lorde Jesu hangynge so on the crosse / by deuoute ymaginacioun of the soule is so deuoute to some creatures that after longe exercise of sorwefull compassioun thay felen some tyme so grete likynge / nou 3t only in soule but also in the body / that thay kan not telle / and that no man may knowe but only he that by experience feleth it; and than may he wel say with the apostle: Michi autem absit gloriari nisi in cruce / Betide me neuere forto be ioyful but in the crosse of oure lord Jesu. (Love 243-4) 
The relevance of the texts we've been examining should now be clear: their decorum is, in many ways, that of the Man of Law's Tale. Chaucer adopts many of the same representational strategies found in fourteenth-century devotional literature and art. What is particularly curious and interesting, however, is that Chaucer borrows an iconic style in order to depict an essentially secular heroine. That is, although divine protection clearly attends Constance throughout, her virtues are, as her name suggests, predominantly moral rather than supernatural. Yet the tale adapts a rhetoric traditionally reserved for divine and semidivine personages. This fact, I think, is at the root of some of the effects which recent readers have perceived as satiric or ironic.

By far the most interesting and problematic result of Chaucer's stylistic borrowing arises from something we noted in the Marian stanzas of "Stond wel, moder": the tendency of devotional authors to deliberately assume a sharply limited perspective on the events of the passion. Hagiographic narrative is dedicated to demonstrating the saint's holy nature; hence suffering is visibly transformed into triumphant impassibility. Christ's divinity is, presumably, not at issue, and so his suffering requires a less explicitly tendentious treatment. Characteristically in late medieval passion narrative the emphasis is not on the coming redemp- 
tion, but on the pathetic, unmerited sufferings of Christ and his mother: one might almost say that such texts present a hagiographic scenario told entirely through the eyes of one of the grieving onlookers. The effect is often obnoxious to modern readers, though it is sometimes difficult for us to distinguish, as in the following lament for the Virgin in Manning's version of the Meditations, our distaste for the rhetoric from our alarm at the eccentricity of the sentiment expressed:

AA, wrong! aa, wo! aa, wykkednes! To martyre here for here mekenes. pe sone was dede he felte no smerte, But certes hyt perced pe modrys hert bey wounded here, and heped harm vp on harmes; She fyl, as for dede, yn maudeleyns armys. A! Ihesu, bys dede ys wundyr to me, bat pou suffrest by modyr be martyred for be. (Manning, Meditations 861-8)

One can scarcely tell whether this passage is an instance of selfconsciously daring paradox, or simply of naive hyperbole. Rosemary Woolf's discussion of the Marian poems is highly conscious of how this particular problem is implicit in late medieval lyricism. In the most appealing lyrics, she argues, one finds a "balancing of distress with faith and with modesty, so that the Virgin should not be shown abandoned to the kind of unrestrained lamentation that would have been considered morally reprehensible and socially indecorous in any Christian" (Woolf 241). The issue is not simply one of artistic propriety; it also, as 
in the saint's legend, emphasizes the spiritual problem of the gap between the meaning of suffering and its mere appearance, of the gap between divine and human understanding. The author's attitude towards that gap, however, is one criterion for differentiating meditation and hagiography. In the brief introduction to the pseudo-Anselmian Dialogus, Mary herself comments on her own inability to "identify" properly with her past miseries: "Tanta et talia passus est dilectus filius meus, quod nullus sine lachrymarum effusione dicere potest. Tamen, quia glorificata sum, flere non possum: ideo tibi passionem mei filii per ordinem explicabo" (Dialogus, PL 159:271; similarly in Bernard, Liber, PL 182: 1134). The reflexive, creatural response to observed suffering, treated in hagiographical texts as an indication of worldly, unsanctified vision, is here alluded to matter-of-factly as a feature of life this side of eternity. The same acceptance of human limitation also appears in Love's instructions for meditating on Christ's passion. He recommends that the reader strive to disregard what we have already seen is one of the key characteristics of the holy martyr, namely his or her divinely-inspired impassibility. Instead the devoté should cultivate a natural perspective:

At the begynnynge thou that desirest to haue sorwefull compassioun / thoru3 feruent inward affeccioun / of the peynefull passioun of Jesu / thou moste in thy mynde depart in manere for the tyme the my3t of the godhede fro the kyndely infirmyte of the manhede; 
though it so be in sothenes that the godhede was neuer departed fro the manhede. For there beth many so blynded gostly by vnresonable ymaginacioun of the my3t of the godhede in Jesu / that thei trowe not that eny thyng my3te be peynefull or sorwful to hym as to another comune man that hath only the kynde of man; and therfore haue they non compassioun of the peynes that he suffrede / supposynge that for also moche as he was god there my3t no thing be a3enst his wille or dere hym. (Love 216)

Thus there is every reason to think that the original authors and audiences of late medieval devotional texts were fully aware of the spiritual and aesthetic problems inherent in the psychic drama of a devoté invited to brood on holy suffering. Sometimes the difficulty is resolved within the work itself, as when Christ himself admonishes his mother against despair, or when, in a particularly interesting and complex example, Dunbar's "Amang thir freiris within ane cloister" chronicles the meditator's own spiritual movement from compassion to contrition (Dunbar 27). Just as often, however, we should assume that the audience would be recalled to doctrinal norms not by the process of meditation, but by the omnipresent cultural pressures of Christianity itself.

Indeed, texts of the kind we have been examining seem remarkably tolerant of the apparent paradox in any attempt to appreciate the crucifixion as simultaneously tragic and triumphant. Manning's Meditations, for example, contain some particularly extensive and florid passages of Marian lament ("Wuld god 
3e wulde byrye me with hym! / For ban shulde we neuer departe atwyn" [999-1000]). Yet only a few lines later, with no apparent sense of discontinuity or dramatic impropriety, the author gives us the equally impressive spectacle of the Virgin offering sober, impeccable words of consolation to the disciples:

Dysmay 3ow nat for my sone Ihesus, For pus to hys dep he wulde be bore, To saue mannes soule pat was forlore; parto he com with moche stryfe, Yn traueyle and yn pouert to leden hys lyfe. No wundyr bogh $3 e$ forsoke hym yn hys ende, Hys fadyr forsoke hym socour to sende; Hymself he forsoke for oure mys dede; Y preyd for hym, y my3t no byng spede; Certes y am sory for hys grete passyun, But truly y glade for soules saluacyun; bey shulden yn helle for euer be forlore, But y hym to bys dep had hym bore.

(Manning, Meditations 1090-1102)

It is not, therefore, altogether accurate to characterize late "Gothic" devotion as displaying "egocentric pity" and as "contradicting the entire moral economy of the canon" (Weissman, "Late Gothic Pathos" 144, 146). Rather, just as apocryphal gospel stories flourish in the lacunae of Scripture, enriching it without supplanting its authority, so late medieval habits of private prayer arise to fill a previously unoccupied area of extra-liturgical piety. Indeed, it would be more appropriate to say that without the "moral economy of the canon" such texts and ways of thinking could scarcely exist. The sorrowing Virgin becomes a 
worthy object of such fervent compassion not simply because she suffers, but because she facilitates, both artistically and doctrinally, a human approach to the firm and unchallenged center of Christianity's greatest miracle. As Lee Patterson has argued, one essential generic rationale behind the planctus is that the speaker has reached an experiential dead end, a never-to-be-altered despair in which the only possible action is the utterance of the poem itself (Patterson 708-9). In the case of the planctus Mariae, however, our knowledge of the coming resurrection surrounds and contains the Virgin's grief, lending it poignance even while exposing its limitations. The devotional lyric and the passion meditation tend, therefore, to be ironic in the fullest sense of the term, and yet to validate the literary expression of sorrow by lending it an appropriately circumscribed psychological arena. As the anonymous author of a late fourteenth-century meditation on Christ's passion says,

What tyme I rede bat bok a-ry3t panne am I glad, ioyful, and ly $3 t$; Whan I speke of pat kyng so fre I mot nedes ioyful be; But whan I benke hou he is ded, My wele is went, I can no red. But I mot 3et a lytyl stounde Morne for bat depe wounde.

(Manning, Meditations 1533-40)

When Chaucer adapts the amplifying techniques of late medieval devotional writing to a new context in the Man of Law's. 
Tale, however, these ironies operate quite differently. A key example of the perplexing results of such appropriation is Constance's farewell before her second sea-journey. As Weissman has persuasively argued ("Late Gothic Pathos" 150-51), Constance's prayer to the Virgin contains significant echoes of authentic Marian lament:
"Mooder," quod she, "and mayde bright, Marie, Sooth is that thurgh wommanes eggement Mankynde was lorn, and damned ay to dye, For which thy child was on a croys yrent. Thy blisful eyen saw al his torment; Thanne is ther no comparison bitwene Thy wo and any wo man may sustene.
"Thow sawe thy child yslayn bifore thy yen, And yet now lyveth my litel child, parfay! Now, lady bright, to whom alle woful cryen, Thow glorie of wommanhede, thow faire may, Thow haven of refut, bright sterre of day, Rewe on my child, that of thy gentillesse, Rewest on every reweful in distresse.
"O litel child, allas! what is thy gilt, That nevere wroghtest synne as yet, pardee? Why wil thyn harde fader han thee spilt? O mercy, deere constable," quod she, "As lat my litel child dwelle heer with thee; And if thou darst nat saven hym, for blame, So kys hym ones in his fadres name!"

$$
\text { (B) 841-68) }
$$

What strikes many modern readers as problematic in this speech--its self-dramatizing and ceremoniously ornate language--is, as I have argued, a fairly straightforward feature of devotional rhetoric. We should by now be familiar with the strategies of repetition, exclamation, antithesis, and apostrophe with which 
Constance's simple petition--"Rewe on my child"--is heightened and prolonged. Equally clear is the fact that Constance's own identification with the suffering Virgin--an association which, as we have seen, fourteenth-century devotés were characteristically invited to indulge--is in no sense reductive, arrogant, or blasphemous. Neither aspect of the passage should, in light of the traditions it inherits, raise suspicions of irony or satire.

Certain difficulties do arise, however, when we leave aside the scene's dramatic or characterological appropriateness to Constance and instead consider its potential significance for the audience. In this regard the comparison with the Virgin is doubtfully apt. The ostensible point of similarity, of course, is the two women's shared sorrow as helpless victims and compassionate mothers, while its artistic effectiveness lies in the accessible, human quality of the emotion. As we have seen, however, the dignity accorded Mary's grief accrues not on account of the intensity or "naturalness" of maternal suffering per se, but from the Virgin's relation to the unique event of Christian history. Her pain links the viewer to the reality of salvation; it offers an image not of how to mourn one's child, but rather of how the soul should approach the incarnate dying god. This notion stands behind--and to a certain degree makes possible--the analogy in "Nou goth sonne" between Mary and the Bride who 
symbolizes all human longing for the divine presence. The comparison of Constance to the Virgin, however, lacks congruence in both allegorical as well as literal terms:

Thanne is ther no comparison bitwene Thy wo and any wo man may sustene. Thow sawe thy child yslayn bifore thy yen, And yet now lyveth my litel child, parfay!

(B 1 846-9)

Apparently what permits this adaptation of the rhetoric of Marian suffering is nothing more nor less than an outward congruence of distress. Instead of the historical and allegorical parallels prompting Edmund of Pontigny to include "Nou goth sonne" in his Speculum--parallels which form the basis for most medieval thinking about signs and significance--the Man of Law's Tale offers parallels whose significance is experiential rather than doctrinal, overt rather than shadowed forth. It establishes a typology of feeling. Edmund's comparison of Mary to Naomi and the Bride leads the reader to considerations well beyond the mimetic impulses which give works like the speculum their immediate appeal, and implies a whole train of potential extra-textual activities and reflections. The narrator's comparison of Constance to Mary (and, one might add, to Christ elsewhere in the tale) does not, as one expects from a typological parallel, point to some fulfillment beyond itself; indeed, the longer one broods on it, the less intelligible and edifying it becomes. 
The uncertainties that many modern readers feel about the narrator's presence in his tale are closely related, I think, to its refusal to engage with the world beyond the text, to extend its effects forward in time, or to offer any image of how the reader's future might be changed by reading it. In more ideologicallyconceived Christian texts, the motif of virtue-in-distress is ironically juxtaposed with historically- and divinely-ordained ideas of order: the saint can paradoxically triumph in defeat only if the legend successfully invokes a viewpoint transcending the mere appearance of physical disgrace. In the Man of Law's Tale such conflicts appear not in terms of paradox, but rather in the less cerebral form of ambivalence: Constance is tremulous in her faith, and the narrator characteristically invites us to share the moral pleasures of beholding perfect virtue while also indulging in the aesthetic frisson of imagining that virtue injured or defiled. Finally Constance appeals to the audience not because she signifies, but simply because she evokes, and the community of feeling centered upon her pale and suppliant figure is all the more intense and particular for being uncomplicated by ethical and doctrinal concerns. It is perhaps unduly pejorative to describe the tale's orientation as "materialistic" (Wood 151), but we ought in this context to note once again the narrator's recurrent and resolutely ground-level interest in vicissitude, disorder, and 
unpredictability. In accord with this are Chaucer's borrowings from Innocent III's De miseria, a work which, like De consolatione philosophiae, argues from common sense rather than revelation, but which is deeply anti-Boethian in its refusal to transcend material appearances.

In short, whatever the tale's ostensible gestures towards Christian doctrine, its real source of creative energy is the intersection of creatural experience with highly-wrought linguistic artifice. And as we have noted, artifice per se poses certain problems. A good deal has been written about the Christian ideal of plain style, particularly in its relation to the classical tradition (the standard treatment is Auerbach, "Sermo"). In fact, however, a greater stumbling block for moderns is the medieval ideal of high style, in which the author's task becomes the effective ornamental application of the colors of rhetoric. Twentiethcentury responses to the Man of Law as rhetor reveal considerable confusion about Chaucer's likely attitude towards such uses of language. At the heart of our difficulties lies a conviction, probably post-Romantic and all the more powerful for remaining unexamined, which Bernard I. Duffey states succinctly: "A writer cannot strive for sincerity and artificiality at the same time, in the same work, unless his work show far greater complexity than does the Man of Law's Tale. Similarly, it is seldom that artificiali- 
ty and strong emotional appeal lie down together" (Duffey 182).

This sort of equation of plain speaking with moral and artistic sincerity certainly has some currency in the Middle Ages, but with a difference. Ancient theories of decorum assume that style level should be determined not by the speaker's need to express himself, but by the contextual demands of audience and subject matter. Thus high style is reserved for important public matters on which the fates of men and nations depend, while low style is suited to petty matters concerning money, property, and private life. The medieval descendant of this theory, definitively expressed in St. Augustine's De doctrina Christiana, adapts this essentially forensic system of rhetoric to homiletic purposes, and embodies the characteristic Christian delight in the subversion of worldly hierarchy. The incarnation itself, by investing the humblest people and things with the highest possible dignity, has transformed the distinctions on which ancient decorum relies. Low style or sermo humilis becomes exalted almost by virtue of its lowliness, while the high style of antique oratory is correspondingly revealed as empty posturing. Just as the apostles followed Jesus' counsel to give no thought to their own eloquence (Matt. 10:19-20), so the Christian apologist should rely on the fundamental efficacy of Christian revelation, whose sheer historicity can assume the burden of proof--unlike the illusory doctrines 
of pagan philosophy, which are helpless without the support of casuistic feats of language.

Augustine insists that the preacher's best preparation is to attend to his own moral probity. His advice is related to the conviction that the truth is its own best advocate, and insofar as rhetoric is suspect, it should be dismissed not so much because it is pernicious as because it is unnecessary. The Christian author should take the Bible as his model for the right use of ornamental language:

And in those places [in the Bible] where by chance eloquence is recognized by the learned, such things are said that the words with which they are said seem not to have been sought by the speaker but to have been joined to the things spoken about as if spontaneously, like wisdom coming from her house (that is, from the breast of the wise man) followed by eloquence as if she were an inseparable servant who was not called. (Augustine, De doct. IV,vi,10)

Indeed, as this simile of the faithful servant suggests, rhetoric finds dignity not in itself, but in what it serves, a doctrine summed up in Augustine's famous declaration that pagan and secular learning ought to be used rather than enjoyed, like the gold which Israel brought from its captivity in Egrpt lDe doct. ii, $x 1,60)$. St. Augustine and the tradition he so deeply influenced did not, then. distrust rhetoric per se. but rather the untruths and fictions which could not survive without the persuasive force of poetic language. 
The ideal of sermo humilis is an important legitimating force behind narratives like the Second Nun's Tale. The legend's iconic power as a conduit for the divine presence depends on a perfect answerability of word to fact, and on the translator's responsibility for passing on an uncontaminated body of revelation. As we have seen, however, the unquestioned authority of this kind of writing allows, by its very monumentality, the development of a secondary class of texts which gaze into the lacunae of Scripture in hopes of achieving a kind of knowledge beyond the public manifestations of salvation history. The opportunity for achieving meditative knowledge is often a scene of pathos whose secret meaning must be teased out through an intimate exercise of the imagination, and whose key feature is a high degree of rhetorical elaboration. Such writing is distinct from sermo humilis in its ornate treatment of humble matters, yet its effects derive not just from linguistic artifice, but from the same incarnational exaltation which makes the plain style possible.

Within such a conception of sanctified style the Man of Law's. Tale presents a problem because it borrows the rhetorical manner and the artificially circumscribed perspective of the devotional tradition which it formally resembles, but jettisons its fundamental alliance with the ideological underpinnings which are the real source of the tradition's legitimacy. In this regard we may well 
agree with Weissman's claim that "retaining the form of virtue while having lost its substance, Constance performs theatrically instead of performing in fact" (Weissman, "Late Gothic Pathos" 139). We ought, however, to be cautious of her conclusion that the tale is "a deliberate parody of the rhetorized pathos which was the hallmark of Late Gothic devotion" ("Late Gothic Pathos" 139). Certainly the tale's prologue, with its emphasis upon literary decorum and moral probity, alerts us to matters of style and substance; and certainly the pilgrimage-frame creates an ambient irony which is potentially available to each Canterbury tale. But Chaucer's indebtedness to a particular sort of art and literature in the Man of Law's Tale ought, I think, to suggest experimentation rather than satire.

Like the devotional texts we have been considering, the Man of Law's Tale addresses itself to an implied community of readers. But where hagiography reinforces the audience's shared reverence, and where gospel meditation reinforces its fervor, the tale of Constance creates a community out of the very experience of the tale itself: its vicarious emotions and the pleasures they produce constitute a self-reflexive and self-reinforcing activity. Despite its roots in a highly functional literature of piety, the Man of Law's Tale's self-containment suggests a fundamentally different kind of narrative, one that departs from the reinforce- 
ment of cult activities. The tale strives to dignify secular, creatural experience--and to establish a narrative mode for achieving that goal. In this experiment Chaucer moves steadily in the direction of literary "culture"--and in the direction of all that the term "culture" implies about a special readership which enjoys and celebrates its own leisure, refinement, and aesthetic sensibility.

Traditionally the tale has been regarded, in contrast to the "realistic" narratives elsewhere in the Canterbury Tales, as oldfashioned and derivative. Yet the texts and images on which it draws originate in late thirteenth-century Italy and spread northwards--in the case of the visual tradition, via some of the most innovative artists of the period. We might therefore consider that the tale's first audiences found it neither stuffy nor inexpressive, but rather quite daring and avant-garde in its adaptation of a newly fashionable representational style. This hypothesis also leads to the somewhat unexpected conclusion that the Man of Law's Tale may be prime evidence of Chaucer's lifelong interest in adapting Italian narrative materials.

The interpretive difficulties which the Man of Law's Tale has provoked in this century, however, suggest that Chaucer's experiment may have been less than perfectly successful. Certainly the tale's effort to cultivate intense reader responses which yet 
entail no behavioral sequel or moral consequence can seem, especially in light of the overtly functional texts with which the tale is usually compared, insubstantial and trivializing. Yet a different comparison--with the early novel, which also borrowed the form of pre-existing narrative types--suggests how literary innovation must often overcome charges of frivolity and moral vacuity. Chaucer's effort in the Man of Law's Tale to detach the evocative power of narrative from its traditional role as the vehicle of particular doctrines is important, and not just insofar as it anticipates the novelistic conventions for depicting virtue in distress: it also exemplifies the difficulties accompanying Chaucer's effort to articulate a genuinely secular English poetic. 


\begin{abstract}
"NOLITE DARE SANCTUM CANIBUS": SENTIMENT AND FIGURAL STYLE IN THE PRIORESS'S PORTRAIT AND TALE
\end{abstract}

Some years ago E. Talbot Donaldson rather felicitously described the Prioress of the General Prologue as a "woman of style" ("Masculine Narrator"). Though his discussion really addresses the question of Chaucer's literary style rather than of Madame Eglantine's appearance and demeanor, one feels that Donaldson's phrase accurately conveys his sense of the Prioress as a nun who would rather have been a romance heroine. For surely in a romance heroine style is all: her beauty, her deportment, her clothing, her horses and dogs, her books and tapestries all reveal her inner cultivation and grace. A woman of style knows how to select and arrange outward accoutrements in such a way as to manifest her inward, less tangible beauties.

This extra-literary notion of style as a system of selected significances is, I suggest, helpful in thinking not just about the Prioress's portrait, but about her tale as well. The more usual sense of the term--style as rhetoric--scarcely enters into most readers' thinking about the tale, for its actual language is quite 
spare; it makes little use, for instance, of the colores that so dominate the Man of Law's Tale. Only twenty-one of the 202 lines of the tale proper are devoted to authorial apostrophe. The prologue is more syntactically elaborate, but its emphasis on the "labour" ( $B^{2} 1653$ ) of narrating a tale of praise marks the whole as an instance of sermo humilis. Despite its linguistic simplicity, however, one senses an artful quality to the tale's dispositio: its elements seem to be arranged in hopes of striking our sensibilities in a certain way, to be selected so as to engineer our responses. That sort of artfulness, I suggest, is also properly called style, and is related to the more mundane sense of style reflected in the portrait--style as the appropriate selection of accoutrements or furnishings.

Such an argument obviously must take into account the dramatic presence of the Prioress as narrator, and I do indeed hope to offer some statement of how and why Chaucer employs her persona. Most twentieth-century readers of the tale have been preoccupied with the question of whether the complacent and trivial personality depicted in the General Prologue must cast a shadow over the delicate pathos of the tale. They find the Prioress no more trustworthy than the Man of Law. I am myself in no doubt that the ambiguities in the portrait are satirically intended; Chaucer's intentions in the tale, however, seem to me 
less clear. For one thing, the Prioress's presence as a commentator upon her own tale is not particularly strong or insistent. For another, her attitude towards the events she narrates is both perfectly unambiguous and perfectly canonical: it is that mixture of sympathy and reverence still etymologically present in the term "pious," while her simple anti-semitism is, alas, not an idiosyncratic position. The portrait is studded with semantically loaded words like "coy," "semely," "fetisly," and "conscience and tendre herte"; in the tale, on the other hand, we are never in any real confusion over the meaning of such key value-terms as "sely," "cursed," or "pitous."

The reader's problem in the tale is not, then, like the problem in the portrait. The tale's clarity of language and affective directness should render it completely intelligible. Yet many readers persist in feeling, even after considerable efforts to educate themselves about late medieval religious sensibility, that it remains peculiarly inert and opaque. I will argue that this intuition is justified, and that it arises from qualities in the tale that are properly described as stylistic. The tale, like the portrait, confronts us with an artfully arranged collection of things: a great city, a child, an open street, a wicked Jew, a grieving mother, a privy, a grain. These persons and things are presented with a kind of unitary precision, and we ought to note the 
particular care which the Prioress takes to locate them in space and in relation to one another. But despite the tale's mimetic solidity, readers have felt considerable uncertainty about the significance of more than a few of these elements. The privy, for example, seems at one moment to be a symbol of the child's illusory physical defeat, soon to be divinely reversed by his spiritual triumph, at other times to be a fitting manifestation of Jewish carnality and depravity, and at other times to be an indication of what some have viewed as the Prioress's own infantile obsessions. The little clergeon himself seems at one moment to be heroic in his determination to acquire the means of expressing his faith in the virgin, and at another moment to be an emblem of such helpless simplicity that his death cannot, by its pure inadvertence, be understood as a witness to anything but Jewish cruelty. Perhaps the best example is the mysterious grain, which critics have striven to identify--as a pearl, a jewel, or a fragment of the consecrated host--with a lack of success which can only suggest that its meaning is insufficiently determinate. In short, however lucid the Prioress's own words and affections may be, we don't always see how they are intelligibly related to the elements of the tale itself. These things ought to provide a middle term that links the Prioress's intentions with their expression in words; their failure to signify adequately is one way to describe the 
tale's difficulty.

In the modern view, of course, the things in fiction signify because the author makes them do so. Indeed, a chief mark of modern literary artistry is precisely the capacity to devise and communicate private symbolism. One thinks, for instance, of Blake's private mythology, of figures like Wordsworth's solitary reaper, or of objects like Yeats' Japanese sword. Creativity resides in the vision and skill required to make things into images--to make things mean what we want them to mean. The poet's or novelist's authority to confer such significance upon things, persons, and events is not in question; indeed, his very success--the fact of his having communicated his vision--validates the legitimacy of his enterprise. For the medieval poet creativity is rather differently construed. The poet's primary task is not to devise symbols, but to discern and reveal the meaning already inherent in the created universe. Even the fabulator or allegorist constructs his symbol systems in imitation of God's, since, as Alain of Lille's celebrated verse declares, "Omnis mundi creatura / Quasi liber et pictura / Nobis est in speculum" (Rhythmus alter, PL 210:579A). This fundamental distinction in suggested by the difference between the modern poetic term "image" and the theologically-laden medieval term imago.

To ask what things mean in the Prioress's Tale is not 
therefore to ask, as in the Squire's Tale, what cultural context the poet draws on for his system of signification, for the tale's relation to late medieval devotional literature and practices is fairly clear. Instead even the simplest questions about meaning in the tale must lead us into a consideration of how, within medieval terms, things come to bear significance at all. I propose to show that a distinctive feature of the Prioress's Tale is a rejection of traditional medieval kinds of signification, a tendency to dismantle multiple layers of correspondence and to focus on things themselves as if their meaning were sole and self-evident. This tendency, I will argue, is particularly evident in the tale's scenes of pathos, and interestingly anticipates the modern poetic of private creative vision.

I will first discuss how the tale's genre--the miracle of the Virgin--offers an opportunity for such dismantling. Second, I will attempt to define how the elements of the tale ought to be explicable in terms of certain medieval habits of thought concerning signification. In particular I want to analyze the motif of child-murder, its relation to the theological and liturgical symbolism of the Jews, and how it bears on two of the tale's problematic objects, the privy and the grain. My conclusion will be that the tale rejects or occludes, in interesting ways, the culturally established meanings of its various elements. This claim must, of 
course, be tentative. Such an argument is by definition troublesome, for it proceeds not by the usual method of demonstrating the connections between text and context, but by denying the relevance of such connections. I will, however, end with some speculations about why Chaucer should have constructed such a narrative, and why he should have assigned it to the Prioress.

The Prioress's Tale is not a saint's legend, though it belongs to a closely affiliated genre, the miracle of the Virgin. Miracles themselves appear, of course, in a wide variety of narrative contexts: they are, as we have seen in our discussion of the Second Nun's Tale, a key element in hagiography, and they also have, as in the Man of Law's Tale, an important place in more "secular" historical writing. Prodigies manifest the divine will, whether through the instrument of saints and heroes, or as independent signs of God's judgment. In the miracle story per se, however, the narrative tends to shift away from prodigies as evidence of a specific individual's or nation's election, and instead to exploit the marvellous as part of a more generally pastoral argument about divine rewards and punishments as they affect the ordinary Christian. Hagiographic miracles, as we have seen, reinforce the veneration of a special class of persons--the saints--without necessarily offering an ethical model for the faithful. In miracles of the Virgin, by contrast, extraordinary things 
happen to ordinary people, and miraculous instances of reward, punishment, and forgiveness of sins become an instrument of moral suasion. The miracle of the Virgin tends, therefore, to have a more markedly exemplary force: instead of displaying, as in the saint's passio, an unambiguously significant event, it proves a more generalized thesis.

The Prioress's Tale is an interesting case, however, in that the little clergeon is not just the beneficiary of divine grace; in some ways he exhibits the special, elected qualities of the martyr, and his story recalls the authentic saint's passio. The little clergeon is not, as in some of the analogues to the tale, brought back to life; instead the narrative concludes with his death and spiritual translation to heaven. And the Jews, in their foolish wish to assert their own law against the universal truths of Christianity, are a fitting analogue to pagan authority figures of the saint's legend, which are forced, willy-nilly, to testify against themselves. What the tale lacks, however, is the passio's confidence that the miracles of martyrdom display the strength of the martyr's conviction. Saints achieve a principled form of death, chosen in heroic opposition to illegitimate authority. The little clergeon certainly evinces the power of faith, and the miracle of his resurrection certainly demonstrates the Jews' folly in opposing the divine will, but the tale fails to make the necessary 
connection between the two. The child's faith and the Jews'

crime against it are never brought into the conscious collision so central to the drama of the authentic saint's legend.

Interestingly, Chaucer's fictional little clergeon reflects an actual historical category of martyr. Vauchez argues that the late medieval push towards greater papal control of canonization was intended, among other things, to insure that extraordinary virtue as well as miracles and extraordinary suffering became an indispensable element of official sanctity. But at the same time, he notes, the popular veneration of saints often focused on the mode of death rather than holiness of life. In discussing an alarmingly long list of children and adolescents who were believed to have been killed by Jews and who had become, during the period from the twelfth to the sixteenth centuries, the objects of popular cults, Vauchez observes that

deux éléments fondamentaux se retrouvent dans tous ces récits: l'effusion du sang et l'injustice criante que constitue la mise à mort de ces personnages. Comme de nos jours, lorsqu'un condamné apparaît victime d'une grave erreur judiciaire, le spectacle de la souffrance innocente provoquait dans la mentalité populaire un choc profond. Du contraste entre la dureté du châtiment infligé et son caractère inique naissait une émotion, qui, transposée immédiatement sur le registre religieux. s'épanouissait en dévotion. En vertu d'un processus que nous pouvons considérer comme une loi de l'affectivité populaire, la pité suscite la piété. (Vauchez, 178)

The line between piteous death and full-fledged martyrdom 
was therefore often vague. Such a melding of categories appears, for instance, in Caesarius of Heisterbach's Dialogus Miraculorum (1220-35). In the section of the dialogue concerning "simplicity of heart," the monk who is Caesarius' mouthpiece insists on the sanctity of one Margaret of Louvain, a servant who was murdered, along with the rest of her household, by robbers, and who died, so far as the reader can tell, as mere victim rather than as a witness to her faith. He offers the following explanation for the miracles which occurred around her tomb:

Monk: Do you see now how greatly simplicity and innocence of life contribute to the glory of martyrdom? All indeed were slain but all were not distinguished by miracles. From which it is clear that it is not the suffering that makes the martyr but the cause.

Novice: What cause of martyrdom would you say there was in the case of this maiden?

Monk: As I have already said, simplicity and an innocent life. There are different kinds of martyrdom, to wit, innocence as in Abel; uprightness as in the Prophets and John the Baptist; love of the law as in the Maccabees; confession of faith as in the Apostles. For all these different causes the Lamb, i.e. Christ, is said to have been slain since the foundation of the world (Apoc. 13:8). (Caesarius VI, 34 [Vol. I, p. 448])

The novice voices the very question I have raised about

Chaucer's little clergeon, and the monk's reply is interesting in that it seems to redefine martyrdom in purely ethical terms. The classical passio largely takes the saint's virtues for granted; her 
life and death are offered as celebratory recapitulations of principles so clear as to require no explanation--namely the truth of Christianity and the power of God to protect his chosen ones. Caesarius' miracle, by contrast, seems dedicated to the proof of a principle not at all obvious--namely that certain virtues, manifested variously in various individuals, will reap divine reward. The "cause" in this case is not Margaret of Louvain's conscious choice to ally her individual actions with the march of sacred history (presumably her murderers did not seek, like true persecutors, to extirp her virtue) but rather her human striving to achieve, this side of transfiguration, an imitable and ethical perfection. To say that the slaughter of the Lamb is continuously shadowed forth in every instance of struggling virtue is to import into the saeculum the possibility of an ethical martyrdom. It is also to suggest that martyrdom may occur without reporters, witnesses, or persecutors, its true nature becoming apparent only after the fact. It thus becomes, like all things in the material world, subject to degrees of perfection, and subject to misapprehension and overlooking. The monk himself must discern it and persuade the novice of its real existence. Caesarius' example makes sainthood latent rather than overt, and makes our understanding of it a matter of interpretation.

The Prioress's own mention of the child-martyr Hugh of 
Lincoln reinforces the likelihood that the tale employs this more controversial definition of martyrdom and sainthood. This version of sanctity is in a sense parasitic on the classic deaths of the martyrs under Roman persecution; instead of asserting the sacramental identity of all those who perish as they did, instead it poses a shadowy resemblance between their deaths and the deaths of Abel, John the Baptist, the Maccabees, and Margaret of Louvain. Similarly the Prioress's Tale argues for a resemblance between the little clergeon and Hugh of Lincoln. Resemblance is not identity, however, and the very quality of the tale reflects the potential uncertainty of the little clergeon's status.

We might first note that the passio, though rarely "historical" by modern standards, is usually quite specific in its time and locale; this information is an important part of the authentic historical quality of the narrative. The Prioress's Tale is, on the other hand, exceptionally vague in this respect: the characters lack names, the narrator adduces no particular witness as a guarantee of the story's authority, no king or bishop is named to specify the historical time, and the locale is merely a "greet citee" in Asia. Second, and perhaps more important, is the Prioress's treatment of the little clergeon's death. That death is swift and secret--without witnesses and almost without narrative commentary. Unlike hagiographic narrative, the Prioress's Tale 
does not particularly celebrate the child's resistance--whether moral or physical--to injury and humiliation. His miraculous singing does, of course, confute his enemies, but instead of the triumphant impassibility of the classic martyr, the tale emphasizes the child's smallness and physical weakness as a foil for the Prioress's real subject: the Virgin's pity and maternal care.

Thus in its representational style as in its theme the Prioress's Tale departs considerably from the celebratory, institutional nature of the passio. Its miracle serves a more general and anecdotal thesis about every simple believer's relationship to Mary. Just as its story reveals a crime that might, given the busy and callous nature of the wide world, have remained hidden, so the narrator must also reveal the doctrinal message hidden in the elements of her tale. The meaning of the child's death must be drawn out, elucidated, created. We need, therefore, to be concerned not just with the tale's Christian message--whether liturgical, Marian, or polemical--but also with how the narrative and imagery function in conveying that message. This tale, unlike the Second Nun's Tale, takes up the burden of demonstration. Its persons, objects, and events must be shown to bear significance. I have suggested that signification is problematic in the Prioress's Tale, and one possible way to defend that claim is by looking at the construction of the Prioress's General Prologue 
portrait. As I have noted, the portrait is above all a collection of things: the garments, ornaments, pets, and household objects which surround this lady of religious fashion. As U.C. Knoepflmacher has suggested, at least two of the objects mentioned in the portrait possess a Scriptural resonance: the cup which the Prioress takes care to keep free of grease recalls Jesus' warning to the Scribes and Pharisees in Matthew 23:25-6, while the little dogs echo the Canaanite woman's reminder that "the whelps also eat of the crumbs that fall from the table of their masters" (Matt. 15:26-8; Knoepflmacher 180-81). In the first Biblical passage, Jesus uses the Pharisee's cup as an image for an unspiritual attention to outward forms, and this charge has often been levelled against the Prioress herself. The whelps offer an even more complex set of possible associations. The Canaanite women, in comparing her own unworthiness to that of a dog, and the gift of Christ's healing power to the inconsequential act of letting crumbs fall, suggests the value of even apparently trivial works of mercy. One might then say that the Prioress, in feeding her little dogs, enacts the parable literally and perhaps even knowingly. But should we assume that her imitatio Christi also preserves the spirit of Christ's charity? Or is it, as Knoepflmacher argues, "a perversion of the same charity the parable was meant to exemplify" (Knoepflmacher 182)? In both these scripturally- 
inspired details we see the possibility of an action revealing the inward moral nature of the actor.

A particularly interesting case of our difficulties in knowing what to make of the things in the Prioress's portrait arises from the detail of the mouse caught in a trap. As Meyer Schapiro has shown in his analysis of the right wing of the Mérode Altarpiece, which depicts Saint Joseph seated in his workshop and constructing a tiny, elaborate mousetrap, mice and mousetraps carried, from patristic times, a freight of bestiarial and theological meaning. Purely on the basis of their behavior as vermin mice were associated with drunkenness, gluttony, and lust. But they also had an interesting typological meaning in relation to Christ's incarnation and atonement. According to the ransom theory of the atonement, the Son's assumption of human flesh, because it disguised his divine nature, confused and even fooled the Devil, who believed that he was seizing merely another human soul. One key metaphor for this transaction is that of Christ's flesh as the bait on God's fishhook. But another and even more vivid figure, first posed by Augustine, is of Christ's flesh as the bait in a mousetrap, which the Devil, like a mouse, foolishly and eagerly pounces on. Schapiro argues convincingly that the mousetrap is thus particularly appropriate to a painting whose central panel depicts the annunciation--the moment, so to speak, when the trap 
is first set.

One cannot, I think, help but ponder the Prioress's trapped mouse in light of Shapiro's findings. But it is not clear how this typological detail contributes to Chaucer's characterization of Madame Eglantine. Both David H. Brumble III and Stephen P. Witte have suggested that these traditional meanings for the mouse must reflect on the moral character of the Prioress herself. Brumble notes the ironic inappropriateness of her sympathy for this apparently innocuous but actually diabolical creature; Witte argues that the presence of the mouse in the portrait reinforces the Prioress's gluttonous interest in dainty food and drink, while her tears at its entrapment suggest that she is "manipulated, perhaps willingly, in her sentiments and actions by Satan" (Witte 237).

The difficulty with such arguments is not that they rely on a most un-literal appreciation of the mouse itself; Shapiro's own argument, and indeed the entire field of late medieval iconography imply that emblematic objects often evoke a considerable body of highly learned and technical association not always known to all members of the audience, but decidedly present in the artist's or patron's program for the work. The more real difficulty is in seeing how this body of lore is relevant to the characterization of the Prioress herself. We might note, first of 
all, that the mouse is simply not the same kind of symbol as the whelps or the Pharisee's cup. These images, though given a certain privilege by their Scriptural origin, are essentially parables, figures of speech. Their meaning, though based on "natural" qualities of the material world--canine obsequiousness, the daily rituals of cleanliness--arises from an artificially posed equation between things and an ethical state of affairs. They are, in other words, an illustrative and argumentative device; they reflect the intention of their speaker. The speaker in this case is, of course, the incarnate god, but god in human guise, using the contingent and conventional forms of human language. The mouse, on the other hand, signifies not as a word, but as a thing.

As Augustine reminds us in De doctrina Christiana, "a sign is a thing which causes us to think of something beyond the impression the thing itself makes upon the senses" (II.I.2). By this definition the whelps, the cup, and the mouse are all signs. Words and things differ, however, in their manner of signification. Language achieves meaning by a conventional and arbitrary association between words and things. But some things and actions are also signs, and signify intrinsically (whether intentionally or not) according to their created natures. Augustine's examples of this latter sort of signification are the smoke which 
indicates fire, the tracks of an animal which betray its recent passing, or the human facial expressions which manifest a person's inward feelings. The author of such signs is God, and his meaning is expressed not in the changing and conventional medium of language, but in the very substance of the created world.

This signification by things and events is the "language" of types and figures, and if the Prioress's mouse signifies, it does so as a type. The mouse is not in fact the devil; rather its actions recall, in figure, the actual deeds of the fiend. Its characterological appropriateness to the Prioress should depend on a figural likeness between its deeds and hers. We are not, however, told that the Prioress is like a mouse, or that she keeps mice, or that she loves mice, or even that she particularly identifies with mice. If such were the case, we might be well justified in considering the extent to which she exhibits mouselike qualities. But what we are instead told is that she pities its suffering "if it were deed or bledde." Presumably the diabolical and sinful associations of mice are of less importance then the sympathetic bond evoked by its tiny pains.

The issue then is not so much the ambiguities of what a mouse might mean to Chaucer or to any medieval reader, but the fact that the Prioress's reaction to it is precisely none of these; 
instead it is a direct, experiential, and emotional response to a sentient fellow-creature who inhabits a miniature scene of pathos. It is also, of course, faintly ridiculous, and the reader must weigh its valence against the other ambiguous physical signs of the portrait. What I want to emphasize, however, is that the mouse does not cause the Prioress "to think of something beyond the impression the thing itself makes upon the senses." It may well represents a key to the Prioress's moral character, but primarily it reveals what might be called her figural awareness--her capacity for discerning the meaning of things and for bestowing such meaning in the elements of her tale.

A failure to make this sort of distinction between types and the more arbitrary symbols of parable is precisely what enables Sister Madaleva to defend the Prioress's appearance and manner. As she notes, a nun is "a woman whose life has undergone a change more subtle and entirely spiritual than marriage but quite as real" (Madaleva 31), a change caused by two facts: "the first, a mystical but most real relation between the soul and God; the second, the rules and customs and religious practices of the particular community in which the individual seeks to perfect that mystical relation" (Madaleva 32). Religious life, she argues, consists of a decision to express spirituality by bestowing a sanctifying valence on the daily acts and objects of Christian life--by 
making one's life significant in the manner of a parable. Just as the Prioress's tidy garments express her spiritual nicety, so her brooch, her beads, and her dogs must be understood in the symbolically-charged context of religious vocation as style. Thus the question of whether a Benedictine nun should have pets is not exclusively a matter of what the Rule states or how that injunction might be interpreted. Rather it hinges on whether a certain thing and action--a dog and the fact of keeping it--can be made the intentional outward expression of an inward moral reality. Sister Madaleva's analysis the General Prologue portrait is finally unconvincing, however, because she cannot demonstrate that the Prioress possesses any very profound moral awareness which could be so expressed. Her table manners and her little dogs become, by virtue of their parabolic associations, devices whereby Chaucer encourages the reader to make an ethical judgment. The mouse, by virtue of its typological significance, becomes a device to establish her own happy ignorance of the real mechanisms whereby individual motives and universal meanings may coincide. It tells us, in other words, what kind of poet she will be.

Typology arises, of course, from the tradition of Biblical exegesis. As Aquinas notes, the revelation of the intrinsic significance of non-linguistic signs is a key characteristic of Scriptural 
representation:

The author of Holy Scripture is God, in whose power it is to signify His meaning, not by words only (as man can also do), but also by things themselves. So, whereas in every other science things are signified by words, this science has the property that the things signified by the words have themselves also a signification. (Summa Theologica I, Q I, Art 10)

This remark is intended to answer the rather limited question of whether the words of the Bible may be both true and equivocal. Bonaventure, in the Breviloquium, speaks more generally about the relation of Scripture to the world and our knowledge of it:

Now, God speaks not with words alone, but also with deeds, for with Him saying is doing and doing is saying; moreover, all creatures are the effects of God's action, and, as such, point to their cause. Therefore, in Scripture, which is received from God, both words and deeds are meaningful. . . . [Scripture] was given to guide man's thoughts and actions so that he might arrive at his true goal; and since all the rest of creation was designed to serve him in his ascent toward his heavenly home, Scripture takes on the very diversity of created things, to teach us through them that wisdom which leads to eternal life. But we cannot be led to eternal life unless our intellect knows what truths to accept, and our will chooses the good that is to be done, and our heart yearns to see God, and to love Him and to enjoy Him. So the Scriptures, given by the Holy Spirit, take up the book of creation, and adapt it to the final end by a threefold method: by tropology, they teach us how to act as men; by allegory, show us what to believe by faith; by anagogy, reveal to us what to desire for our eternal delight. (Breviloquium Prol. 4:4,5)

This exposition recalls Bonaventure's doctrine of "vestiges" whereby the physical universe offers evidence of God's acts and 
intentions: "For we are so created that the material universe itself is a ladder by which we may ascend to God" (Itinerarium Mentis in Deum 1.2). Examples of this cast of mind could be multiplied almost indefinitely. As M.D. Chenu puts it,

the same men read the Grail story and the homilies of St. Bernard, allegorized Ovid and scrutinized the typological sense of the Bible, or enriched their christological analyses of the sacraments with naturalistic symbols of water, light, eating, marriage. To be sure, they did not confuse either their levels of operation or their objects; but on these different levels they benefited by common recourse to the subtle play of analogies drawn from the mysterious kinship between the physical world and the realm of the sacred. (Chenu 101)

Two points should be emphasized about this "symbolist mentality." First, though the true meanings of things are pluriform and sometimes difficult to discern, they derive their validity from the fact that they are prior to and independent of language. In consequence they are more than mere figures of speech and products of poetic or interpretive ingenuity. Discovered rather than invented, they are translatable, transcending the arbitrary character of individual human languages. Second, and for our purposes more important, they are productive of harmony rather than tension and contradiction. Such ambiguities must be carefully distinguished from the verbal types made famous by william Empson. As Aquinas says,

The multiplicity of these senses does not produce equivocation or any other kind of multiplicity, seeing 
that these sense are not multiplied because one word signifies several things, but because the things signified by the words can be themselves signs of other things. Thus in Holy Scripture no confusion results, for all the senses are founded on one--the literal--from which alone can any argument be drawn, and not from those intended allegorically, as Augustine says. (Summa Theologica I, Q I. Art. 10)

Where literary and verbal ambiguities imply paradox and dissonance, the ambiguity of Scripture's spiritual sense operates additively, enriching meaning through accretion and recapitulation.

The psalms and their commentaries offer a rich practical example of how poetic language can employ the pluriform sense of things. Among the most lyrical of the books of the Bible, and by far the most important in the formation of the liturgy, the Psalter was a key nodus from which early exegetes developed their techniques for teasing out multiple strands of significance. Generally its author was taken to be King David, and the titles prefixed to individual psalms with the compilation of the Vulgate attest to a need to attach these texts to various historical occasions, a tendency given a high medieval revival in Nicholas of Lyra's Postilla litteralis. At the same time, however, all the Psalms were take to refer "in figure" to Christ's incarnation, death, and resurrection, a supposition no doubt based in the perception of the historical David as a type of the historical Jesus.

This figural translation of meaning constantly informs Augustine's Enarrationes in Psalmos. In his commentary on Psalm 
56 (in this case a sermon) he takes note of the context given in the title ("cum fugeret a facie Saul in speluncam" [I Reg. 24:1-4]), but his remarks are predicated on a typological understanding of the Psalms as a whole:

Psalmus enim iste passionem ipsius cantat. Et quoniam totus Christus caput est et corpus, quod bene vos nosse non dubito: caput est ipse Salvator noster, passus sub Pontio Pilato, qui nunc postea quam resurrexit a mortuis, sedet ad dexteram Patris: corpus autem eius est Ecclesia; non ista, aut illa, sed toto orbe diffusa; nec ea quae nunc est in hominibus qui praesentem vitam agunt, sed ad eam pertinentibus etiam his qui fuerunt ante nos, et his qui futuri sunt post nos usque in finem saeculi. Tota enim Ecclesia constans ex omnibus fidelibus, quia fideles omnes membra sunt Christi, habet illud caput positum in coelis quod gubernat corpus suum; etsi separatum est visione, sed annectitur charitate. Quia ergo totus Christus caput est et corpus eius; propterea in omnibus Psalmis sic audiamus voces capitis, ut audiamus et voces corporis. Noluit enim loqui separatim, quia noluit esse separatus, dicens: Ecce ego vobiscum sum usque ad consummationem saeculi (Matt. 28:20). Si nobiscum est, loquitur in nobis, loquitur de nobis, loquitur per nos; quia et nos loquimur in illo: et ideo verum loquimur quia in illo loquimur. Nam quando in nobis et ex nobis loqui voluerimus, in mendacio remanebimus. (Enarratio in Psalmum LVI, PL $36: 661-2)$

As this passage makes clear, at times David's psalms are not merely prophetic of Christ, but in fact become the very words, in propria persona, of the yet-to-be incarnate Christ and his Church, presumably including the later audience for Augustine's own commentary. In interpreting Psalm 4, for instance, he instructs us that "we must look either for the words of the Lord 
Man after the Resurrection, or of man in the Church believing and hoping on him" (Expositions On the Book of Psalms 8, tr. A. Cleveland Coxe).

This kind of plural significance transcends the intentions of any particular speaker or author, and tends, at the furthest extreme, to a convergence of historicities, in which David, Christ, and the devout reader are mystically united in the act of lyrical utterance. The relationship is not, therefore, the purely poetic, memorial, or denotative link between words and things, but the resonance of one act of praise validated and fulfilled by another. This is also, of course, the concept which enables liturgy to function as re-enactment rather than simple commemoration, and the same notion that privileges sacraments over other acts. The words of the psalm thus acquire a significance beyond the merely emotional and connotative; they imply a series of historically congruent actions pointing irreducibly to one another.

One further kind of explication characteristic of Augustine's Enarrationes is particularly relevant to the Prioress's Tale. Though Augustine never loses sight of the text's relation to scriptural history, he devotes a considerable amount of space to exploring the multiple symbolic significances of things. Given the imagistic qualities of the Psalms, this is perhaps not surprising. But just as his assignment of speakers--now to David, now to 
Christ, and now to the devout Christian--tends to focus as much on the act of utterance as on the words themselves, so his procedure in explicating the significance of particular images tends to get beyond mere lexicology and to inquire into the meanings of things themselves. In the sermon on Psalm 56 quoted above, he explicates, among other images, the cave (title), the lions' whelps (v. 4), the spears, arrows and swords of the "sons of men" (v. 4), the net or trap (v. 6), and the harp and psaltery (v. 8). The last of these may serve as an example of his technique:

Exsurge, gloria mea. Ille qui fugerat a facie Saul in speluncam, Exsurge, gloria mea, glorificetur Jesus post passionem. Exsurge, psalterium et cithara. Quid vocat, ut surgat? Duo organa video, corpus autem Christi unum video: una caro resurrexit, et duo organa surrexerunt. Alterum ergo organum psalterium, alterum cithara. Organa dicuntur omnia instrumenta musicorum. Non solum illud organum dicitur, quod grande est, et inflatur follibus; sed quidquid aptatur ad cantilenam, et corporeum est, quo instrumento utitur qui cantat, organum dicitur. . . . Psalterium est organum, quod quidem manibus fertur percutientis, et chordas distentas habet; sed illum locum unde sonum accipiunt chordae, illud concavum lignum quod pendet et tactum resonat, qui concipit aerem, psalterium in superiore parte habet. Cithara autem hoc genus ligni concavum et resonans in inferiore parte habet. Itaque in psalterio chordae sonum desuper accipiunt; in cithara autem chordae sonum ex inferiore parte accipiunt: hoc interest inter psalterium et citharam. Quid ergo duo haec organa nobis figurant? . . . Per carnem suam Dominus duo genera factorum operatus est, miracula et passiones: miracula desuper fuerunt, passiones de inferiore fuerunt. Illa enim quae fecit miracula, divina erant; sed per 
corpus fecit, per carnem fecit. Caro ergo divina operans, psal terium est: caro humana patiens, cithara est. (Enarratio in Psalmo LVI, PL 36:671-2)

It is difficult to tell how serious this argument from the nature of things is intended to be. Perhaps the psaltery and harp are mere object-lessons; but they may equally well be, like the animals of the bestiaries, part of that book of creation which, together with the book of God's word, combines to reveal more fully the divine nature. This latter view certainly should inspire us to take a more sympathetic view of the distinctiones which pepper the later medieval commentaries, and which A.J. Minnis has accused of becoming "a substitute for further thought" (Minnis 68). Here, for example, is Hugh of St. Cher's distinctio on the image of teeth in Psalm 56:4 ("Filii hominum dentes eorum arma, et sagittae"):

Inanis spei. Prov. 25 c. Dens putridus, \& pes lassus, qui sperat super infideli, \&c.

Apertae rapacitatis. Joel $1 \mathrm{~b}$. Dentes eius, ut dentes leonis: \& molares eius, ut catuli leonis.

Occultae detractionis. Mich. 3 b. Haec dicit Dominus super Prophetas,

Dentes qui seducunt populum meum, qui mordent dentibus suis, \&c.

Apertae impugnationis, ut hic.

Venenosae, \& peremptoriae praedicationis. Prov. 30 b. 


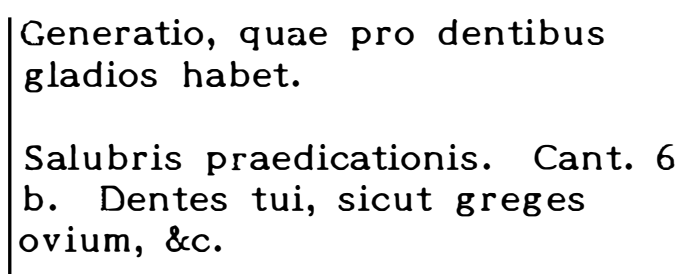

(Hugonis de Sancto Charo, Opera Omnia [Venice, 1732])

Though inspired by a simple verbal concordance, this kind of assemblage depends on a faith not just in the consistency of Scripture, but in the potentially consistent meaning of the thing itself, whether dentes or, as elsewhere in this section of Hugh's commentary, umbra and alae.

The medieval doctrine of signs and signification thus suggests a poetic based on--indeed, enabled by--the intrinsic meanings of the created world. To the author of a miracle of the Virgin it offers the possibility of lending spiritual authenticity to the general, the anecdotal, the stereotypical. History--whether sacred or secular--depends on facticity; reader and author are assured of the potential importance of events by their actuality. The anecdotal miracle, detached from time and place, runs the risk, because it lacks this grounding in circumstance, of dissolving into fable. The doctrine of signs arrests this process, and assures author and reader that even things ungrounded in the historical certainties of time and place may have authenticity of meaning. Because he has instilled meaning into the very sub- 
stance of creation, God makes it possible to discern truth not just in the particulars of history, but in the recurrent, generalized natures of things--not just in this wicked Jew, this murdered child, this miraculous grain, but in the generalized categories of $\underline{a}$ wicked Jew, a murdered child, a miraculous grain. The doctrine of signs ought, in other words, to enable the reader to interpret the Prioress's Tale.

The motif of a child murdered by Jews is of course one of the most striking elements of the Prioress's Tale, both because of its connection with the notorious blood-libel, and because of the bland equanimity with which the narrator presents the wickedness and punishment of her villains. Many critics have tried to deal with the tale's anti-semitism either by attributing ironic or satirical intent to Chaucer (Schoeck; several articles by Rex), or by explaining the tale's attitude to Jews as a regrettable but widespread feature of medieval culture (Wurtele; Frank, "Miracles"; David). The former hypothesis is attractive in that it reinforces our fondness for Chaucer as a proto-liberal, but finally it is unconvincing. As a historical argument it simply ignores the vast evidence that Jews, although entitled as a national group to certain precariously maintained civil rights, occupied a symbolic position in medieval society which was totally incompatible with our own ideals of diversity and religious toleration. Moreover, as 
a literary argument it falls into the trap common to many dramatic readings of the Canterbury Tales: using the appeal to irony as a way of "dissolving" viewpoints repugnant to the modern sensibility.

The attempt to fit the Prioress's Tale into the context of medieval anti-semitism yields, by contrast, a good deal of interesting information about the possible significance of the child and the Jew. Jews in medieval literature often appear, of course, as simple, folklorically-conceived villains. This one-dimensional image, however, represents the shadow of a large and intellectually coherent body of theological lore which literally and symbolically correlates the Jews with the collective enemies of Christendom. Sometimes, as in early Christian apologetics, Jewry represents the aggregate of beliefs and practices which the New Law has come to transform and replace; this conception is concretized in the iconography of Ecclesia and Synagoga. More often in later centuries, however, the Jew is shown as an active antagonist against Christ and his church, and is typologically associated with Satan, Herod, and Antichrist. This aspect of medieval anti-semitism is sometimes described as the "diabolization" of the Jew.

The Prioress's Tale explicitly invokes this complex of types, and in such a context the child must invariably recall Christ and his surrogates, such as Isaac and the Holy Innocents. As Marie 
Padgett Hamilton has shown, many of the scriptural allusions in the Prioress's Prologue and Tale correspond to the liturgical texts for Childermas, the feast of the Holy Innocents celebrated on December 28. One cannot ignore these Biblical associations, of course, or the way that they make the little clergeon's death a type of Christ's sacrifice. The very framework of the tale seems to imply that figural meaning is at work, and that it connects the elements of the tale to larger structures of meaning. In what follows I will explore some of the possibilities suggested by the narrative juxtaposition of the Jews, the child, and the grain.

This juxtaposition occurs through plot, of course, and three plot elements are particularly relevant to how the tale makes its point: ignorance, deception, and surprise. The child's ignorance is obvious; it lends poignance to his Marian devotion, leads to his "foolish wisdom" in singing in the ghetto, and makes him an easy prey for vengeful Jews. The mother's ignorance of her son's fate is an equally important element in the tale's tenderly pathetic tone. The Jews' conspiracy is of course an instance of failed deception. But it is also based on ignorance--of God's power to protect the righteous, to punish evildoers, and to transcend the limits of childish physical nature. This latter ignorance is presented, in complementary fashion to the sanctified ignorance of child and mother, as an ironic instance of the beguiler beguiled. 
These plot elements come together in the tale's concluding surprise: the miraculous singing which confutes the Jews, (apparently) satisfies the grieving mother, and astounds the abbot and his convent.

All miracles are theophanies, and all miracles are in some sense surprising. But the special character of the Prioress's miracle lies in the revelation of divinity in a particularly unexpected place: a song from the privy, a grain beneath the tongue, and Mary's special care granted to the humblest and most unprepossessing of her servants. I suggest that this feature of the tale connects it, perhaps unexpectedly, to two important motifs in religious folklore: the deception of the devil, and the profanation of the host. Both involve the same element of unsuspected holiness, and both, in the way that they lend typological significance to everyday objects, suggest something about the processes of figuration in the Prioress's Tale.

The deception of the devil is a notion derived from early Christian soteriology. It accounts, in essence, for both the humble nature of Christ's human station in life and how his death resulted in the atonement of God and man. As Jeffrey Burton Russell explains it,

Since Satan justly held the human race in prison, God offered himself as ransom for our freedom. The price could be paid only by God. Only God could freely submit. No one else could choose freely, because 
original sin had deprived us all of our freedom. By submitting to Satan's power of his own free will and choice, Christ liberated us from the Devil's power. God handed Jesus over in order to release the hostages. The Devil accepted Jesus. But when he seized him and put him to death, he overstepped the boundaries of justice, since Jesus himself was without sin and could not justly be held. The Devil had held us justly in the past, but when he broke the rules of justice himself, he lost his rights and could no longer hold either Jesus or us. (Russell 82-3)

As Burton observes, this theory not only attributes a certain duplicity to God, but incorporates considerable illogic, "for it hinges upon Satan's ignorance of Christ's sinlessness and divinity. Had Satan really been thus ignorant, he would not have been willing to accept Christ as sufficient payment to begin with" (Russell 140). Though the ransom theory of atonement was largely displaced in formal theology by the sacrifice-theory developed by Anselm in Cur deus homo, it nevertheless persisted in the popular conception as a lively image of Satan, the arch-deceiver, beaten at his own game. As David Wee shows, the notion of Satan's ignorance of Jesus's hidden divinity is a powerful dramatic motif in the Corpus Christi cycles. The marriage of Mary and Joseph, the circumcision of the infant Christ, his suffering during the temptation in the wilderness, and the apocryphal dream of Pilate's wife are all part of a dramatic tension between Satan's greedy desire to seize yet another soul and his suspicions that Jesus is more than he seems to be. The epic scale of the Harrow- 
ing of Hell plays, incorporating as they do the low comedy of diabolic confusion, bring to perfect consummation the popular pleasure in seeing the deceiver deceived, and the beguiler beg uiled.

The ransom-theory is also what underpins Augustine's image of the incarnation as a mousetrap, and Schapiro persuasively shows that the late medieval revival of this idea of the hidden God goes hand in hand with the fashion in the visual arts of cleverly integrating theological and spiritual symbolism into their ever-more-precise renderings of the physical world. The details of devotional genre-scenes (the forerunners of domestic still-life) depict a world which is exquisitely and solidly material and which yet becomes potentially translucent with complex significance. This fascination with the meaning latent in the everyday world is certainly one aspect of the late-medieval devotion to Christ's infancy and childhood: the cult of St. Joseph, newly flourishing in the fourteenth and fifteenth centuries, offers the believer a vivid image of devout humanity entrusted with a secret knowledge of the divinity hidden in its midst.

These historical instances of concealed divinity found, for late medieval Christians, a daily confirmation in the eucharist, in which the Real Presence was cloaked by the accidental appearances of bread and wine. The godhead latent in the consecrated 
wafer is not, of course, strictly speaking an instance of divine trickery. But the effort of faith involved in grasping the mystery of transubstantiation finds dramatic expression in the large number of miracles concerning those who blaspheme against the host, or who approach it without due reverence. Probably the best-known instance of such a miracle is the vision of Pope Gregory's mass. Leah Sinanoglou marshalls a considerable body of such exempla, whose currency she attributes to late medieval veneration of the host. In general they concern an unbeliever whose skepticism is cured by a literal vision of the anthropomorphic Christ whose real presence is ordinarily masked by the appearance of mere bread. By far the most interesting feature of such anecdotes is that the Son manifests himself at such moments not as the adult Man of Sorrows, but as the infant Christ. Sinanoglou attributes this curious fact in part to what might be called the eucharistic nativity, in which the circumstances of Christ's birth foreshadow both the passion and its later reenactment in the sacrifice of the mass. This interpretation appears in a Christmas homily by Gregory the Great:

And he is born in Bethlehem for good reason, since Bethlehem means House of Bread. For He it is who said "I am the living bread which came down from heaven" (Jn. 6:41, 52). Therefore the place where the Lord is born was called beforehand the House of Bread, since it would come to pass that He would appear there in the flesh, who refreshes the minds of the elect with inner satiety. (Homilarium in Evangelia 
Liber Primus, Homilia VIII [PL 76:1104]; quoted and $t r$. Sinanoglou 494).

Such an exegetical tradition explains, according to Sinanoglou, the frequent presence, among the objects littering the foreground of late-medieval nativity paintings, of a sheaf of wheat.

A key subclass of eucharistic exempla concerns the profanation of the host. These stories involve the sudden animation of what the blasphemous protagonist believes to be mere inert bread. The following example, drawn from a fourteenth-century chronicle of Liège by Jean d'Outremeuse, may strve to characterize the type:

In this year [1150], it happened at Cologne that the son of a converted Jew went on Easter day to church, in ordt:r to receive the body of Crod, along with the others; he took it into his mouth and quickly bore it to his house: but when he returned from the church he grew afraid and in his distres's made a hole in the earth and buried the Host within it; but a priest came along, opened the hole, and in it found the shape of a child, which he intended to bear to the church; but there came from the sky a great light, the child was raised out of the priest's hands and borne up to hearen. ("Ly myreur des Histoirs," in Chroniques Belges, Ed. A Borgnet [Brussels, 1864], Vol 4, p. 403; quoted in Poliakov 59)

Here, as in the versions of gospel history influenced by the ransom theory of atonement, a would-be thief and trickster, tempted by the material appearance of incarnate divinity, is himself fooled and surprised by a sudden theophany. Often the victim of such miracles is a Jew, and this fact is hardly remarka- 
ble given the widespread conviction that Jews were irredeemably literal and incapable of grasping the paradoxical mysteries of Christian faith. Their incomprehension was comic, but it was also threatening: as Joshua Trachtenberg notes, in 1267 the Council of Vienna ruled that Jews were required to remain indoors whenever the host was carried through the streets (Trachtenberg 113).

This class of miracle, which, through the symbolic association of the host with the incarnate infant Christ, offers a figure both of hidden divinity and of Satan's deception, poses a suggestive analogue to the Prioress's Tale. It employs the same diabolized figure of the Jew, and makes the sacred presence concrete in the figure of a child. It hinges on the same plot motifs of ignorance: deception, and surprise, and unites them satisfyingly in the motif of the beguiler beguiled. Most intriguing of all is how often the blasphemer attempts to get rid of the host by burying it. Frequently the profanation takes the form, as in the Croxton Play of the Sacrament, of torture and mistreatment which recapitulates the passion, and so perhaps burial is simply the obvious conclusion to such a "murder." It is also possible that the attempted burial in the Prioress's Tale and its analogues is simply the realistic consequence of a literal murder. But the curious typological correspondence between the Christ-child and bread in the profanation anecdotes suggests that certain allegorical levels of mean- 
ing may also be relevant to the Prioress's Tale. Indeed, the notion of the real presence miraculously latent in unprepossessing everyday objects offers, as we have seen in the case of the Mrode altarpiece, a whole procedure for expressing such latent meaning both pictorially and in narrative. It suggests, I proposes, a typological significance for two of the Prioress's Tale's most recalcitrant narrative objects, the privy and the grain. The bread of the host was itself subject to interpretation according to the kind of natural symbolism we saw in our discussion of the Biblical distinctio. As Caesarius points out, the eucharistic elements were given a special status by God's choice of them:

Novice: Can this sacrament be performed in any other grain than corn?

Monk: As the blood can only be made out of wine, and that pressed from the grape, in like manner the body of Christ can only be made out of wheat when it has been made into bread: because the Lord compares Himself to a grain of corn as also to bread. (Caesarius IX, 1 [Vol 2, p. 107])

The text in question is John 12:24, which Gregory the Great uses, in his discussion of the death of King Hermangild of the Visigoths, as a figure of martyrdom. His explanation shows the intersection of the natural symbol of wheat with the symbolic events of salvation history:

We must realize, however, that this work could not have been accomplished if King Hermangild had not 
died for the truth. For, as the Scriptures tell us, "A grain of wheat must fall into the ground and die. or else it remains nothing more than a grain of wheat; but if it dies, then it yields rich fruit" [Jn. 12:24]. This truth, we know. was fulfilled in Christ, our Head. and we continue to see it fulfilled in His members. In the case of the Visigoths. one died that many might have life. One grain died as a faithful witness, and an abundant harvest of souls sprang up to embrace the true faith. (Dialogues 168)

The wheat of the eucharist also suggests the famous metaphor of fruit and chaff. In a sermon for the Easter Vigil Augustine compares this life to a threshing floor, in which the soul's spiritual purification is like the winnowing which strips away the chaff and renders the elect like grains of wheat:

Let him who is in the grain rejoice in the tossing; let him remain; let him not depart from the threshing floor. Let him not. following his own judgment, try to free himself from the chaff, since he will not be able to remain on the threshing floor if he wishes to separate himself from the chaff.

... Therefore hear me, O chaff; yet. if you are listening, you will be chaff no longer. Listen. then. May the patience of God benefit you; may close association with the grain, and may this admonition make you grain also. (Sermons on the Liturgical Seasons 223; pp. 183-4)

As all students of medieval culture know, wheat also represents the spiritual nourishment of Scripture's truth, as opposed to the chaff of mere words. Caesarius recounts what happened to a lazy monk who habitually slept during the Divine Office. One day his companions were granted a vision of him surrounded by pigs, grunting and eating husks. The vision can be interpreted as 
follows:

Husks are empty pods, and they signify the words of the Psalm robbed of all goodness, such as are uttered by the somnolent without any real meaning; and these words, thus half-heartedly spoken, are only thrown out to be picked up by swine, that is, by demons. But they who are fully awake and sing with heart and soul, they who chant the psalms with genuine intention, are fed with all their sweetness, because they reap the grace which lies beneath the prophetic words. Those in the future life, together with the singers of the heavenly Jerusalem, will be fed by the Lord with the flour of wheat (Ps. 147:14), that is, the vision of his Godhead. (IV, 35 [Vol I, p. 232])

This complex of significance which relates the natural qualities of wheat to spiritual nourishment, to the state of grace in this world, and to the fruitful death of martyrs certainly seems relevant to the magical grain of the Prioress's Tale. Sister Madaleva notes that, on entirely intuitive grounds, she has "always taken the greyn laid upon the child's tongue to mean the consecrated Host" (Madaleva 58). Her intuition, it would appear, is justified. Though not explicitly identified as a kernel of wheat, yet the grain's function is similar: it sustains the child, proves his sanctity, and its presence upon his tongue enables him to speak with the perfected eloquence of Psalm 8's babes and sucklings. One further aspect of wheat symbolism is pertinent to the Prioress's Tale, in this case to the child's imprisonment in the privy. The agricultural metaphors of the wheat-and-chaff figure also suggest what can only be called a digestive metaphor, in 
which the wheat is understood in relation to the lowest strata of material existence. As we have seen, the miraculous transforma-tion of the host into a child on the altar reveals the literal reenactment of Christ's sacrifice during the mass. Often such a vision also includes the grisly dismemberment and consumption of the hapless infant (Sinanoglou 492-3). This cannibalistic sequel, the logical consequence of a literalized understanding of the Real Presence, was to become a particular object of Reformation mockery. As Thomas Becon describes it,

A wonderfull God it is, that ye set forth to the people to be worshipped. Not many dayes paste it was corne in the plowe mannes barne, afterwarde the myller grounde it to a meale, then the Baker, myngling a litle water with it, made dough of it, and wyth a payer of whote prynting yrons baked it. Now at the laste come you [the priest], blusteryng and blowing, and with a fewe wordes spoken ouer it, ye charme the bread onsuch sorte, that eyther it trudgeth streygt-wayes awaye be yonde the moone, and a fayre yong childe, aboue xv. hundred yeares olde. come in the place of the bread, or els, as the most part of you papists teach of the litle thynne cake ye make the very same body of Christ that was born of Mary the virgin and dyed for vs vpon the altare of the Crosse, the bread being turned into the naturall fleshe of Christ.

.. And after ye haue made him, ye tear him on peces, ye eate hym, ye digest hym, and send hym downe by a very homely place. ("The Displayeng of the Popysh Masse," 1563; quoted in Sinanoglou 493-4)

This droll and uncharitable interpretation is doubtless an incisive analysis of vulgar faith. What it lacks, however, is any sense of how the incarnation has potentially transformed the: material world 
and bestowed figurative sense upon daily acts and objects. For the unbeliever who regards the host as mere bread, holy communion must similarly entail the shameful imprisonment of God "in a very homely place." As Caesarius suggests, speaking of how heretics and unordained priests are unworthy to approach the sacrament of the altar.

If John [the Baptist] as said S. Augustine had lived in a hermitage from his youth up, and as he was sanctified even in the womb of his mother, did not. dare to touch that tremendous Head of the host so revered by angels, how should you, a polluted sinner. presume not only to touch but as it were to shut up and imprison in a part of your defiled body I do not say the head only, but the whole Christ both God and man? (IX, 53 [Vol 2, p. 158).

His point, presumably, is that the scandal of God chewed, digested, and expelled can only be averted by firm belief in the mystery of communion, which lends spiritual dignity to the basest human processes.

Augustine uses a similar metaphor of transformation in discussing the spiritual utility of sorrow:

Nevertheless, in the time of our misery and, as the Scripture says, in the days of our vanity, we ought to understand the cause of that sadness. For, in a certain way, sadness is like dung. Dung, not con. signed to its proper place, makes a house unclean; but, in its place, it makes a field fertile. . . . But we cannot come to that life of which one does not repent except through penitence for an evil life. Will you, my brethren, as I had begur to say, ever find dung in a sifted mass of wheat? Nevertheless, the wheat arrives at that lustre, at that fine and beautiful appearance. by means of dung. . . A foul period, if 
used to advantage, is a fertile period. What has a more unpleasant odor than a field which has been covered with dung? It was a beautiful field before it received this load of manure; it was first reduced to foulness so that it might come to fertility. Foulness, therefore. is a mark of this time; let that foulness, however, be for us a period of fertility. (Sermons on the Liturgical Seasons 254, pp. 343, 346)

The metaphor of the lustrous grain arising from the ordure of this world must inevitably invite comparison with the little clergeon himself, whose imprisonment in the filthiest lower depths of unsanctified material existence leads to his exaltation among the heavenly hosts who sing a new song before the Lamb. Indeed, one could easily construct a distinctio on all the possibly relevant sense of "grain":

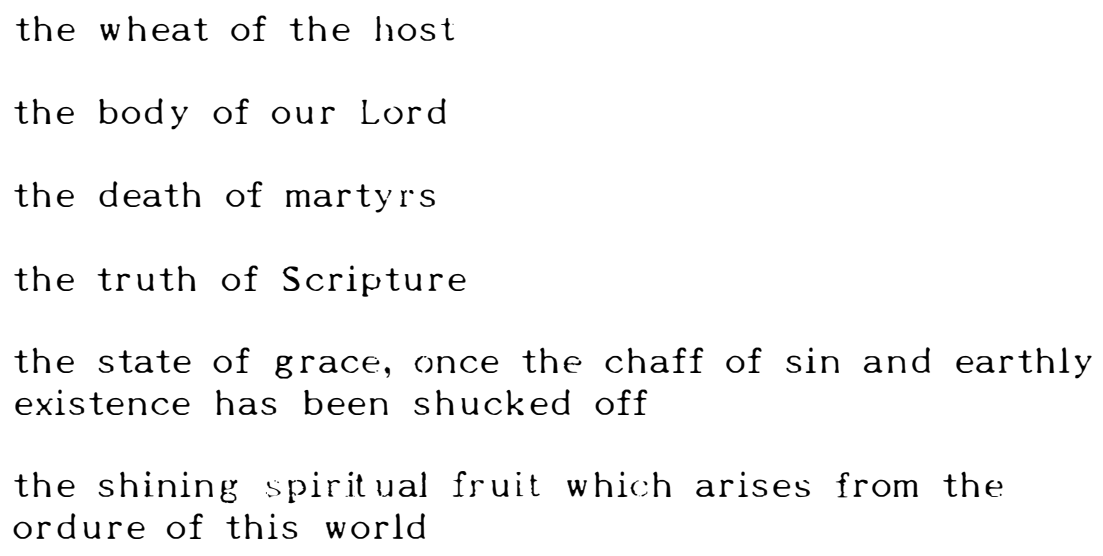

Unfortunately such a distinctio does remarkably little to explain the Prioress's Tale. It would be pleasant to say that just. as in the profanation-miracles the host is transformed into a child, so in the Prioress's Tale the little clergeon becomes a kind of host. The holy power of his pure innocence, invisible to the 
blaspheming Jews, is revealed through the workings of the symbolic grain. He lies quietly, a sacrificial victim, upon the altar during the mass, and the renewal of his singing when he is sprinkled with holy water is a sacramental germination. But the actual operation of the tale's symbolism is less coherent than that. The clergeon does not become like the wheat of consecrated bread, nor does the Virgin's gift of the grain enable him to flourish into the shining fruit of martyrdom. Rather he consumes the grain, temporarily assuming whatever power it embodies, and its removal leads to the final silence of his death.

The stubborn way that the tale seems to neglect its symbolic opportunities is manifested in its treatment of the little clergeon's suffering. The prioress's Tale has, of course, a reputation as one of Chaucer's most extreme "sentimental experiments," but in fact its scenes of pathos are curiously perfunctory. The Jews' wicked plot is detailed in three stanzas of vituperation, while the murder itself receives only the briefest treatment. The very syntax of the lines in which it occurs buries the event in a cluster of clauses describing the murderer rather than the victim:

An homycide therto han they hyred, That in an aleye hadde a privee place; And as the child gan forby for to pace, This cursed Jew hym hente, and heeld hym fast, And kytte his throte. and in a pit him caste. 
The second potential scene of pathos in the tale is the mother's discovery of her child's corpse. It too is prepared for with several stanzas of anticipatory description, this time of the mother's distress: her "face pale of drede and bisy thoght" ( ${ }^{2}$ 1779), her searching "as she were half out of hir mynde" ( $B^{2}$ 1784), her beseeching the Jews "pitously" ( $\left.B^{2} 1790\right)$ for news of her son. Here the actual denouement is a bit more elaborate, but it is still, in comparison to its suspenseful preface, remarkably brief and circumstantial:

This gemme of chastite. this emeraude, And eek of martirdom the ruby bright, Ther he with throte ykorven lay upright, He Alma redemploris gan to synge So loude that al the place gan to rynge. ( ${ }^{2} 1799-1803$ )

The aftermath of the miracle, when the child's singing attracts the attention of the Christian citizens, and of the civil and ecclesiastical authorities, ought to afford the poet his best opportunity to comment upon the meaning of his narrative. The child's long and ceremonious speech ( $B^{2}$ 1839--59), with its matter-of-fact indifference to the horrible fact that his "throte is kut unto [his] nekke boon" ( $B^{2}$ 1839), suggests transfiguration of human nature into an instrument of God's will. But his "explanation" of the miracle is no more than the narrative of what happened in the depths of the privy-Mary's visitation and her gift of the magical grain. Her final words to him no doubt sum up the tale's pasto- 
ral message--"Be nat agast; I wol thee nat forsake" ( $\left.B^{2} 1859\right)-.-$ but that is a conclusion which the reader must draw; neither the child nor his narrator gives it any special emphasis. The responses of the witnesses are similarly oblique: the citizens "wondre upon this thyng" ( $\left.B^{2} 1505\right)$, and carry his body to the abbey "with pitous lamentacioun" ( $\left.R^{2} 1811\right)$; his mother swoons and clings to his bier like a "newe Rachel" ( ${ }^{2}$ 1817); the abbot weeps and "gruf he fil al plat upon the grounde, / And stille he lay as he had ben ybounde" ( $\left.B^{2} 1965-6\right)$. This circumstantial attention to the observers' responses certainly demonstrates the profound character of the tale's miracle, but it does not clarify its meaning.

The Prioress envisions the little clergeon among the virgins "that goon ; Biforn this Lamb and synge a song al newe" ( ${ }^{2}$ 1773-4), but the tale itself simply does not adumbrate this transformation. The child's innocence is the same at the end of the tale as at the beginning, no one is converted as a result of his sacrifice, and the Jews' misapprehension is a failure of human pity, not of spiritual understanding. The grain remains a plot-device which reveals a crime, a magical gadget rather than a mystical symbol.

The way that the grain remains impervious to analysis, lustrously and irreducibly per se. might be taken as emblematic 
of the tale itself: both are exquisitely simple and self-contained objects, alluring, moving, unitary, and only partially intelligible. One might find Prince Hal's words an apt comment on the kind of analysis this chapter has attempted: "O monstrous! but one halfpennyworth of bread to this intolerable deal of sack!" (1 Henry IV II,iv, 514-15). The interpreter's failure to unpack the tale's significance recalls Freud's reported comment, so dismaying to psychoanalysts and literary critics alike, that sometimes a cigar is just a cigar. The same finally goes for the grain, the privy, the child, and even the mouse of the Prologue-portrait. Where the world of the Mrode altarpiece promises to become translucent with meaning, the world of the Prioress's Tale lovingly renders its details completely opaque; its ordered collection of things allows the kind of interpretation we have been attempting to play flickeringly over its surfaces without ever allowing a true illumination.

This view of the tale of course has implications for Chaucer's characterization of the Prioress. Her particular brand of literalism suggests not so much willful obtuseness as a kind of arrested absorption in the immediate, experiential impact of things. Her community of readers, unlike that of the Man of Law's Tale, needs no rhetorical urging to join in the contemplative moment. Their mere humanity is sufficient preparation for 
enjoyment of the tale. The natural, creatural response of all human beings to childhood, to innocence, to murder, and to bereavement are treated as important in and of themselves, as requiring no commentary to justify their narrative interest to the reader.

This fascination with the emotional richness of life's surface textures might properly be called aestheticism, and it extends even to the Prioress's use of Scripture. The Biblical references in the tale, drawn either from the Little Office of the Blessed Virgin or from the mass of the Holy innocents, enter the text not because of the typological multivalence which justifies their presence in the liturgy, but simply because they offer an immediate echo of her own emotional state. Rachel is relevant not as a type of the Church, but quite exclusively as a grieving mother. The Prioress's identification with the babes of Psalm \& completely excludes the traditional interpretalion of these children as those who are not yet perfect in Christian doctrine (see Augustine, Expositions On the Book of P:salms VIII; tr. in Cox, pp. 29--9); she focuses not on God's power to augment their weakness, but almost entirely in their tremulous condition as infantes--that is, as those unable to speak. Her fear that she will fail to translate her devotion into suitable language is in marked contrast to the Second Nun's more confident reliance on a hagiographic tradition 
which can convey meaning without authorial "subtilte."

The issue of translatio is doubly relevant simply because so much of the Prioress's Tale is in fact English translation from the Psalms. As Margaret Deanesly reports, the Psalter was one of the few Biblical books licensed for translation in fifteenth-century England, chiefly for inclusion in the primer and for devotional use by nuns (Deanesly 320, 336ff.). Very probably women religious in Chaucer's England would have known their psalms primarily in vernacular versions. That fact is interesting because a recurrent anti-Lollard fear was that Bible translations would, by freeing the reader of the schooling and interpretive apparatus which had traditionally been part of the study of the Latin text, reduce Scripture to mere letter. Proponents of the English Bible, by contrast, emphasized the immedialely accessible and revelatory quality of Scripture, as in this sermon attributed to Wycliffe:

As the high priests set thit: stone at the door of Christ's sepulchre, so our high priests dread... that God's law should quicken after this, and therefore they make statutes, stable as a stone, and get grant of knights to confirm them .. . lest that truth of God's law, his in the sepulchre, burst out to knowing of the common people." (Wycliffe, Selected English Works. I.129: quoted in Deanesly 399)

Chaucer's Prioress presents a moving example of this point of controversy: her response to Scripture is full, intense, and literal. Her Bible, like her brooch, serves as an artful ornament 
to devotional life. We, of course, perceive this aspect of her character more clearly that she does. One rallying cry among opponents of the English Bible was nolite dare sanctum canibus: give not that which is holy to dogs. This remark, drawn from Jesus's sermon on the mount (Matt. 7:6), also appears in his conversation with the Cananite woman (Matt. 15:26-8), and acquires a troubling inflection when we recall the Prioress's own little dogs. In this context they suggest her inability to draw anything but literal, carnal nourishment from the bread of Scripture, just as she seems blind to the typological resonance in her sorrow for a trapped mouse, her sympathy for the little clergeon's mother, or her identification with the innocence of a child. The kind of reification and disabling of traditional signifi-cance that we have found in the Prioress's Tale has implications beyond any ironic characterization of the Prioress herself. One might say that the dramatic portrayal of her spiritual limitations as a nun paradoxically widens Chaucer's horizons as the ultimate author of the lale: it allows him lo experiment with literal narrative. When Schapiro characterizes the meticulousily naturalistic technique of the Merode altarpiece as a foreshadowing of a fully secularized mode of represtntation, he might as well be describing Chaucer's own literary innovation:

The devoted rendering of the objects of the home and the vocation foretells the disengagement of still lifr. 
as a fully secular sphere of the intimate and the manipulable. Religious thought tries to appropriate all this for itself; it seeks to stamp the freshly discov-ered world with its own categories, to spiritualize it and incorporate within it a scheme of other-worldly values. . . On the other side, the enlarged scope of individual vision makes this art increasingly a vehicle: of personal life and herice of subconscious demands. which are projected on the newly admitted realm of objects in a vaguely symbolic and innocent man-. ner. . . . The new art thus appears as a latent battlefield for the religious conceptions, the new secular values, and the underground wishes of men, who have: become more aware of themselves and of nature. (Schapiro 9-10)

Ut pictura poesis: such a secularization seems at work, albeit. fugitively, in the Prioress's Talt. Chaucer's adoption of the ironically-compromised Prioress as his mouthpiece may, of course, simply mean that he condemns the sensibility from which the narrative emerges. It may also mean, however, that he needed the implied context of her sort of limited religiosity simply to contain the tale and to make its procedures intelligible. 
"THIS TALE IS SEYD FOR THIS CONCLUSIOUN--":

PATHOS AND EXEMPLARY FORM IN

THE LEGEND OF GOOD WOMEN

This chapter moves from Chaucer's treatment of devotional and sacred subject-matter to the classicizing and secular narratives of the Legend of Good Women. In these texts Chaucer no longer focuses on public, wonder-working sufferers. Instead he enters the realm of private, secret anguish. His protagonists, lit by mortal affections rather than by the theophanic blaze of supernatural power, display human rather than divine nature. Their sufferings are psychic rather than physical: the literal deaths with which their tales end are merely the conclusive manifestation of a previous psychological agon.

In describing the Legend as "secular" I am not employing the usual modern reference to ideas and activities divorced from spiritual concerns, for clearly Chaucer's suffering ladies sustain injuries to their souls as well as to their reputations. By "secular" I mean simply the whole category of ideas and activities, many of them true and important, which fall outside the magic and timeless circle of the sacred; they lack the sanctifying touch, whether scriptural, liturgical, or mystical, of divine authority. 
The paganism of the good women is one clue to their confinement within the saeculum, and Chaucer's narrative method is in accord with the world they inhabit.

The classical materials in these texts are, in some sense, historical, but they lack the iconic status of sacred history. They are, in other words, available for major reinterpretation. Chaucer's sources for the Legend, whenever they are known to us, seem to have offered him starting points for his real literary work of alteration, amplification, abbreviation, and re-arrangement. By far the most frequent form of authorial commentary in these texts is the occupatio, in which the narrator defines major portions of his sources as unimportant to his real task. This sense of the author's prerogative to choose and to alter is, of course, central to the narrative mode which I have called the exemplary. If these stories mean quite differently from their sources, it is because the poet has made them do so.

The framework for these texts is classical history, but in each of them Chaucer uses the larger political conception of Athens or Rome as a background for a story-within-the story. Such a sense of close-up is not, of course, unique to these tales; the Prioress achieves a similar tight focus on the little clergeon, whose frailty and obscurity in the midst of a busy, great city make him easy prey for his enemies. But unlike the little cler- 
geon, the protagonists of the Legend do not reveal their moral importance through a sudden public miracle. Instead their sufferings remain hidden, waiting to become known through the commemorative medium of poetry.

These texts engage, in other words, the reader's wish to penetrate the surface of the "official" story, and to know what truths may arise from the private and the unregarded. Pathos inevitably engages the personal, but in these texts the radically individual nature of suffering is, within the world of the story, unmediated by witnesses who might articulate a public norm of response. For the most part the sole spectators to the scenes of pathos in the Legend are the narrator and the reader; no observer within the world of the legend itself offers a narrative image of our possible responses. The protagonist displays herself through the private, idiosyncratic language of the planctus, and the interpretation of her experience is left up to the intimate, readerly community of the author and his audience.

The quite radical re-interpretation and recontextualization which Chaucer practices in these texts is one cause for the puzzlement with which modern readers have sometimes regarded them. In comparison with Troilus and the Canterbury Tales, the Legend of Good Women has provoked little sustained commentary; it is no less interesting than those texts, however, in the way it 
gives us trouble knowing whether its various stories mean what the narrator says they mean, and whether we can take its narrative persona at face value. In this century there has been little consensus about whether the collection is seriously intended as a classicizing adaptation of the traditional hagiographic form (Lowes), or whether it constitutes some kind of parody (Goddard; Garrett). Even among those who incline to the latter view there is little agreement about what the object of that parody might be--anti-feminism, the sentimental love tradition, hagiography, or even didactic narrative itself. The Troilus of course poses similar notorious problems. Though no reader, so far as I know, has suggested that the poem is parodic in any systematic way, arguments about the kind and degree of irony present in Chaucer's narrative voice have dominated modern Troilus-criticism.

I should state at the outset that once again, as in my analysis of the Man of Law's Tale, I initially mean to sidestep the whole matter of parody and irony in the Legend. No one seriously believes, of course, that the women of the Legend are actually martyrs, and the Prologue's gentle comedy must preclude our reading the ensuing tales in too solemn a light. Yet I cannot agree, for instance, with readers like Pat Trefzger Overbeck, who argues that the actual nature of the "good woman"'s behavior--- 
her rashness, passion, irrationality, and indifference to legitimately instituted authorities--fatally undercuts the narrator's tone of blanket commendation. On the whole the tone of the legends themselves seems to me relatively straightforward in its sympathetic presentation of female suffering, and I would suggest that the critic's task is to account for that directness. One of my goals in this chapter will be to argue that the women of the Legend do indeed evince a literary form of "goodness" which transcends their moral doubtfulness, and that this "goodness" is related to their availability for depiction in scenes of pathos.

This is not to say, however, that the Legend does not present the reader with certain very peculiar and sustained discrepancies between matter and form. One important reason to entertain the theory of Chaucer's parodic intent is the overwhelm-. ing sameness of his presentation. The attempt to fit Cleopatra and Thisbe into the same mold is bound to cause discomfort, and I would suggest that the problem of tone in the Legends is directly related to the reader's own observation that the collection is simultaneously too homogeneous and too varied. In other words, we cannot help but notice that these ladies, individually "good" though they may be, are not good in the uniform fashion claimed by the collection's form and narrative commentary. That claim to uniformity is, of course, reminiscent of hagi- 
ography, in which the lives of the saints all meld into a single pattern of holiness and of divine instrumentality. But the women of the Legend are not saints, and in this chapter I want to disengage the Legend of Good Women from the idea of hagiography and consider it instead in light of that large and various body of medieval narrative usually known as the exemplum. This approach has the advantage of explaining, as I hope to show, a good deal about the form and style of the Legend. I have already argued that while the Second Nun's, Man of Law's, and Prioress's Tales are best understood with reference to the cultural notion of the icon, the Legend of Good Women represents an exemplary mode of narrative. In this chapter I will explore the degree to which the Legend does not just exhibit exemplary tendencies, but actually embodies the medieval genre of exemplum itself. It does so, I will argue, in ways interestingly related to the pathetic: Chaucer experiments with the possibility of lending literary dignity to the representation of secular experience, and he does so by rendering each legend an exemplary scene of pathos.

The exemplum is, of course, a didactic anecdote. This concise definition of authorial intent, however, does little to illuminate the form and inward workings of a genre so familiar to students of medieval literature. As Bremond, LeGoff, and Schmitt 
have analyzed it, the medieval exemplum includes the following formidable list of characteristics: 1) narrativity, 2) brevity, 3) veracity and explicit claims to authority, 4) a tendency to occur in subordination to some larger textual structure, and 5) a homiletic, pedagogical, and persuasive orientation (Bremond et al. 367). Finally and most interestingly, they suggest that the exemplum is fundamentally anagogical in its appeal to the ultimate goals of human activity: it is "dominé par le souci des fins. dernières de l'homme. C'est, si on nous permet l'expression, un gadget eschatologique" (Bremond et al. 37; see also the similar definition in Berlioz; the survey of modern criticism of the exemplum in Kemmler; and the analysis of the ancient and medieval fable in Powell). These characteristics appear in a wide range of medieval discourse--from the beast-fable to the parable to the miracle to the moralized lives of famous men--and can describe anecdotal material occurring in a bewildering array of contexts, from sermons to encyclopedias to the newly-emerging late medieval story-collections best represented by the Decameron. What is distinctive about the form, however, is its juxtaposition of the narrative with the ideological: the exemplum combines the mimetic and dilatory pleasures of fiction--suspense, irony, surprise--with the determinate and discursive focus of ethical and philosophical analysis. Unrolling itself in the temporal dimension of story, it 
achieves not just closure, but actual point.

A good exemplum must, of course, possess the graceful proportions of all good narrative, but its didactic intent requires above all that it be not just pleasing, but also effective. Subject-matter here is less important than presentation, and the literary techniques by which the exemplum achieves efficacy are its most salient generic characteristics. On the most obvious level, the exemplum tends to arrive dressed in authenticating details of time and place: the narrator has read the story in a particular place, or heard it from a first-hand informant; he locates it in a specific city in the time of a named and wellknown ruler. More fundamental, however, is the efficacy produced by brevity and selection. As Paul Zumthor puts it, the "récit bref" must possess

unité de l'événement narré, quelle que puisse être la complexité de ses causes ou de ses effets; les unes et les autres possèdent du reste, le plus souvent, une sorte d'evidence interne éliminant toute ambiguïté de surface. Cette structure se manifeste généralement en ceci que l'aboutissement de l'action constitue une "pointe": je veux dire une cause finale par laquelle est produit et en vertu de laquelle s'organise ce qui précède et l'amène--toutes proportions gardées, comme dans l'epigramme; il en résulte, pour le lecteur ou l'auditeur percevant, selon la linearité du récit, les unités successives de celui-ci, une forte impression de compacité temporelle et spatiale, limitant beaucoup--sinon éliminant--l'imprévisibilité des actions et des circonstances. (Zumthor 7-8)

One consequence of this structural principle, he notes, is that "le 
déroulement de l'action tend ainsi à se retourner sur lui-même. La conclusion épuise les prémisses" (Zumthor 8).

"Limitant," "éliminant," "épuisant"--Zumthor's terms here reveal a good deal about the modern reader's view of didactic narrative. The presumed tidiness of the exemplum--its tendentiousness, its determinate significance, and its closure--is often unattractive to the modern reader. We chafe at what Susan Suleiman describes as the "hybrid character" of the roman à thèse: a "tension between two opposing tendencies: the simplifying and schematizing tendency of the thesis, and the complicating and pluralizing tendency of novelistic writing broadly conceived" (Suleiman 201). Unlike that forerunner of modern fiction, the novella, the exemplum seems to disregard the mimetic principle we desire in narrative, and, as Hans-Jörg Neuschäfer notes, to restrict its focus artificially: "puisque, en effet, la narration élimine volontairement tout ce qui ne s'intègre pas à la morale, il ne peut pas venir à l'idée du lecteur que les choses auraient pu prendre une autre tournure" (Neuschäfer 105).

Even critics who regard the exemplary mode with sympathetic interest tend to emphasize its rigidity and determinacy. In a very suggestive argument about the "decline" of high medieval exempla into merely entertaining stories like the novella and the fabliau, Frederic C. Tubach characterizes the pure form (the 
"proto-exemplum") as a triumph of doctrine over representation:

Tangible phenomena are employed only as symbols of man's acceptance or rejection of the ethical precepts which lead to harmony with the divine order. . . . Social environment has no significance and the world of phenomena represents only a stark stage on which God confronts man. The norm against which human behavior is weighed and judged is absolute and therefore not subject to change. (Tubach 411)

In these terms the development of late medieval narrative represents a movement from simplicity to complication, from certainty to ambiguity, and from programmatic stylization to a narrative mode more "like life itself":

C'est précisement cette réflexion a posteri ori sur les événements et non pas les événe ments eux-mêmes, comme dans l'exemplum, qui revêt une fonction essentielle dans la nou velle. En d'autres termes, tandis que dans l'exemplum, l'événement même était définitif, qu'il contenait déjà un jugement irrécusable sur l'ordre des choses qu'il créait, la nou velle ne croit plus que l'événement en lui- même contienne déjà un sens transcendant. Perdant ainsi son irrécusabilité et son car actère de démonstration didactique, l'événement devient problématique et contesté. (Neuschäfer 107)

Insofar as Chaucer's legends seem to privilege private, individual experience in conflict with "un jugement irrécusable sur l'ordre des choses," one is, of course, tempted to say that they are proto-novelle rather than exempla. And indeed, one notable strain in Legend of Good Women criticism argues that they demonstrate Chaucer's own rejection of the notion that "l'événement en lui-même contienne déjà un sens transcendant." 
The collection's thesis never quite succeeds in controlling its narrative particulars, with the paradoxical effect that the legends themselves are quite astoundingly unpersuasive: no one comes away from them convinced, as the God of Love seems to be, that true women and false men are the norm. Lisa Kiser concludes from this fact that one important object of Chaucer's satire is the very idea of exemplarity itself, personified in the God of Love's crude aesthetic:

For writers like Chaucer, who experimented with literature's potential to express philosophical subtleties, irony, and the complexities of life, the widespread presence of heavily moralized exempla must have had serious consequences. First, readers must have become accustomed to seeing moralization, clearly defined characters, and obvious "goods" and "evils" in literature. Furthermore, not finding such things spelled out by an author, readers might have felt encouraged to supply them on their own. (Kiser 79-80; see also Mehl 137 on didacticism; and the similar remarks on exemplary catalogues in McMillan 26)

Kiser argues that the choice of classical materials freed Chaucer from the clumsy constraints of Christian moralizing and supplied "a variety of stories about love, all of them rich and complicated treatments of a universal human experience under the 'law of kynde' that 'was and is and ever shall be'" (Kiser 70).

This appeal to "richness" and "complexity"--to the true poet's presumed thirst to reproduce "real life"--underlies Robert W. Frank's reading of the Legend as an experiment in "pure 
story." The sentimentalism of the legends is an important component of this experiment; it permits

a more comprehensive kind of statement than is possible in the pure exemplum, since feeling is at once more complex and more ambiguous than moralization, which normally oversimplifies an action and narrowly limits the range of reaction. An audience can only accept or, less customarily, reject a moral. Feeling, however, does not disengage us from the human actions which created it, and it evokes reactions from a wider and subtler range of human experience. (Frank, C. and the LGW, 174)

Certain notions in this line of argument--notably the assumption that complexity and ambiguity are aesthetically and philosophically preferable to simplicity and closure--are, I think, seriously open to dispute. Indeed, as we have seen in our examination of the Man of Law's and Prioress's Tales, close attention to the complexities of individual feeling may actually work against the achievement of significant "universal" vision. Even more open to question is the assumption that the exemplum offers the poet an easy, pre-packaged solution to the problem of narrative signification. My own analysis suggests that the author of an exemplum seldom arrives at disambiguation and narrative determinacy with quite the mechanical neatness that students of didactic literature have claimed. Indeed, we need to consider the degree to which the oddities of the Legend of Good Women arise from the very nature of Chaucer's assigned task as an exemplarist. 
Of course there really is no such thing as a paradigmatic exemplum--the form is simply too various--but the following three non-Chaucerian texts can help us isolate some of the practical difficulties in attaining the genre's presumed "irrécusabilité et . . caractère de démonstration didactique" (Neuschäfer 107).

The first is from an English translation, probably made in the fifteenth century, of the Gesta Romanorum:

Caclides was a wys emperoure regnyng in the cite of Rome; in be Empire of whom ther were two knyghtis, oon was oold, and pat opir was yong. the old man had weddid to wif a yong damysell, and the yong knyght had weddid an old woman; and both thes men duellid in oo cite, ny to-gidr. So hit happid in a certein day, that this yong knyght had a grete y $3 e$ on the yong wif, that was yweddid to the old knyght, and was hily ravisshed in to hir love; and pought "bat hit had be more conuenient me to haue had this yonge woman, and pe oper man my wif." And in dede he spak to this yong woman, \& she grauntid him; but she was kept, bat she myght not breke oute, to do no trespas. So pis woman lokid oute oft tyme at her chamber wyndowe, for to here the swete song that the yong knyght vsid to syng; and afore this wyndow stode a feire fygge-tre, vpon be whiche a nyghtingale vsid to sit \& syng; and therefore be yong lady vsid ofte tyme to rise in the nyght to here this brid syng. At pe last the old man, her husbond, perceyved hit, and seid to hir, "Telle me the cause whi bou risest so ofte fro thi bed." "A! ser," quod she," pere is sittyng in the tre suche a brid, pat syngeth swetly, and I arise to here him." \& be knyght arose $\mathrm{vp}$, and toke an arowe and a bowe, and shet at pe brid, \& slowe hit; \& drowe his hert oute, \& caste hit to her, \& seid, "Take pere the hert of him, for whos song bou ros vp so anyght fro me. And berfore fro hennys forward hold thi bed." When pe yong knyght herd telle how that he had slawe this brid, he thought, "if he knew how moche I 
love his wif, he wold do to me as he hath do to pe brid; but hit shal not be so." He armyd him, and entrid in to the hous of the old knyght, and slow him; \& sone after his old wif died, and bo he weddid the yong wif.

Moralite. Dere frendis, this Emperoure is oure lord Ihesu Crist, Fader of heven. In his empire beth two knyghtes,--how so? pe yong knyght was moyses, pat weddid the old wif, scil. pe old lawe, pat was byfore the natiuite of Crist: the old knyght is our lord Ihesu Crist, the which is withoute begynnyng; and he weddid a yong wif, when he made the new lawe, \& fylid not pat othir, as is seid in the gospell, Non veni soluere legem, sed adimplere, I come not to lose or vndo be lawe, but to fulfille hit. but moyses \& all othir profitz and patriarkes desired for to se this new lawe of Crist, and to be weddid perwith; but pei myght not se hit. The lady ros vp ofte tyme for to here the swete song of the bird; by the lady we vndirstond pe soule, made to be likkeness of god, pe which owith to arise fro the bedde of synne, and here pe song of pe word of god, and of holy scripture. The fyg-tre, pat stondith afore pe wyndow, is pe Cros of Crist, pat stondith afore oure y $3 \mathrm{en}$ : the brid, pat syngeth so swetly, is the manhode of Crist, pe whiche praied his fader for vs on the cros; and pere in pat tre was slayn by men for oure synnes. And perfore we shuld wed his wif, scil. his lawe, \& lede perwith pesable lyf, and haue euerlastyng lyf. (Gesta Romanorum 60-62)

What first strikes us about this exemplum, of course, is the oddity of the moralitas. Presumably the allegory is enabled by a very general congruence between Christian doctrine and the love story: that an ostensibly tragic act of violence leads unexpectedly to a long-hoped-for outcome. The similitude is reinforced by the analogies between the tree and the cross, the marriage bed and the life of sin, the bird's song and the sweet words of Scripture. The comparison is also, however, quite muddled in respect 
to other elements in the story. I am myself disconcerted to find the old knight, whose jealousy is in keeping with the rigidity of the Old Testament god, identified with Christ. The marriage of old man and young wife symbolizes the new law of the Christian dispensation, but the marriage bed which makes that union manifest, and to which the old knight/Christ recalls his wife/the soul, is in the moralitas explained as "the bede of synne." The young knight's murder of his rival is not explained at all; indeed, the author treats it as irrelevant to the central allegory of the soul's marriage to Christ as a "pesable lyf." In order for the exemplum to work, the author must ignore large chunks of the story itself, and must also ignore most of the judgments we might make about such events as they appear in "real life" rather than parable.

The Gesta Romanorum are noted for their far-fetched moralitates, and one might simply say that the peculiarities of this exemplum are wholly the product of the author's allegorical zeal. More "normal" (that is, more literal) versions of this story appear in Marie de France's Laüstic and in the fourth tale of the fifth day of the Decameron; both are more accessible in that they seem to employ a more familiar, quotidian model of human motives and relationships. Yet the very differences in their treatments suggest how many possible turns the story could take, from Marie's sentimental portrait of love brutalized by the actualities 
of woman's captive estate, to Boccaccio's genial comedy of young lovers overcoming the obstacles to their union. The central narrative element--a young woman who explains her nocturnal love-longing in terms of her desire to hear the nightingale sing--acquires particular significance only in a larger context of narrative intent. It can, on other words, be made to mean various things.

It is interesting, therefore, to note that the compiler of the Gesta has in fact exercised considerable care in his attempt to frame a narrative which will support the moralitas. He omits, for instance, any expansion of or moral commentary on the anecdote's initial situation, thereby forestalling potential problems of sympathy or satire directed towards the old husband and the young lovers. He is similarly brief in his account of the murder which resolves the plot difficulties. The central events, however, fully elaborated with dialogue and narrative detail, are the young wife's nocturnal lingering at the window, and the crucial episode of her husband's jealous response. This relative expansion encourages both our identification with her yearning, and also our own distress at her husband's attempt to restore her marital fidelity by slaughtering the bird. In terms of the moralitas these choices are quite precise and appropriate: the wife's love-longing is revealed as the natural and morally commendable desire of the 
soul for God, while her husband's deed (which perhaps seems less contemptuous and angry when we reread it in an allegorical light) suggests that the incarnate sacrifice of Christ's human nature, apparently a tragedy of suffering, can actually lead the soul to fuller union with those aspects of God which are "withoute begynnyng." Indeed, the old knight's words to his wife employ a central Christian devotional image: "Take pere the hert of him, for whos song bou ros vp so anyght fro me." The fit between story and interpretation here is not, I think altogether convincing, but there is clear evidence that whatever efficacy the exemplum achieves is, to a large degree, the result of authorial craft. When we juxtapose it with Marie's and Boccaccio's versions we see that the "story itself"--"les événements eux-mêmes"--may resist certain burdens of meaning, but also that it can have no intelligible existence apart from a particular author's treatment.

One might, of course, say that this fragment of the Gesta Romanorum is anomalous. Most medieval exampla are less driven by anagogy, and it is certainly true that my second example is on the face of it less peculiar. Drawn from the Disciplina clericalis. of Petrus Alfonsi, it appears to be a straightforward tidbit of pragmatic counsel:

Another man gave the following advice to his son: 
"My son, work for the world to come[,] before death snatches you from work." Another said, "Take care that the joys of this world do not deceive you, and that you be not ensnared by the falsities of the world, lest you forget that death is to come, and lest there happen to you what happened to the thief who entered the house of a rich man." The son then asked: "Tell me, father, what happened." And the father began the story. A thief entered the house of a rich man and found it full of treasures. He was so beside himself, that he took from all the different piles more and more[,] and something from the piles that was yet more precious. Anything of lesser value he left, but spent so much time in choosing that day broke, and found him still deciding what to do. The guards[,] who had wakened without his noticing, found the thief still choosing. They seized him, beat him with staves and thongs, and threw him into a deep dungeon. Eventually sentence was given on him, as for anyone who has made a confession, and he had to listen and face the sentence of death. Now if this man had thought at the right moment of how near dawn was, he would never have been beaten with thongs and sticks, nor, what is worse, would he have been made a head shorter. (Disciplina clericalis. 158; added punctuation is mine)

This exemplum seems to be a natural and obvious illustration of the proverbial wisdom that he who hesitates is sometimes lost: the nearness of death should encourage us to decide, as the thief cannot, what is worthwhile in life. It would appear that this exemplum, in contrast to the previous text, achieves considerable surface coherence between the moral and the narrative. But I would argue that even this apparently simple exemplum entails interesting problems of signification. Once again the author has chosen a key moment in his story for rhetorical expansion: the thief "was so beside himself, that he took from all the different 
piles more and more[,] and something from the piles that was yet more precious." This brief but vivid point of entry into the protagonist's state of mind serves to dramatize and reify the error against which the exemplum warns. Distracted by beauty and pleasure, the thief forgets the ineluctable progression of night towards dawn, and of life towards death. The moral meaning seems to flow seamlessly from the natural symbolism of night and day. Yet one can, given medieval habits of thought, easily imagine an alternative moralitas, perhaps like that of Henryson's "Cock and the Jasp": the rich man's treasures betoken the spiritual gifts of the kingdom of heaven, gifts so enthralling that the contemplative soul, in the person of the thief, is willing to transgress secular authority and even to suffer death for the pleasures of earthly communion with heavenly riches.

In both these exempla, then, the overt moral seems potentially compromised by extra-textual forces: in the Gesta Romanorum the moralitas incompletely suppresses the psychological and ethical responses which readers necessarily import from their own daily experience of such situations, while in Petrus' exemplum the prudential, "real life" implications of the event are potentially contradicted by the traditional anagogical meanings of such elements as the rich man, his treasures, and the approaching dawn. In short, this pair of texts calls into question certain key 
assumptions about medieval exampla: that they are by definition simplistic in their style and narrative construction, that they repress the author's creative impulses, and that the genre is enabled chiefly by the rigid and schematic nature of medieval allegorization, rather than by authorial skill.

My third text is from Boccaccio's De claris mulieribus, and it differs considerably from the first two. For one thing, it appears in a collection whose aims are as much scholarly as moral. For another, it clearly participates in the humanist project of antiquarian and commemorative writing. Boccaccio's compilation thus reflects his own judgments about which ladies deserve a niche in the House of Fame, and their claritas is at least as much a consequence of his having chosen to memorialize them as it is a criterion for their selection in the first place. Yet the actual text--the life of Hippo--exhibits characteristics which link it to my earlier examples:

Hippo was a Greek woman, as is clearly shown in the books of the ancients. I will hardly believe that she was great because of only one excellent deed, for we rise to lofty things gradually, and therefore no one becomes great suddenly. But since through the malignity of time knowledge of her family, her country, and other things done by her has perished, I thought that I would manifest the one deed of hers which has come down to us, so that it will not perish and the honor due her will not be taken away.

Well then, we are told that Hippo happened to be captured by enemy sailors. She was a beautiful 
woman, and, hearing those who had seized her make plans against her and against her honor, she valued the purity of chastity so highly that, since she could not safeguard it except through death, she did not wait for violence but threw herself headlong into the sea, where she lost her life but saved her honor. Who will not praise so firm a decision on the part of a woman? For at the cost of the few years with which she could perhaps have prolonged her life, she saved her chastity, and with her premature death she gained eternal honor for herself. The tempestuous sea could not keep hidden her virtuous deed, nor could the deserted shore prevent the perpetual testimony of literature from preserving it to her honor in the eyes of men. After being mockingly tossed by the waves for a while, her body was hurled onto the Erythraean shore, where the inhabitants of that country buried it like that of one who had been shipwrecked. But finally, when words spoken by her enemies disclosed her identity and the reason for her death, the Erythraeans with deep reverence built a great, long-lasting tomb on the shore where she had been buried, as a memorial to her chastity, so that we might know that virtue's splendor cannot be obscured by any adversity of Fortune. (Boccaccio, De claris mulieribus, LI)

The point of this exemplum is twofold: first, it praises Hippo's chastity and resolve, both of which the author takes to be worthy of imitation; second, and by far more important, it holds up the discovery of her noble death as evidence that "virtue's splendor cannot be obscured by any adversity of fortune." The central reflection on the philosophy of history is reinforced, as in the exempla we have already examined, by a rhetorical elaboration which marks its significance and intensifies its emotional effect. After giving us the relatively matter-of-fact information that Hippo "threw herself headlong into the sea," 
Boccaccio devotes his full lyric powers to the fate not of her body, but of her reputation: "The tempestuous sea could not keep hidden her virtuous deed, nor could the deserted shore prevent the perpetual testimony of literature from preserving it to her honor in the eyes of men."

In general De claris mulieribus seems to follow a more comfortably modern program of moral interpretation, driven less by the author's need to make a particular point than by the implications of the available information. Boccaccio's stance as historian first and moralist second seems familiar and commonsensical. In Neuschäfer's terms, he begins not so much with "l'ordre des choses qu'il créait" as with "l'événement lui-même." Yet it is in fact instructive to consider how slenderly the narrated facts of Hippo's life support the significance which the author claims for them. We cannot know, for instance, what was her real motive for suicide: Boccaccio adduces her virtue, but offers no testimony in support of that conclusion; the facts he narrates might just as well have been the result of terror and despair. Likewise her obscure death and later fame might, to a different interpreter, suggest the unpredictable and cruel ironies of Fortune, who seldom bestows honor where and when it is due. In short, while the life of Hippo ostensibly draws its moralitas from the objectively-considered events of history itself, actually Boccaccio's exem- 
plary narrative relies (as his reference to "the perpetual testimony of literature" reveals) almost entirely on a rhetorical tour de force of skillful syntax, inventive imagery, and the judicious invocation of philosophical commonplace. Hippo's claritas is an artifact, and the artifex is Boccaccio himself.

These three texts--allegorical, practical, and philosophical in their respective moralizations--are all of course very different, and if nothing else demonstrate the variety of the exemplum as a genre. What is worth emphasizing, however, is the fairly high degree of effort they exhibit in their collective task of pummeling and extracting meaning from narrated events. This, I would argue, is a crucial characteristic of the medieval exemplum. All three of the texts we have examined depend on the author's certainty that particular narratives can be demonstrably related to ideas outside and beyond the text. That is a certainty they share with the sacred genres which we observed in previous chapters. To note this fact, however, is merely to observe that exempla, saints' lives, miracles, and devotional meditations are all the products of a single cultural matrix. Bremond, LeGoff, and Schmitt's apt designation of the exemplum as a "gadget" (37) suggests the way it differs from other medieval genres. A gadget is an ingenious human artifact, and so is the exemplum. And as the term "gadget" implies, the exemplum inhabits the 
realm of human rather than godly agency. It expresses its author's skill at clothing an idea in appropriate surface garb, and its prime literary expression is the fable, in which a single moral truth may be couched in a potentially infinite variety of integumenta--some perhaps more pleasing or fitting than others, but all suffering the equivalent handicap of fictiveness. Platonic myths, Ovidian metamorphoses, and the epic Reynard cycles are, despite their surface distinctions, equivalent instances of the beautiful lie.

Such a conclusion is at odds with the modern notion that hagiography and miracle-stories are essentially fantastic, sensational, and ahistorical, while the moral truths of faithfully observed typical human experience have self-evident dignity and pedagogic value. But we might entertain the possibility that for medieval audiences quite the reverse was true: the hagiographer enjoys the authority of sacramental tradition, and relies on the audience's reverent eagerness to draw closer, by means of the legend's iconic power, to the sources of God's presence in the world. The historian, like the symbolist author of a bestiary or psalm commentary, derives authority from his readers' conviction that God's intentions reside hidden in the world of things and actions. The exemplarist, by contrast, undertakes the much more difficult task of persuasion. He cannot claim to reveal the true 
meaning of this historically-situated husband and wife, or of this thief; nor can he claim to reveal the latent and supra-circumstantial significance of husbands, wives, and thieves themselves. Instead he must convince his reader that particular elements of his particular narrative may profitably be understood in a particular way.

His position is secular, and its consequences are manifold. The truths he offers require not just exhibition, but demonstration, since every exemplum may, as we have seen, potentially give rise to a subversive counter-exemplum. The ad hoc quality we observed in the exempla from the Gesta Romanorum, from Petrus Alfonsi, and from Boccaccio is as much the result of the limits of the genre as of the oft-cited medieval propensity for finding farfetched significances everywhere. Dealing with materials which must, in medieval terms, be invented rather than translated, undertaking a labor of proof rather than of commemoration and celebration, the exemplarist must actually make meaning. Even as he strives to articulate ultimate principles, still his position is radically empirical and rhetorical: rhetorical because he operates in the realm of opinion and argument, and empirical because the truths he conveys are both pragmatic and contingent.

The medieval exemplum is thus a familiar, domesticated, and useful genre whose actual function yet remains deeply problemat- 
ic; and I would argue that its built-in tensions find direct expression the Legend of Good Women. However illuminating it may be to consider the Legend in light of hagiographical traditions, still what fundamentally defines it is its exemplarity. Genre itself ushers Chaucer's project, with its ostensible wish to communicate absolute ideas, into the contested arena of rhetoric and opinion. The unpersuasive character of the Legend has led many modern readers to suspect the presence of irony or satire. We ought, therefore, to inquire more closely into how the peculiarities in the poem arise from the simple fact of exemplarity itself, and which emerge from the particular use he has made of his chosen form. As a preliminary one might note that the individual legends themselves fit all of Bremond, LeGoff, and Schmitt's criteria for exemplarity: they are self-contained narratives subsumed within a larger structure, they repeatedly make the customary appeals to authority and veracity ("And this is storyal sooth, it is no fable" [Cleopatra, 702]), and they at least pretend to a pedagogical and homiletic intent. The criterion of brevity is perhaps more difficult to claim, since actually several of the individual Legends are quite as lengthy as a good number of the Canterbury Tales. At the same time, however, they evince the exemplum's typical compaction, selecting only the relevant details and omitting all others: 
But of his aventures in the se

Nis nat to purpos for to speke of here... (Dido, 953-4)

I coude folwe, word for word, Virgile, But it wolde lasten al to longe while.

(Dido, 1002-3)

Wel can Ovyde hire letter in vers endyte, Which were as now to long for me to wryte. (Medea, 1678-9)

Of this Lucresse, that starf at Rome toun[,] And in what wise, I wol but shortly trete, And of this thyng I touche but the grete. (Lucrece, 1691-3)

The remenaunt is no charge for to telle...

But, for I am agroted herebyforn (Philomela, 2383)

To wryte of hem that ben in love forsworn, And ek to haste me in my legende (Which to performe God me grace sende), Therfore I passe shortly in this wyse. (Phyllis, 2454-8)

And shortly, lest this tale be to long ... (Hypermnestra, 2675)

We have also seen that the effective exemplum requires a certain limitation of its vision, a narrowing, often achieved rhetorically, of the story's implications so as to exclude ideas and responses which might undermine the moralitas. Chaucer's tinkering with his sources would seem to be of precisely this sort, as when he excludes the good woman's crimes (e.g., Medea, Procne and Philomela), or when he suppresses any circumstances which might mitigate the wicked man's betrayal (e.g., Dido). Champions of heavy irony in the Legends often point to this kind of manipulation as evidence for satire. Certainly the notion of Cleopatra as Antony's helpless victim is irreducibly risible, and I do not want 
to underestimate its comic effect. At the same time, however, I must emphasize the degree to which the exemplum-form requires the reader to entertain just such altered emphases as part of the genre's very artificiality. Though the exemplarist regularly claims accountability to his sources, in fact, as we have seen, the task of rhetorical proof inevitably leads him to just the distortions of emphasis that the Legends exhibit. Chaucer's jugglings may represent an extreme case, but they are not in themselves atypical: the subtexts implied by what we already know about the good women are, in a way, no more than the counter-exempla always latent in the form.

I have already suggested that the exemplarist's task is burdensomely empirical, and this observation helps us to place the usual charge associated with the unconvincingness of the Legends--namely that their claim about female virtue and male wickedness is untenable. This objection has to be weighed against the proof-value of exempla in general. Although the exemplarist can amass instances which support the likelihood of his thesis, no mere accumulation, not even of "an hundred on a rewe" (Prol. LGW, G285), can permit him to reason from individual cases to a fully valid universal principle. Even the secular rules of logic dictate that the premise "some women are victims" cannot yield the conclusion that all women are. The exemplarist's lack of 
the only kind of authority that counts finally prevents him from arriving at the certainties enjoyed by hagiographers and exegetes. Chaucer's legendary exposes this aspect of the exemplum in an exaggerated and witty fashion: no number of instances can offset the perfidy of a Criseyde, or alter our certain knowledge that counter-exempla exist.

The Prologue to the Legend of Good Women raises this very issue, as well as others relevant to the exemplarist's task. As Robert O Payne has argued so well in The Key of Remembrance, the Prologue is in fact a complex discussion of the ars poetica. Payne's analysis emphasizes the poet's need to balance the competing claims of experience and literary authority--of real daisies and of their poetic metamorphosis into figures like Alceste. My own sense of the Prologue is that its discussion is a good deal more specific: it deals with the difficulties of making sense both of daily experience, and also of the literature that arises from such daily experience. It is, in short, an examination of the secular poet's position in a secular world.

The Prologue opens with the famous lines relating literary authority to religious faith: "Goddes forbode but that men sholde leve / Wel more thyng than men han seyn with ye!" (Prol LGW G10-11). The narrator's list of "olde aproved storyes / Of holynesse, of regnes, of victoryes, / Of love, of hate, of othere 
sondry thynges" (G21-23) suggests considerable initial confidence in books as a repository of truth. He himself is merely a gleaner after the authors who have already "lad awey the corn" (G62), and writes chiefly to honor their earlier endeavors:

But wherfore that I spak, to yeve credence To bokes olde and don hem reverence, Is for men shulde autoritees beleve, There as there lyth non other assay by preve. $($ G81-84)

Lines like these suggest an authorial persona who is secure with his own humble position in a great tradition; the familiar image of wheat and chaff allies poetry comfortably to scripture and to philosophy.

Intruding into this dignified version of the poet's vocation, however, is a slightly different, more nervous voice. It first appears as part of the narrator's reflections on his own inability to praise the daisy aright:

For wel I wot that folk han here-beforn Of makyng ropen, and lad awey the corm; [And] I com after, glenynge here and there, And am ful glad if I may find an ere Of any goodly word that they han left. And if it happe me rehersen eft

That they han in here freshe songes said, I hope that they wole nat ben evele apayd, Sith it is seyd in fortheryng and honour Of hem that eyther serven lef or flour. For trusteth wel, I ne have nat undertake As of the lef agayn the flour to make, $\mathrm{Ne}$ of the flour to make ageyn the lef, No more than of the corn agen the shef; For, as to me, is lefer non, ne lother. 
I am witholde yit with never nother;

I not who serveth lef ne who the flour.

That nys nothyng the entente of my labour.

(G61-80)

This passage apparently links the narrator's general reflections on poetry and poetic authority to a specific example of the sort of tradition that ought to be respected. That example--the debate about the flower and the leaf--is not, perhaps, the exalted subject the reader expects. Nor does the reader expect the narrator to prove his humble attitude to authority by avowing his own scrupulous indifference: "For, as to me, is lefer non, ne lother. / I am witholde yit with never nother" (G75-6). Most surprising of all is his nervous protestation that he would no more champion leaf against flower--or flower against leaf--than he would prefer corn to sheaves (G71-74). I suppose his remark might simply mean that one can no more separate the flower from the leaf than one can separate wheat from the stalks upon which it grows. But the appropriation of this less-than-random example is telling, since the traditional function of authority is precisely the separation of intellectual wheat from the stalks and chaff in which it may grow, but which interfere with its final purpose as spiritual nourishment. The image of poetry in this passage is not quite, therefore, the exalted enterprise to which the narrator elsewhere refers. Instead it is a realm of trifling controversies in which the newcomer had better be careful not to embroil 
himself.

The God of Love might well serve as both the symbol and the mouthpiece for this vision of poetry. He makes a stunning appearance ("aungellych" [G168]), but his actual words reveal the trivial basis of his authority. His power is that of rank rather than virtue, and his appearance within a dream-vision as a "god" comments ironically on the limitations of fable. His charges of "heresy," like his comments on poetry, reveal, in slightly different form, the problems inherent in the passage on the flower and the leaf. He accuses the narrator of disloyal service, and would like to pretend that the wayward poet's responsibilities were perfectly clear:

Why noldest thow as wel [han] seyd goodnesse Of wemen, as thow hast seyd wikednesse? Was there no good matere in thy mynde, $\mathrm{Ne}$ in alle thy bokes ne coudest thow nat fynde Som story of wemen that were goode and trewe? Yis, God wot, sixty bokes olde and newe Hast thow thyself, alle ful of storyes grete, That bothe Romayns and ek Grekes trete Of sundry wemen, which lyf that they ladde, And evere an hundred goode ageyn oon badde.

This knoweth God, and alle clerkes eke That usen swich materes for to seke.... Ek al the world of autors maystow here, Cristene and hethene, trete of swich matere; It nedeth nat al day thus for to endite. But yit, I seye, what eyleth the to wryte The draf of storyes, and forgete the corn? (G268-79, 308-12)

The God of Love would like to claim that the difference 
between literary corn and chaff is obvious, and that the narrator's failure to observe it is mere obstinacy. His description of the poet's task, however, reveals a model of composition in which the dominant image is not winnowing, but rather the ransacking of literary tradition for scraps in which to dress one's own opinion. Certain key words and phrases in this passage are especially revealing: the "world of autors" is wide and various; other clerks "usen" it to "seke" out evidence, and it hardly takes them "al day thus for to endite"; the narrator must be either a dunce or a heretic to be unable to "fynde / Som story of wemen that were goode and trewe"--doesn't he have a copy of "Jerome agayns Jovynian," or of the Epistola Valerii ad Rufinum (G280281)? The "corn" of stories is, of course, what flatters the God of Love and encourages others to serve him, and there is, finally, no way for the hapless dreamer to refute this view of secular poetry as a particularly shameless form of propaganda.

The narrator mildly observes that representing false love is not the same as endorsing it, and feebly protests that "it was myn entente / To forthere trouthe in love and it cheryce" (G4612 ), but these hermeneutical niceties seem to make little impression upon either Alceste or the God. Alceste's excuses for the poet are also curiously divorced from any claim that the poet is a gleaner of truth: perhaps someone has slandered Chaucer, or 
perhaps, since "he useth bokes for to make, / And taketh non hed of what matere he take" (G342-3), he wrote Troilus and the Romaunt of the Rose mechanically, in ignorance of their full implications, or perhaps he wrote to please a patron. Her manner is dignified and gracious, but it is decidedly secular. Her worldly explanations, manifestly drawn from the very undreamlike experience of the court poet, are in marked contrast to the divinelysanctioned poetic motives to which the narrator alludes at the beginning of the Prologue, and which so explicitly accompany the Second Nun's and Prioress's Tales. The Prologue thus defines not merely the task of the Legend, but also the contested literary arena in which it is to take place. Exemplary narrative is, in the droll but also rather demeaning terms of the God of Love, the appropriate selection and disposition of materials designed to bolster a thesis. The poet's job is not to inquire into the truth of that thesis, but to amass instances sufficient to silence and outweigh dissent.

The Prologue thus suggests that Chaucer is well aware of what sort of enterprise an exemplum collection can be, and that he is capable of mischievously deconstructing some of the limitations of the genre. Whether the Prologue's parody of aesthetics and literary patronage actually expresses Chaucer's own dismissal of the exemplary mode is, I think, a question to be approached 
with caution. What remains to be addressed is the degree to which the legends themselves carry out a discernible exemplary program.

The greatest problem with the notion that the Legend is a parody of exemplarity itself, is the reader's uncertainty about just what proposition the collection is meant to assert. Alceste defines the poet's ideological task as if it were simple and obvious:

Thow shalt, whil that thow livest, yer by yere, The moste partye of thy tyme spende In makynge of a gloryous legende of goode women, maydenes and wyves, That were trewe in lovynge al here lyves; And telle of false men that hem betrayen, And al here lyf ne don nat but assayen How many wemen thay may don a shame. (G471-78)

What, however, defines the "goodness" and "truth" that she specifies? Not, presumably, that the good woman is an imitable model of civic, religious, or moral virtue--all possibilities precluded by the disruptive and tragic nature of her experience. As the recent spate of interesting feminist criticism on the Legends shows (Ames, Delany, Overbeck; see McMillan 4-5 and 49-51 for a survey), there is certainly reason to think that Chaucer was quite interested in the "good" woman's inability to reconcile her highly individualized view of passionate love with the institutionalized demands of patriarchy. But while this form of conflict 
runs throughout the collection, it does not rise to the level of an explicit unifying principle. Nor, presumably, does the Legend support the claim that the good woman's love is somehow a pagan version of sacred violence, for Chaucer quite carefully suppresses both the ritual mayhem committed by some of his heroines, and also the Ovidian metamorphoses that might lend a certain spiritual transcendence to his love-tormented characters. Nor, finally does the collection prove the blanket assertion of male wickedness that prompts Goddard to exclaim that "a more exact, if less ironical, title for the poem would be The Legend of Bad Men" (Goddard 59). Indeed, the notorious unconvincingness of the Legend seems closely related to the fact that the reader comes away uncertain of what, if anything, she was supposed to be persuaded of. The notion of the Legend as straightforward parody seems considerably undercut by our inability to discern just what proposition Chaucer is mocking.

My own consideration of form in the Legend suggests that Chaucer is interested in narrative experimentation rather than mockery. His reworking of his sources is an exercise in the kind of selection, omission, and heightening that can, through purely literary means, alter the meaning of a story. And formally speaking that exercise exhibits quite precise intentions. What really ties together this flock of ladies so otherwise different in their 
ages, estates, lovers, and kinds of misfortune is not, in fact, moral or thematic. Rather it is Chaucer's own construction of each legend such that its heroine becomes the focus of a formal scene of pathos. The good women's availability for contemplation as pathetic sufferers for love is the "goodness" that unites them, and we should note that it is good both in the God of Love's quasi-moral terms and in the representational opportunities it affords the poet. Any reader of the legends must note how Chaucer abbreviates the complexities of background story in favor of amplified tableaux of victimization, and how often the narrative speeds relentlessly not towards the heroine's death, but towards the moment of ultimate, fragile isolation in which she offers her conclusive utterance:

And next the shryne a pit thanne doth she grave, And alle the serpentes that she myghte have, She putte hem in that grave, and thus she seyde: ...

(Cleopatra 680)

Tysbe ryst up withouten noyse or bost, And saw hire wympel and his empty shethe, And ek his swerd that hym hath don to dethe. Thanne spak she thus: ...

(Thisbe 887-90)

But as myn auctor seith, yit thus she seyde; Or she was hurt, byforen or she deyde, She wrot a lettre anon that thus began: . . . (Dido 1352-4)

A lettre sent she to hym, certeyn, Which were to longe to wryten and to sen, And him reprevith of his grete untrouthe, 
And preyeth him on hire to have som routhe. And of his children two she seyde him thus: ... (Hypsipyle 1564-8)

And therfore in hire letter thus she seyde Fyrst, whan she of his falsnesse hym upbreyde: . . . (Medea 1670-71)

Adoun she feyl aswoune upon a stone; And up she rist, and kyssed, in al hire care, The steppes of his fet ther he hath fare, And to hire bed ryght thus she speketh tho: . . .

(Ariadne 2207-10)

Hire letter was ryght long and therto large. But here and ther in rym I have it layd, Ther as me thoughte that she wel hath sayd. She sayd,...

(Phyllis. 2515-8)

The focus in the Legend is not on the heroine's moral qualities as a true lover, or even on how she has been victimized; it is on victimization itself as a state of being--and of speaking. As Donald Rowe observes, paraphrasing Dido, "here the swans immolate themselves that they may sing" (Rowe 138).

Readers have long suspected that the real subject of the Legend is poetic rather than amatory, and much recent criticism has emphasized (rightly, I think) the relation between the legends proper and the Prologue's discussion of authority, tradition, and the poet's craft (Frank, C. and the LGW; Kiser; Rowe). But such readings have not dealt well with the presence of highly rhetoricized pathos in the Legend. Readers looking for satire, of course, regard the florid character of the good woman's lament as 
a swipe at the God of Love's sentimental aggrandizement of erotic concerns over all others. Those concerned with source-study worry about how such lyricism simply aggravates the Legend's willful obfuscation of all the moral, political, and doctrinal issues contained in the works from which Chaucer drew. Those who enjoy the moments of pathos in the Legend have, on the whole, been forced to justify their preference with historically inadequate arguments about the superiority of feeling to morality.

I would propose that the lyric moments in the Legends--the planctus or pathetically-treated description with which nearly every legend ends--are of particular technical interest to Chaucer, and that he is able to exploit them largely as a consequence of the peculiarly rhetorical nature of exemplary writing. We saw earlier that even in much simpler and clearer exempla than the legends, the author often reinforces his moralitas through narrative detail and linguistic ornament. In part this method is simply one way to signal the relative significance of some portion of the text. At the same time, however, it reinforces the text's intellectual aims: the reader's interpretive attention is heightened by the enticements of a powerful surge of language. In other words, certain parts of the text initially become more significant because we experience them as more significant. I would suggest that however lightly Chaucer may have taken the Legend as an intel- 
lectual exercise, he took this rhetorical aspect of the exemplum--at least from a technical standpoint--with absolute seriousness. The consequence is a narrative whose moralitas seems, at key moments, to become inseparable from the reader's own experience of verbal texture. This theory of pathos in the Legend of Good Women is not, perhaps, susceptible to historical verification, but it does have the advantage of exploiting a more historically accurate view of exemplary narrative, and of avoiding the doubtful and anachronistic assumption that literary feeling and ambiguity are somehow more "real" than morality and closure. My claim, therefore, is that secular pathos is one of the central stylistic and structural principles of the Legend, and that it interests Chaucer because it offers opportunities for experiment in "makyng." Yet that term, which so dominates the Prologue, implies both the author's freedom to select, recombine, condense, and dilate, and also his confinement within the secular realm of creatural experience and imperfect cognition. It is a form of writing that both expands a horizon and limits the poet's vision to what can be seen from the ground. V.A. Kolve, in his analysis of how the Legend of Cleopatra establishes the world of the legends which follow, has spoken eloquently of this sense of philosophical confinement:

Cleopatra's death-scene, in which the asps of historical tradition become the mordant worms of the grave, 
is paradigmatic: it expresses the naked truth those other destinies bear at their center. Chaucer displays the "good women" of his poem as locked in a mortal coil in which dust embraces dust, whether in the marriage bed, through rape, or in a descent into the grave. Within such limits a poet can "make of sentement" [make verses about feelings] only ( $F$ 69), for the suffering that is Chaucer's present subject redeems nothing and is redeemed by nothing: it yields emotion, not meaning. (Kolve, "Cleopatra to Alceste" 151)

The single clear exception to this pattern is Lucrece, whose legend falls in the precise center of the collection (the fifth of nine), and who has, significantly, no major final speech. The pathos of her disgrace reveals itself in not in lament but in action, a suicide which reveals, even in its final gesture, the principles according to which she has lived:

Al hadde folkes hertes ben of stones, Hyt myght have maked them upon hir rewe, Hir herte was so wyfly and so trewe. She sayde that, for hir gilt ne for hir blame, Hir husbonde shulde nat have the foule name, That wolde she nat suffre by no wey. And they answerden alle, upon hir fey, That they forgave yt hyr, for yt was ryght; It was no gilt, it lay not in hir myght; And seyden hir ensamples many oon. But al for noght; for thus she seyde anoon: "Be as be may," quod she, "of forgyvyng, I wol not have noo forgyft for nothing." But pryvely she kaughte forth a knyf, And therwithal she rafte hirself hir lyf; And as she fel adoun, she kaste hir loke, And of hir clothes yet she hede tok. For in hir fallynge yet she had a care, Lest that hir fet or suche thyng lay bare; So wel she loved clennesse and eke trouthe. 
The brevity of this passage, its emphasis on action rather than speech, and its incorporation of witnesses to the crucial moment mark it as qualitatively different from the other legends.

Chaucer's own commentary is also distinctive, for he notes that "nat only ... these payens hire comende, / But he that cleped is in oure legende / The grete Austyn hath grete compassioun / Of this Lucresse" (1688-91), and that the memory of "hir chaste blood" (1862) led Brutus to banish Tarquin and establish the Roman republic; because of her deed "she was holden there / A seynt, and ever hir day yhalwed dere / As in hir lawe" (1870-72). These remarks suggest that Lucrece's "goodness," unlike that of the other good women, is noteworthy not just because it accords with Christian notions of virtue, but above all because her principled death contains meaning both for Rome and for all those who afterwards hear of it. One final detail is worth noting: Lucrece does away with herself in despite of her companions' sympathy and "ensaumples many oon" (1850). Her legend recalls the oppositional triumph of the saint, and her death suggests an irruption of the absolute into the daily life of ethical compromise. In its appeal to the transcendent, public value of chastity, and in its image of heroic female action, the Legend of Lucrece becomes the subversive counter-example that always threatens the exemplarist's project. 
Lucrece's achievement of a meaningful context for victimization and pain reveals the degree to which the other good women of the Legend remain trapped in a lyricism which "redeems nothing and is redeemed by nothing" (Kolve, "Cleopatra to Alceste" 151). Lament, called into service as the exemplary rhetorical device which marks the good woman as worth the reader's attention, has the paradoxical effect of dissolving the very moral categories which the exemplum traditionally supports. The heroine's isolation is metaphysical as well as literal; her final speech is characteristically addressed to her absent lover, whose indifference is absolute as that of the natural world:

"I may wel lese on yow a word of letter, Al be it that I shal ben nevere the better; For thilke wynd that blew youre ship awey, The same wynd hath blowe awey youre fey."

(Dido 1362-5)

And to the stronde barfot faste she wente, And cryed, "Theseus, myn herte swete! Where be ye, and that I may nat with yow mete, And myghte thus with bestes ben yslayn?" The holwe rokkes answerde hire agayn. No man she saw, and yit shyned the mone ...

(Ariadne 2189-94)

"But syn thus synfully ye me begile, My body mote ye se withinne a while, Ryght in the haven of Athenes fletynge, Withoute sepulture and buryinge, Thogh ye ben harder than is any ston."

(Phyllis 2250-54)

Their speeches do indeed lead to significant moral reasoning 
about their plights, but their outcries and questions cannot, within the world of the poem, be resolved. Eventually the Legend ends and the good women cease to speak, but this is a stop rather than a conclusion.

The Legend's lack of closure has contributed to what Frank calls the "legend of Chaucer's boredom" ( $C$ and the LGW $)--$ the notion, based on the narrator's many remarks about the burden of his imposed task, that he wrote unwillingly and abandoned the collection in a fit of disaffection. My own view of the Legend as a exercise in exemplary writing suggests that these passages may equally well express Chaucer's own awareness of the poetic limits of his chosen form. One example is the well-known complaint, in the Legend of Phyllis, that the poet is "agroted" with his task. Less often quoted, however, is the subsequent passage which gives the reason for his reluctance:

But, for I am agroted herebyforn To wryte of hem that ben in love forsworn, And ek to haste me in my legende (Which to performe God me grace sende), Therfore I passe shortly in this wyse. Ye han wel herd of Theseus devyse In the betraysynge of fayre Adryane That of hire pite kepte him from his bane. At shorte wordes, ryght so Demophon The same wey, the same path hath gon, That dide his false fader Theseus.

(Phyllis, 2454-64)

The argument seems to be that he resents his task not because it is poetically tedious (indeed, this legend is a particularly felici- 
tous example of brief narrative), but because it advances him no further towards his goal: Demophoön is to Phyllis as Theseus was to Ariadne, and in terms of moralitas this new instance represents only a retracing of "the same wey, the same path" (Phyllis, 2463). The collection may stop (and indeed it does, in the middle of a sentence that promises to reveal the tale's "conclusioun" [Hypermnestra 2723]) but it cannot be finished.

The peculiarly indeterminate quality of the Legend of Good Women is, I think, reflected in Chaucer's brief but striking comment about Jason's treatment of Medea:

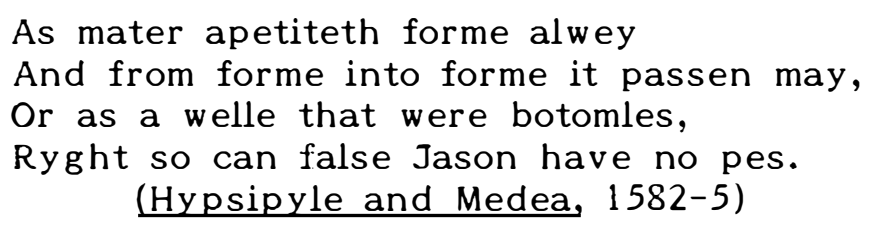

The source for this passage, Guido delle Colonne's Historia Destructionis Troiae, speaks of the bottomless well of female "concupiscentia dissoluta." Chaucer transforms the remark into a reference to Jason's insatiable lust. This tiny instance of adaptation might serve as the paradigm for Chaucer's dealings with his sources in the Legend. He borrows a philosophical generalization, couched in a striking image, and deploys it in a way utterly at variance with his auctor's intention. The passage might also serve as an apt image for the freedom of the poet, whose skills allow him to impose form after form upon the endlessly plastic 
world of his materials. At the same time, however, the comparison of matter and human appetite to a bottomless well lends a troubling inflection to the image. The world of exemplary narrative offers the poet endless an abundance of stories, and scope to experiment with all the ways that narrative may pass "from forme into forme." Yet infinity, except as one of the attributes of God, troubled the medieval sensibility; it implied not just plenitude, but also infinite regress and pointless repetition. One model for this kind of infinity is the compulsive, self-inflicted torments of Dante's damned, who are forever denied the hope, so important to the souls in purgatory, of reaching any summit. Another is the infinite suffering of Troilus. And yet another is the potentially endless Legend itself, a poem which its own poet can never know whether he has satisfactorily completed.

In its soundings of the bottomless well of narrative the Legend anticipates modern poetics, but it is not yet the hermetic, self-generating and self-justifying text of twentieth-century formalism. Chaucer remains part of a cultural milieu which valued the ordered distinction of matter and form, and which grew anxious about experience which resisted meaningful subordination to a system of intellectual categories which derived their absolute authority from the mind of God. The secular impulses within the Legend--the wish to create meanings, and to elaborate the repre- 
sentation of intense human experience in and of itself--inhabit the text as experimental techniques, not as metaphysical assumptions. Frank argues that Chaucer adopts the framework of amour courtois in the Prologue chiefly as a concession to the didactically-minded reader:

It lends an illusion of orthodoxy to the new kind of story he is introducing, which is written at the command of the God of Love and his queen as an act of penance. Unless he behaves too outrageously in the stories that follow, he can, under cover of the fiction he has contrived, do almost anything he wishes. The selection of the theme of "faithful women" permits him to use freely materials in Ovid and other writers, gives him the frame he needs as a vehicle for the "publication" of a series of tales, and leaves him with a toehold on the old orthodoxy of courtly love. He apparently has achieved the maximum maneuverability he felt he could win for himself, granted the character and tastes of his audience and the role he had played as a writer before. (Frank, $\underline{C}$ and the LGW. 35)

I agree with Frank's basic claim that the Legend is an experimental text. I cannot, however, accept his characterizations of the "old orthodoxy of courtly love" or the "moralistic matrix" of the Ovide moralisé (Frank, $\underline{C}$ and the LGW 15) as simply "extraneous

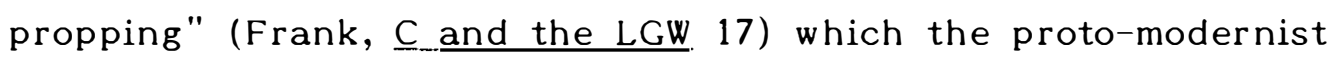
narrator must invoke in order to win the acceptance of an aesthetically conservative and naive audience. We do indeed see Chaucer struggling in the Legend, but in a fashion common to all fabulists and secular writers. And indeed, as I shall attempt to 
show in the next chapter, there is reason to believe that his experiment may not have been wholly satisfying to him. A consideration of the Legend as a specimen of secular, exemplary writing suggests that the very aspects of medieval poetics which have so often been dismissed as obstacles to Chaucer's effort to achieve "pure story"--fidelity to sources, moral categories, and spiritual utility--are in fact boundaries which do not so much impede the experiment as enable it to proceed in an intelligible fashion. 
CHAPTER SIX

CONCLUSION

CHAUCERIAN PATHOS AND CHAUCERIAN PARODY: CANACEE REVISITED

This study has often engaged, in passing, the question of parody and satire in Chaucer. In general I have argued that ironic readings mask the critic's reluctance to engage fully with the sorts of stylistic problems so evident in Chaucer's treatments of pathetic subjects. Incongruity in style (one of the presumed indicators of satiric intent) cannot be identified solely by our own instinctive and often misplaced sense of decorum. Indeed, I have tried to show that in general style in medieval vernacular poetry is a various phenomenon, and that Chaucer's own sensitivity to it is exceptional, as is his adventurous wish to expand the technical resources of English verse.

In making my case for Chaucer's experimentation in the tales of pathos I have attempted to articulate a theory of medieval poetic decorum as the intersection of materia and dispositio. In medieval terms the literary opposition between the sacred and the secular reflects real metaphysical convictions: Rachel mourning her children, Dido grieving for Aeneas, and Ceres lamenting 
the rape of Proserpina are simply not equivalent figures, their similar emotional tenors notwithstanding. Though each story contains some form of truth, these truths are not of interchangeable value, and their literary representations must necessarily assume differing statuses. Much of the stylistic incongruity which modern readers have discerned in Chaucer's tales of pathos arises, I have argued, from the poet's attempt to adapt the style traditionally associated with one kind of text onto another kind, or to extend tendencies already latent in its decorum.

I have, through most of my discussion, avoided any sustained estimate of the poet's own awareness of the effect he creates by these displacements, or of his expectations about how they might affect his readers. We know that the tales of pathos appear a good deal more frequently in late medieval manuscript circulation than their present critical reputation might lead one to expect. In what did the popularity of such tales consist? The answer to such questions may be beyond the reach of documentation and evidence, but in this chapter I will attempt some approach this topic by returning to one of my early examples of secular, exemplary storytelling, the Squire's Tale. This is, of course, a favorite modern candidate for admission to the everexpanding body of Chaucer's "bad tales"--texts which are presumed, because of their peculiarities of form or tone, to express 
Chaucer's satirical view of his subject, of his genre, or of his teller. The issue of parody in the Squire's Tale opens up, I suggest, one way to understand the phenomenon of narrative personae in Chaucer's tales of pathos. It also permits us one final engagement with the larger question of Chaucer's relationship to secular poetics, particularly the tradition of romance. The Squire's Tale, I will argue, is both an instance of secular narration, and also a commentary upon it.

The definition of parody usually employed in ironic readings of Chaucer is simple and commonsensical: parody juxtaposes the style appropriate to one genre with the subject-matter appropriate to another, or perhaps with subject-matter conventionally excluded from literary treatment altogether. The resulting violation of decorum is usually assumed to be satiric, or at least deflating. Familiar Chaucerian instances of this technique include the Biblical language deployed by the lovers in the Miller's Tale, the elevated style applied to beast-fable in the Nun's Priest's. Tale, or the tail-rhyme stanza and outlandish adventures used to celebrate the bourgeois hero of Sir Thopas. I am not particularly concerned that this definition fails to distinguish parody from burlesque and travesty. It will be sufficient for my purposes to note that it treats form as separable from subject-matter, and thus invokes the familiar medieval image of narrative as a stylis- 
tic husk encircling a kernel of significance. Generally speaking: the humor in parody arises from an insistent emphasis upon the meagreness of the fruit in comparison with the rich elaborations of the chaff.

The possibility of parody in the Squire's Tale arises from our inability to interpret it--hence our inclination to label it a "bad tale." This view has the advantage of offering "badness" itself as a hermeneutical category; it allows the interpreter some principle on which to proceed. At the same time, however, this gambit involves certain logical difficulties. Most obvious is the fact that critics are rarely very precise about the nature or function of this bad tale's badness. Is the target of the Squire's Tale the Squire himself, or is it the sort of tale he tells, or is it some combination of these two? The first possibility--that the tale reflects the teller's shortcomings and that, as Joyce E. Peterson puts it, the Squire "tells a trivial tale because he is a trivial person" (Peterson 67)--is, of course, an offshoot of the "roadside drama" theory of the Canterbury Tales, and is in some sense open to all the criticisms that have been levelled against that approach. But even readers who favor dramatic interpretations will have to concede not just that the Squire's Tale is an awfully long joke, but also that the Squire himself is an awfully poor stick on which to hang it. The problem of this view becomes 
evident in the remarks of Stanley Kahrl, who describes the Squire's Tale as dramatizing "the growing impulse toward exoticism and disorder at work in the courts of late medieval Europe," and as containing "in miniature many of the symptoms of the waning of the middle ages" (Kahrl 195, 209). The chivalric neophyte of the General Prologue is certainly young and is arguably foolish, but he hardly seems to deserve all the charges of snobbishness, superficiality, and gaucherie that dramatic readings have called forth, much less the claim that he sums up all the vices of Western culture in decline.

A subtler and altogether more interesting notion is that the Squire's Tale, like Sir Thopas, satirizes certain literary conventions--that is to say, that it is a parody. In particular, a whole series of readers, beginning with Gardiner Stillwell in 1948, have suggested that the tale expresses Chaucer's own ambivalence about chivalric romance. Even here, however, there are difficulties, not least among them the question of how we recognize a parody when we see it. For if the tale expresses Chaucer's impatience with the formal and thematic preoccupations of chivalric literature--if, that is to say, he harbored the suspicion that the representation of ideal emotions and marvelous deeds is just plain silly--how do we account for the occurrence of those conventions elsewhere in Chaucer--for instance, in Troilus and 
Criseyde or the Knight's Tale, where they may generate a certain amount of humor, but certainly cannot be said to become the stuff of parody? A further difficulty with the Squire's relation to the romance tradition arises from the history of the tale's reception. As everyone knows, both Spenser and Milton admired its epic scope and heroic spirit. Even if we allow for all the ways that the Spenserian or Miltonic image of Chaucer differed from our own, we really cannot dismiss either author as lacking discernment and erudition. Their failure to perceive what twentieth-century readers generally regard as the tale's obvious incongruities--its vision, that is, of impossibly exalted ideals compromised by the increasingly bourgeois realities of late medieval knighthood--suggests how differently they appraised Chaucer's contribution to the English tradition of romance.

Most problematic of all is the assumption underlying the whole discussion--namely, that a stylistically elaborate treatment of such manifestly pointless matière reveals Chaucer's wish to discount the very notion of the conte d'adventure. This view of the relation between romance and mock-romance points to a whole cluster of doubtful preconceptions about parody and about the relative value of romance itself. It is, in fact, a circular argument: the artifice of the tale betrays the artifice of the genre, and hence Chaucer's distrust of such artifice. This version of 
the Squire's Tale seems to involve a complete inversion of how parody is normally said to work. By such a train of reasoning one would have to conclude that the Miller's Tale debases Biblical poetry, or that the Nun's Priest's Tale is intended to satirize the epic. But it seems more likely that the Song of Songs, whatever use Absalon may make of it, is not the object of Chaucer's scorn, and that only the unshakable prestige of epic proper makes the mock-epic of the Nun's Priest's Tale possible at all. As Linda Hutcheon puts it in A Theory of Parody, "the presupposition of both a law and its transgression bifurcates the impulse of parody: it can be normative and conservative, or it can be provocative and revolutionary" (Hutcheon 76). In either instance, however, the importance of that law--what I've been calling a kernel of meaning--is never in question. I am, as I have said, sympathetic to the explanatory convenience of regarding the Squire's Tale as somehow "bad"; yet at the same time I must emphasize how often this characterization has rested on unexamined judgments about highly rhetoricized pathos, about the essential absurdity of certain kinds of adventure story, and about the superiority of literary realism--in short, on a sneaking suspicion that certain kinds of highly artificial secular narrative can offer nothing better that a husk without a kernel.

It isn't simple, then, to pin down the Squire's Tale's particu- 
lar type of "badness," or to decide whether Chaucer's intent is satiric, parodic, or--and this is perhaps the most interesting and mysterious possibility of all--perfectly earnest. As I noted in Chapter One, the tale exhibits the concatenating and manufactured qualities of secular text, but readers remain unsure of what the author's dispositio is intended to convey. No definite sources for the tale have been satisfactorily demonstrated, and even the cultural assumptions against which its characters might be judged remain ambiguous. It is clear, however, that whatever nonChaucerian entity may stand behind the Squire's Tale, one very important "source," one to which it may arguably be said to stand in parodic relation, is the Knight's Tale. Not only do the pilgrim-portraits imply the juxtaposition, but the tales themselves naturally invite it: both focus upon a distant aristocratic milieu, both delight in ceremony and beau geste, both define human endeavor primarily in terms of love and war. But while similarities make parody possible, differences are what make it work, and moderns who read the two tales in sequence usually sense a certain deficiency in the Squire's offering. Its contrast with the Knight's Tale ought, therefore, to permit a more rigorous examination of its presumed parodic status.

We can begin to unpack some of these differences by comparing analogous scenes of pathos from the two tales: These- 
us' encounter with the Theban widows, and Canacee's encounter with the falcon. Theseus is newly returned from his triumphant conquest of the Amazons, while Canacee, who has just received the magical ring which enables her to understand the language of birds, has been walking out early in celebration of May. In each case the protagonist, in a time of joy and security, encounters a pathetic victim; in each case this scene of pathos would seem to reveal something about the world of its surrounding tale. The sufferers' plights are emblematic, while the protagonists' compassionate responses seem to be held up as models of ideal action and expressions of noble sensibility.

These formal equivalences, however, merely exaggerate the discrepancies between the narrative elements of which the two episodes are made. The noteworthy differences seem to me to be threefold: first, the transformation of duke Theseus, a military and political hero, into Canacee, a romantic ingenue; second, the shift from a moment of public military triumph to one of private, seasonal recreation; and third, the substitution of a talking bird for the royal widows. These substitutions call our attention to important differences of tone, most notably the greater emphasis in the Squire's account on the violence of the characters' emotions.

Only some of these differences seem to me to be reliably 
indicative of Chaucer's intention. The "downward" shift into the more personal realm of the Squire's Tale is not, I think, especially problematic: as its similarities to "The Bird With Four Feathers" make clear, the fact that the Canacee-episode focuses on private rather than civic action, or that it employs a female protagonist, cannot in and of itself become evidence that the tale deliberately displays its own moral or ethical vacancy. The substitution of a talking bird for the Theban widows is more difficult, and offers much better evidence for deliberate trivialization. Some scholars have discovered Oriental analogues to this bird-motif (Braddy) though no compelling evidence that these were known to Chaucer. Chaucer is, of course, very keen on talking birds, especially when, as in the Nun's Priest's Tale, the Hous of Fame, or the Parliament of Fowls, he can exploit the incongruity, inherent in all beast-fable, of human behavior in animal guise. But the more pointed variety of that exploitation seems absent here: the falcon speaks in an unbroken high style rather like that of the formel eagle and her suitors in the Parliament, where I take the more broadly satiric functions to be borne by the less noble fowls. In other words, one could argue that Chaucer's portrayal of avian sensibility in the Squire's Tale remains, as in the Parliament, at the level of genial comedy, stopping short of full-blown parodic absurdity. 
But as my analysis of Chaucer's other tales of pathos has amply demonstrated, plenty of modern readers find something inane in amorous complaint per se, and that fact suggests that the tonal difference between the Knight's and Squire's Tales--the emotional extravagance of the Squire's version--is the one most requiring our attention. The Theban widows are, of course, an alarming spectacle of pathos: they raise "swich a cry and swich a wo" (A 900) that Theseus "thoughte that his herte wolde breke, / Whan he saugh hem so pitous and so maat" (A 953-4). The Squire's falcon, however, exceeds them in her grief: she has mutilated herself so badly that "the rede blood / Ran endelong the tre ther-as she stood" (F 415-16), and she doesn't just cry out, she "shrighte" (F 417, 422) so loudly and stabs herself so violently with her own beak that, as the narrator assures us, even the cruellest tiger of the forest would be moved to tears, "if that he wepe koude" (F 421). Theseus merely thinks his heart will break with pity for the widows; Canacee, on the other hand, actually feels herself near death: "Ye sle me with youre sorrow verraily" (F 462). It is difficult to resist the impression that in the Squire's Tale the depiction of suffering--which Canacee describes hyperbolically as a "furial pyne of helle" ( $F$ 448)--seems suspiciously disproportionate. For me this incongruity becomes most pronounced in Canacee's question about the 
source of the falcon's grief:

Is this for sorwe of deeth or loss of love?

For, as I trowe, thise ben causes two

That causen moost a gentil herte wo;

Of oother harm it nedeth nat to speke.

(F 450-53)

Bereavement and disappointment in love are indeed powerful movers, but one need only turn to the Knight's Tale to be reminded that the "gentil herte" will also concern itself with whatever offends generosity and justice, reason, order, and the common wealth.

Differences like this one suggest that the Squire's Tale does indeed embody what McCall has described as a "pattern of elaborate inconsequence, incongruity, and downright bathos" (McCall 108). These are also frequent charges against chivalric romance, and so it is attractive to locate the genesis of the tale's "badness" in the inherent limitations of its genre. I would argue, however, that the tale fails less because it incorporates marvelous plot-motifs and ideal character types than because of its narrative perspective on those elements. Like the Knight's Tale, it employs the fictive materials of secular romance, and it promises, again like the Knight's Tale, to treat them in exemplary fashion. In its actual performance of that task, however, it deconstructs, even more fully than the Prologue to the Legend of Good Women, the limitations and discontents potentially attendant upon secular 
poetics.

The Squire is among the most rhetorically self-conscious of the Canterbury pilgrims. His tale is studded with ornamental figures of speech, and with self-reflexive comments upon the nature of his undertaking. The Knight is also a fairly self-conscious narrator, of course, but his comments usually take the form of occupatio, which reveals to the reader something about the selection and focus which govern his story. This feature of his style is well illustrated in the initial descriptions of his heroine. The reader's first view of Emelye is a deft piece of exemplary narrative:

That Emelye, that fairere was to sene Than is the lylie upon his stalke grene, And fressher than the May with floures newe-For with the rose colour stroof hire hewe, I noot which was the fyner of hem two.

Yclothed was she fresshe, for to devyse: Hir yelowe heer was brayded in a tresse Bihynde hir bak, a yerde long, I gesse. And in the gardyn, at the sonne upriste, She walketh up and doun, and as hire list She gadreth floures, party white and rede, To make a subtil gerland for hire hed; And as an aungel hevenysshly she soong. (A $1035-1039,1048-1055$ )

Surely the first thing that strikes any reader of this passage is its very conventionality; Emelye's long blonde braid is the lone detail that seems at all personalized or circumstantial. The description is, however, wonderfully effective. By connecting the 
heroine to flowers and springtime, by emphasizing the freedom of her movement up and down the garden, and by concluding with the lingering polysyllable of "hevenysshly," Chaucer evokes not so much the heroine herself as what she means to the imprisoned knights who are soon to suffer so much on her account. Such thematic affiliations link Emelye's rhetorically-contrived representation in this passage to her role in the larger narrative context. Her youth, beauty, and grace become both morally and artistically intelligible. In short, the description is a skilled demonstration of exemplary style at its most compact and functional.

The Squire's initial description of Canacee, with its elaborate modesty-topos, would at first seem to be in the same bookish vein:
A doghter hadde this worthy kyng also, That yongest was, and highte Canacee. But for to telle yow al hir beautee, It lyth nat in my tonge, n'yn my konnynge; I dar nat undertake so heigh a thyng. My Englisshe eek is insufficient. I most been a rethor excellent, That koude his colours longynge for that art, If he sholde hire discryven every part. I am noon swich, I moot speke as I kan. (F 32-41)

In fact, however, this passage is interesting precisely because of its stubborn insistence that the heroine's beauty cannot simply be acknowledged or evoked; instead it needs to be documented to a degree that exceeds his skills. Where the Knight exploits the 
fact that Emelye is typical (and that therein lies her significance within her tale), the Squire seems concerned about the fact that Canacee is so extraordinary as to defy rhetoric. Chaucer's joke in attributing to the Squire such a misplaced concern for documentary accuracy is, of course, that Canacee is a fiction: she exists not as a real woman to whom the Squire must do descriptive justice, but as a rhetorical construct with no useful existence apart from the poet's own linguistic creation. Or perhaps the joke has to do with the Squire's Coleridge-like inability to record his own imaginative vision of the heroine's perfection. In either interpretation the description of Canacee expresses what, from a medieval point of view, is a rather eccentric view of secular poetry. For all his concern about fine speech, the Squire would seem, at least in this passage, to have misunderstood what such speech is for. What the Squire wishes he could do--"hire discryven every part" (F 40)--is just what the medieval ars poetica was never designed to accomplish. For the Knight, Emelye is intelligible; for the Squire, Canacee remains a bundle of accidents which can be experienced, but never summed up or adequately communicated.

If this pair of examples is typical of the differences between the Knight's and Squire's Tales, then one case for parody in the latter would seem to rest on its tendency to deny the efficacy of 
traditional literary structures. That is, I think, a difference that manifests itself in the tale's attitude towards events as well as towards language. In the Knight's Tale, all human action occurs within a clearly articulated matrix of cosmic structures and ideal behaviors. The tale assumes, as part of its rationale for human behavior and literary decorum, a hierarchy of values that permits both Theseus and his narrator to perceive that some sorrows are more worthy than others. In the Squire's Tale, however, the reader sometimes suspects that the only principle of selection at work is the narrator's fascination with the wondrous, the exceptional, and the superlative. The point of the narrative--its exemplary aim--remains rather murky. Thus while the "badness" of the Squire's Tale may first strike us as primarily related to its genre and its stylized rhetoric, comparison with similar features in the Knight's Tale shows that these are merely symptomatic or more profound narrative difficulties.

Some evidence for these difficulties comes in Part One, when Cambyuskan's courtiers discuss the steed of brass which their emperor has just received as a birthday gift:

Diverse folk diversely they demed;

As many heddes, as many wittes ther been. They murmureden as doothe a swarm of been, And maden skiles after hir fantasies, Rehersyng of thise olde poetries, And seyden it was lyk the Pegasee, The hors that hadde wynges for to flee; Or elles it was the Grekes hors Synon, 
That broghte Troie to destruccion, As men moun in thise olde geestes rede. "Myn herte," quod oon, "is everemoore in drede; I trowe som men of armes been therinne, That shapen hem this citee for to wynne. It were right good that al swich thyng were knowe." Another rowned to his felawe lowe, And seyde, "He lyeth, for it is rather lyk An apparence ymaad by som magyk, As jogelours pleyen at thise festes grete." (F 202-19)

It is very tempting to construe this steed of brass, which can

"Beren youre body into every place / To which youre herte wilneth for to pace, / withouten wem of yow, thurgh foul or fair" (F 119-21), as an image of poetry itself, and to read the courtiers' comments in literary terms. Everyone at Cambyuskan's court agrees about the steed's perfect lifelikeness, we are told, but not about its significance. For some its powers of flight recall those of Pegasus, while others fear that this gift horse may, like the Trojan one, conceal an enemy. In particular we should note that the courtiers try to understand the steed of brass in terms of other, better-known exemplary horses: one from classical mythology (Pegasus), and one from history (the Trojan horse). It also seems significant that the courtiers' interest is fairly pragmatic--they want to know whether the horse poses a threat, or is a mere theatrical gimcrack.

The Squire dismisses their speculations as "jangling" and "fantasies" drawn from old books: 
Of sondry doutes thus they jangle and trete, As lewed peple demeth comunly

Of thynges that ben maad moore subtilly

Than they kan in hir lewednesse comprehende.

As soore wondren somme on cause of thondre, On ebbe on flood, on gossomer, and on myst, And alle thyng, til that the cause is wyst. Thus jangle they, and demen, and devyse, Til that the kyng gan fro the bord aryse. (F 220-223, 258-262)

Usually this passage is taken to reveal something about the Squire's attitude toward "lewed peple," or about Chaucer's interest in pluralism ("Diverse folk diversely they demed"). I would argue that it is far more interesting to regard the passage as a comment on interpretive method, and on the poetic principles which govern the tale as a whole. In deriding the courtiers' hermeneutic efforts, the Squire rejects "olde poetries" and "olde geestes": he privileges novelty over tradition and wonder over interpretation. Just as he insisted that rhetoric could not do justice to the beauty of Canacee, so he here asserts the unique and absolute quality of the brazen steed. The horse, he says, and by analogy the poem itself, are no more amenable to tidy explanation than are the phenomena of nature; their workings are fundamentally mysterious, and those who puzzle themselves with niceties of interpretation are no more likely to succeed than those who "wondren... on cause of thonder, / On ebbe, on flood, on gossomer, and on myst" (F 258-9). 
The Squire does not deny the presence of meaning, but he asserts its independence from such traditional sources of form and significance as history and classical fable. In a sense he displays the contents of his tale as if they possessed self-evident, direct importance, and required no authorial elucidation. He treats them, in short, as if they were iconic. They are not, of course, and the Squire's refusal to assume the secular poet's burden of demonstration--indeed, his manifest contempt for that burden--accounts for much of the tale's weird obliquity. The readerly community implied by the tale is, in a sense, a coterie of "gentil hertes" whose sensibilities are already formed prior to their experience of the text, and who recognize one another by their shared appreciation of elegant marvels. And finally I would argue that both the tale's narrator and the sort of literary sensibility he represents are conscious fictions, the product of the author behind the teller's mask.

It is suggestive, therefore, to think about the Squire's Tale as somehow related to a poetics of innovation and originality. Despite my own interest in the experimental nature of the tales of pathos, I am, like most Chaucerians, accustomed to viewing Chaucer as preoccupied with the difficulties of living up to the traditions of the literary past. In both subject-matter and style the

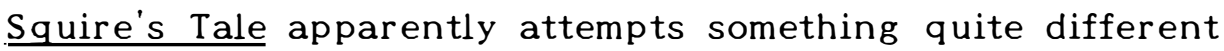


from--indeed, something in opposition to--the sort of poetry Chaucer so clearly valued. The Squire's interest in sentiment and in the imagined opulence of faraway places, his recurrent frustration at the incapacity of language to convey all the minute particularities of his vision, and his insistence that meaning is delicate and evanescent as a cloud all anticipate, in interesting ways, certain quite modern views of literature. The author's text becomes a beautiful artifact, and aesthetic experience acquires privilege precisely because of its distinctively imaginary qualities. Barbara Herrnstein Smith gives a clear and representative statement of this aspect of modern fiction's status:

The work of art, then, provides the stimulus to and occasion for a highly distilled and rewarding cognitive experience, but also a highly artificial one; for in experiencing a work of art, we may have all the satisfaction that attends the pursuit and acquisition of knowledge without necessarily having acquired any knowledge at all. Or, rather, what we acquire knowledge of in a work of art is primarily the work itself, a fabricated microcosm designed to be knowable in just that way. What is most important here is that although this knowledge obviously has its sources in nature and reflects it in various ways, it cannot be generalized to nature as we generalize knowledge in science--or indeed in our ordinary experience--from one part of nature to another. (Smith 12)

If this characterization of literature is at all applicable to the Squire's Tale, it considerably complicates the question of the tale's parodic status. It gives, in fact, an entirely new context to its "pattern of elaborate inconsequence" (McCall 108), for it sug- 
gests that poetry necessarily establishes its own cognitive universe, separate from and unaccommodated to the rules that govern other parts of our lives. We ought, perhaps, to entertain the notion that the Squire's Tale represents a newly autonomous version of poetry, and that it may be Chaucer's most radically secular and innovative text.

This notion of a literary art independent of received explanatory categories is familiar, of course, from the renaissance of the twelfth century, and especially from the inventive burst that created chivalric romance. Despite Chrétien de Troyes' avowed interest in the translatio of chivalry and learning, it seems beyond question that a large measure of the appeal that Celtic legend held for him was its very lack of fixed, traditional meaning. Unlike the narrative materials he could have found in the Bible, in ancient or modern chronicle, or in Ovidian fable, the matière of the Grail story, for instance, was entirely potential, tantalizingly inchoate, ready for the artist's shaping conjointure. In contrast to the familiar medieval notion that the truth, though always the same, can be enclosed in a variety of fictive coverings, Chrétien's artistry proposes the very modern principle that a single husk may cover a plurality of kernels.

But the radical suggestiveness of his romances is disquieting, as the controversy about the "Joie de la Cour" episode in 
Erec and Enide demonstrates. Anthropological critics in this century have been unduly anxious to uncover the "real" meaning of Arthurian legend, while the author or authors of the Vulgate Queste del Saint Graal responded to the romancer's innovations by producing, within fifty years of Chretien's version, a fully exemplary Grail legend, rationalized and accommodated to the traditions of Biblical history and hermeneutic. Like the courtiers in the Squire's Tale, they assumed that a narrative's intelligibility lies precisely in its links with literary and historical exemplars.

The Cistercian author of the Vulgate Queste is, of course, a cleric and a moralist, and that fact may make his discomfort with the indeterminacy of romance a poor model of judgment on the courtly milieu which both Chrétien and Chaucer inhabit. But his response merely exaggerates the caution with which all claims to detach literature from life have, at virtually all periods of European history, been met. In the eighteenth century, when secular narrative becomes the norm, the "cult of sensibility" becomes controversial precisely because it tends to detach affect from daily moral imperatives. Anna Laetitia Barbauld, devotional author and editor of Richardson's collected letters, discusses the supposedly humane and edifying effects of "agreeable distress" in terms which do much to clarify the disturbing effect of the Squire's. Tale: 
By the constitution of our frame our habits increase, our emotions decrease, by repeated acts; and thus a wise provision is made, that as our compassion grows weaker, its place should be supplied by habitual benevolence. But in these writings our sensibility is strongly called forth without any possibility of exerting itself in virtuous action, and those emotions, which we shall never feel again with equal force, are wasted without advantage. Nothing is more dangerous than to let virtuous impressions of any kind pass through the mind without producing their proper affect. The awakenings of remorse, virtuous shame and indignation, the glow of moral approbation--if they do not lead to action, grow less and less vivid every time they recur, till at length the mind grows absolutely callous. The being affected with a pathetic story is undoubtedly the sign of an amiable disposition, but perhaps no means of increasing it. On the contrary, young people, by a course of this kind of reading, often acquire something of that apathy and indifference which the experience of real life would have given them, but without its advantages. (Barbauld 227-8)

Her emphasis on the separability of active virtue from mere reader-response certainly foreshadows the formalist definition of the work of art as "fabricated microcosm." But equally clearly she regards the divorce between feeling and action as an all-toocommon abuse rather than as a necessary feature of aesthetic experience.

Chaucer, I would argue, is the precursor to Mrs. Barbauld rather than to Barbara Herrnstein Smith. He creates a form of narrative that seems to anticipate certain modernist aesthetic and metaphysical assumptions, but he does not embrace them as his own. One indication of his wariness about the radical secularity 
of the Squire's Tale is the presence of the courtiers whose traditional and pragmatic wish to know what things mean challenges the Squire's airy absorption in wonder. Another is his choice of a pilgrim-narrator whose youth and inexperience make him an apprentice not just to knighthood and poetry, but to life itself. Yet another is the counter-exemplum of the Knight's Tale, where public norms of virtue and order are all that stand between civilization and the reign of Saturn. All these facts serve to distance the tale from its ultimate poet, and to make our suspicions of irony secure. Chaucer includes within the tale the information that allows us to place it. It is both an example of radically secular narrative, and a comment upon such narrative.

The choice of romance for the Squire's Tale is particularly apt. Whether that choice involves a satiric rejection of romance is more difficult to discern, and for reasons arising from something I have already mentioned about parody: namely, its radically derivative nature. In its original meaning, of course, parody is a parodia--a song whose existence and significance depend on some earlier song. In a medieval context, however, this notion of dependence entails a great deal more than mere literary genealogy. To say that poetry must have some intelligible relation to the great literary exemplars of the past, and especially to Scripture, is no more that to give one example of the principle by 
which the historical events in the Old Testament find fulfillment in the New, or by which all saints' lives recapitulate the life of Christ. Both individuals and nations may choose, through willfulness or ignorance, to efface the patterns on which action ought to be based. In moral terms the result is usually called sin, and insofar as the quest for false goods assumes an appearance of right action without the kernel of its proper object, the result is always parodic. What then of the romancer, the secular poet who chooses to sever his ties to the literary patterns that traditionally lend poetry its intelligibility? From the traditional point of view that I've just been describing, the search for wholly new ways of signification is by its very nature doomed to a kind of inanition that is properly called parodic. In these terms the question of whether the Squire's Tale is a parody of romance assumes a new dimension: it becomes quite enough to say simply that it is a romance, and that in discarding the exemplary fruits of literary tradition it acquires the risibility that we moderns associate with parody. Whether the Squire's Tale is a straightforward attempt at romance or a calculated satire of it, its virtually unique place in the Chaucer canon suggests that its author felt certain reservations about the kind of plastic freedom to forge previously unperceived meanings which Chrétien celebrates in his prologues. For insofar as the secular poet must always 
come after, his position is always parodic in the root sense, and, as the Squire's Tale demonstrates, potentially parodic in the modern sense as well.

The Squire's Tale' self-consciousness about narrative and its potential functions is, in some ways, the kind of irony associated with dramatic readings of the Canterbury Tales. It is not, however, quite the sort of personal reflection upon the teller that clearly operates in the Wife of Bath's or Pardoner's Tales. Rather it is a reflection upon narrative itself. In employing the persona of the Squire, Chaucer allows himself certain freedoms to experiment with form and style--and to do so without assuming the full burden of authorial responsibility. The faceless, nameless narrator of the Second Nun's Tale manifests Chaucer's secure commitment to the status of hagiography, while the Man of Law, Prioress, Squire, and even the self-mocking dreamer of the Prologue to the Legend are expressions of the more contested status of those texts' narrative strategies. The Chaucerian ironic persona supplies a context for experimentation in secular storytelling, and a way of acknowledging its limits without valorizing them.

Thus like all of Chaucer's tales of pathos, the Squire's Tale is experimental. Exploiting the capacity of language to depict suffering and evoke "pite," the tales of pathos attempt a kind of poetry whose claim on the reader is textual rather than ideologi- 
cal, whose power to affect the reader's sensibility rises from the experience of reading itself, and not from the sanctified, iconic authority of the story's pre-existent subject-matter. The fiction becomes important because the author has made it so. But we should hasten to add that these experiments--however audacious and modern they seem in their anticipation of the autonomous, self-constituted verbal icon--remain innovative chiefly at the technical level. That is, although they do new and remarkable things with words, they do not take the further step of elevating linguistic structures into metaphysical principles. As court-poet rather than clerk, Chaucer strives to invent a secular poetry which, squeezing all it can from rhetoric and from the experiential textures of life in the world, achieves the transcendent and transforming power of the iconic. As the Legend of Good Women wittily shows, however, this experiment is at best a qualified success. The confrontation with pure suffering, in and of itself, cannot rise from the experiential to the intelligible; and in the Legend of Good Women, with its exemplary moral program which contains but does not fully explain the good woman's display of pain, Chaucer seems to accept that limitation.

The elaborately framed Canterbury tales of pathos are more successful in their depiction of suffering. From a technical standpoint they offer a subtle and fascinating example of inter- 
textuality. Chaucer's borrowings and adaptations expose his effort to find poetically- rather than ideologically-conceived meanings, and foreshadow the mechanisms which were later to produce a fully secular poetry in English. But as we can see from the religiously-oriented subject-matter and invented narrators of the Man of Law's and Prioress's Tales, Chaucer was not prepared to assume further responsibility for a poetry of self-generated and self-contained signification. He remained committed to determinacy, authority, tradition, and faith--not out of mindless obedience, but from a conviction that these alone allow the poet to work with a full assurance that his words will reflect and participate in the true and divinely instituted significance of things. Finally he is willing to forgo his niche in the House of Fame in favor of a place on "this viage, / Of thilke parfit glorious pilgrymage / That hight Jerusalem celestial" (ParsProl I, 49-51)--a journey which, however metaphorical, is also real.

The study of Chaucerian pathos thus has implications for our understanding of other portions of the Chaucer canon, and finally for our image of the poet himself. No one any longer subscribes to the image of a "wide-eyed, jolly, rolypoly little man who, on fine Spring mornings, used to get up early, while the dew was still on the grass, and go look at daisies" (Donaldson, "Chaucer the Pilgrim" 2). By discarding what Donaldson aptly 
characterizes as a naive view of Chaucer we at least restore to the poet the craft, sophistication, and erudition which dominated his reputation in the centuries immediately following his death. But in doing so we have also produced a curiously bifurcated state of Chaucer studies. One branch of interpretation emphasizes Chaucer's modernity. Originally inspired, perhaps, by the rich textures of language and imagery which make his poetry able to withstand the scrutinizing procedures of the New Criticism, such readers attend mostly to immediacies of tone: ambiguity, tension, and verbal irony become the key constituents of Chaucer's style, while his debt to inherited conventions of imagery and rhetoric tends to recede into the background. This Chaucer is above all interested in the powers of fresh, original language to mirror and even to remake the world. By privileging his power to invent, however, such Chaucerians also often import formalist assumptions about the literary enterprise as a whole: that Chaucer's humor and verbal dexterity imply a vision of poetry as a very sophisticated form of play, that his interest in multiple points of view implies ethical relativity and skepticism towards absolute values, and that his complex, resonant structures imply his commitment to all the epistemological and metaphysical assumptions contained in the modern word "text." This view of Chaucer as the ultimate artificer who transcends the 
clumsy, naive literature of didacticism and moral utility is, obviously, a reflection of what we ourselves often think poets and poetry should be.

In contrast with this "formalist Chaucer" is the historically reconstructed poet of medieval values. Critics in this branch tend to regard Chaucer's language not as a self-generated and self-validating web, but as a relatively transparent vehicle for his ideas. This Chaucer is unequivocally a product of his age, and the meaning of his poems resides not in artifice, but in their relation to the ethical, extraliterary norms which make up the poet's cultural milieu. The critic's task is precisely to work out such congruences of language and principle, and her interest is thus drawn to Chaucer's use of conventional motifs, strategies of closure, and dramatic rather than verbal ironies.

Most twentieth-century medievalists do, of course, exploit both versions of Chaucer--the work of E. Talbot Donaldson, for instance, is a good example of how these two set of assumptions can cross-fertilize literary interpretation. If I have exaggerated and dichotomized them, it is only to clarify what I take to be their common limitation. "Historicist" Chaucerians can offer us a poetics of authentic moral weight, but with little insight into its qualities as poetry; "formalist" Chaucerians do justice to Chaucer's technical complexity, but tend to trivialize or reject his 
commitment to the important ideas of his time. In short, neither view really confronts Chaucer's preoccupation with literary efficacy, his wish to construct, simultaneously, persuasive narratives and narrative persuasions. One might say that formalists grant Chaucer's poetry the power to enact meaning even as they deny the possibility that such meaning has ultimate value, while historicists permit Chaucer to serve certain intellectual absolutes, but only as a kind of poor handmaid to theology.

What both these views of Chaucer lack, finally, is a sense of how moral and literary experience intersect; they both reflect, despite their differing assumptions of value, the modern dissociation of literature from other forms of discourse. Literary pathos, whether Chaucer's or someone else's, gives us trouble precisely because it insists on re-establishing that connection. In its focus on the observer's complex response to another's distress, pathos insists on life as an experiential and moral continuum, and expresses our continuing need to interpret the welter of our perceptions. Chaucerian pathos, at least as I have analyzed it, points up Chaucer's own effort to make secular poetry a more effective instrument of that orientation.

He is not, as we have seen, always successful. Often his tales of pathos seem to have the effect of the Physician's Tale on the unregenerate Harry Bailly, who grasps both the moral point 
and the emotional impact of Virginia's death without entirely taking either of them to heart: "This is a pitous tale for to heere. / But nathelees, passe over; is no fors" (IntroPardT, C 302-3). But Chaucer's efforts should, I think, move as well as puzzle and challenge us. I have emphasized how the tales of pathos exhibit certain technical innovations which anticipate later developments in English literature, and this feature alone makes them interesting: Chaucer undertakes stylistic adaptations and generic experiments which push narrative in new directions. But these efforts to expand the freedom of the poet are not sui generis; they are part of his commitment to making the secular art of story-telling serve the aims of the ultimate Auctor.

If finally modern readers reject the style of Chaucer's scenes of pathos, the preference may be less a matter of decorum than of conviction: we are no longer so certain of what can be made of the death of innocence and the sadness it brings. Our age of radical uncertainty has made it difficult to apprehend the confidence with which Chaucer invokes absolutes. Yet poetry which arises from the contemplation of creatural frailties addresses something which we have surely not discarded along with the Prioress's simple pieties--namely our wish to find a use for suffering and a meaning in pain, even if we are no longer sure that wish can be fulfilled. 
Ames, Ruth M. "The Feminist Connections of Chaucer's Legend of Good Women." In Chaucer in the Eighties. Ed. Julian N. Wasserman and Robert J. Blanch. Syracuse: Syracuse University Press, 1986. Pp. 57-74.

Apocryphal Gospels, Acts, and Revelations. Tr. Alexander Walker. Ante-Nicene Christian Library, Vol. 16. Edinburgh: T. \& T. Clark, 1870.

Aquinas, St. Thomas. Summa Theologica. Tr. Anton C. Pegis. In Introduction to Saint Thomas Aquinas. New York: Modern Library, 1948.

Auerbach, Erich. "Sermo Humilis." In Literary Language and Its Public in Late Latin Antiquity and in the Middle Ages. Tr. Ralph Manheim. London: Routledge and Kegan Paul, 1965. Pp. 25-82.

Augustine, St. De doctrina Christiana. Tr. D.W. Robertson, Jr., as On Christian Doctrine. Library of Liberal Arts 80 . New York: Liberal Arts Press, 1958.

---. Enarrationes in Psalmos. PL 36.

--. Expositions On the Book of Psalms. Ed. and Tr. A. Cleveland Coxe. Select Library of the Nicene and Post-Nicene Father of the Christian Church, Vol. 8. 1888. Rpt. Grand Rapids, MI: Eerdmans, 1983.

---. Sermons on the Liturgical Seasons. Tr. Sr. Mary Sarah Muldowney. The Fathers of the Church, Vol. 38. New York: Fathers of the Chuch, 1959.

Avril, François. Manuscript Painting at the Court of France: The Fourteenth Century. Trans. Ursule Molinaro and Bruce Benderson. New York: Braziller, 1978.

Barbauld, Anna Laetitia. "Inquiry into those Kinds of Distress which Excite agreeable Sensations." In The Works of Anna Laetitia Barbauld. 2 vols. Ed. Lucy Aikin. London: Longman, Hurst, Rees, Orme, Brown, and Green, 1825. Vol 2: 214-31. 
Belting, Hans. The Image and Its Public in the Middle Ages: Form and Function of Early Paintings of the Passion. 1981. Tr. Mark Bartusis and Raymond Meyer. New Rochelle, NY: Aristide Caratzas, 1990.

Bennett, J.A.W. Poetry of the Passion: Studies in Twelve Centuries of English Verse. Oxford: Clarendon Press, 1982.

Benson, C. David. "Varieties of Religious Poetry in The Canterbury Tales: The Man of Law's Tale and The Clerk's Tale." Studies in the Age of Chaucer, Proceedings, no 2 (1986): 159-68.

Berlioz, Jacques. "Le récit efficace: l'exemplum au service de la prédication (XIII ${ }^{\mathrm{e}}-\mathrm{XV}^{\mathrm{e}}$ siècles)." Melanges de l'École Francaise de Rome, 92 (1980): 113-46.

Bernard, St. (attr.). Liber de passione Christi. PL 182:1133-42.

-... On the Song of Songs. Tr. Kilian Walsh. Cistercian Fathers Series. Shannon, Ireland: Irish University Press, 1971.

Bestul, Thomas H. "The Man of Law's Tale and the Rhetorical Foundations of Chaucerian Pathos." Chaucer Review, 9 (1975): 216-26.

Block, Edward A. "Originality, Controlling Purpose, and Craftsmanship in Chaucer's Man of Law's Tale." PMLA, 68 (1953): 572-616.

Bloomfield, Morton $W$. "The Man of Law's Tale: A Tragedy of Victimization and a Christian Comedy." PMLA, 87 (1972): 384-90.

Boccaccio, Giovanni. De claris mulieribus. Tr. Guido A. Guarini as Concerning Famous Women. New Brunswick, NJ: Rutgers University Press, 1963.

Bokenham, Osbern. Legendys of Hooly Wummen. Ed. Mary S. Serjeantson. EETS o.s. 206. London, 1938.

Bonaventure, St. Breviloquium. Tr. José de Vinck. The Works of Bonaventure Vol. II. Paterson, NJ: St. Anthony Guild Press, 1963. 
-.-. Itinerarium Mentis in Deum. Ed. and tr. Philotheus Boehner. Works of Saint Bonaventure Vol II. Saint Bonaventure, NY: The Franciscan Institute, 1956.

Boureau, Alain. La légende dorée: Le système narratif de Jacques de Voragine. Paris: Les Éditions du Cerf, 1984.

Boyer, Régis. "An Attempt to Define the Typology of Medieval Hagiography." In Hagiography and Medieval Literature. Ed. Hans Bekker-Nielsen, Peter Foote, Jørgen Højgaard J $\phi$ rgensen, and Tore Nyberg. Odense: Odense University Press, 1981. Pp. 27-36.

Braddy, Haldeen. "The Genre of Chaucer's Squire's Tale." JEGP, 41 (1942): 279-90.

Bremond, Claude, Jacques LeGoff, and Jean-Claude Schmitt. L'"exemplum". Typologie des sources du Moyen Age occidental, fasc. 40 (1982).

Brody, Saul Nathaniel. "Chaucer's Rhyme Royal Tales and the Secularization of the Saint." Chaucer Review, 20 (1985-6): 113-21.

Brown, Carleton, ed. English Lyrics of the XIIIth Century. London: Oxford at the Clarendon Press, 1932.

---, ed. Religious Lyrics of the XIVth Century. 2nd ed. Rev. G.V. Smithers. London: Oxford at the Clarendon Press, 1957.

Brown, Peter. The Cult of the Saints: Its Rise and Function in Latin Christianity. Chicago: University of Chicago Press, 1981.

Brumble, H. David, III. "Chaucer's General Prologue: Canterbury Tales." The Explicator, 37 (1978): 45.

Caesarius of Heisterbach. The Dialogue on Miracles. Tr. H. von E. Scott and C.C. Swinton Bland. 2 vols. New York: Harcourt, Brace, 1929.

Caxton, William. The Golden Legend or Lives of the Saints. 7 vols. 1900. Rpt. New York: AMS Press, 1973.

Chaucer, Geoffrey. The Riverside Chaucer. 3rd ed. Ed. Larry D. Benson. Boston: Houghton-Mifflin, 1987. 
Chenu, M.D. "The Symbolist Mentality." 1957. Rpt. in Nature, Man, and Society: Essays on New Theological Perspectives in the Latin West. Tr. Jerome Taylor and Lester K. Little. Chicago: University of Chicago Press, 1968.

Collette, Carolyn P. "Critical Approaches to the Prioress's Tale and the Second Nun's Tale." In Chaucer's Religious Tales. Ed. C. David Benson and Elizabeth Robertson. Cambridge: D.S. Brewer, 1990. Pp. 95-110.

---. "Sense and Sensibility in the Prioress's Tale." Chaucer Review, 15 (1980-81): 138-50.

David, Alfred. "An ABC To the Style of the Prioress." In Acts of Interpretation: The Text in its Contexts 700-1600. Ed. Mary J. Carruthers and Elizabeth D. Kirk. Norman, OK: Pilgrim Books, 1982. Pp. 147-57.

Davies, R.T., ed. Medieval English Lyrics: A Critical Anthology. Evanston [?]: Northwestern University Press, 1964.

Deanesly, Margaret. The Lollard Bible and Other Medieval Biblical Versions. Cambridge: Cambridge University Press, 1920.

Delany, Sheila. "Rewriting Woman Good: Gender and Influence in Two Late-Medieval Texts." In Chaucer in the Eighties. Ed. Julian N. Wasserman and Robert J. Blanch. Syracuse: Syracuse University Press, 1986. Pp. 75-92.

Delasanta, Rodney. "And of Great Reverence: Chaucer's Man of Law." Chaucer Review, 5 (1970-71): 288-310.

Delehaye, Hippolyte. The Legends of the Saints. Tr. V.M. Crawford. 1907. Rpt. Notre Dame, IN: University of Notre Dame Press, 1961.

Dembowski, Peter F. "Traits essentiels des récits hagiographiques." In La nouvelle: formation, codification et rayonnement d'un genre médiéval. Ed Michelangelo Picone, Giuseppe DiStefano, and Pamela D. Stewart. Montreal: Plato Academic Press, 1983. Pp. 80-88.

de Vitry, Jacques. The Life of Marie d'Oignies. Tr. Margot $\mathrm{H}$. King. Saskatoon, Saskatchewan: Peregrina Publishing, 1986. 
Dialogus Beatae Mariae et Anselmi de passione Domini. PL 159:27190.

Donaldson, E.Talbot. "Chaucer the Pilgrim." In Speaking of Chaucer. New York: Norton, 1970. Pp. 1-12.

-.-. "The Masculine Narrator and Four Women of Style." In Speaking of Chaucer. New York: Norton, 1970. Pp. 46-64.

Duffey, Bernard I. "The Intention and Art of the Man of Law's Tale." ELH, 14 (1947): 181-93.

Dunbar, William. Poems. Ed. James Kinsley. London: Oxford at the Clarendon Press, 1958.

Dunn, E. Catherine. "The Saint's Legend as History and as Poetry: An Appeal to Chaucer." American Benedictine Review, 27 (1976): 357-78.

Edmund of Pontigny. Le Merure de Seinte Eglise. Ed. Harry Wolcott Robbins. Lewisburg, PA: privately printed, 1923.

Farrell, Robert T. "Chaucer's Use of the Theme of the Help of God in the Man of Law's Tale." Neuphilologische Mitteilungen, 71 (1970): 239-43.

Finucane, Ronald C. Miracles and Pilgrims: Popular Beliefs in Medieval England. London: J.M. Dent, 1977.

Frank, Robert Worth, Jr. Chaucer and the Legend of Good Women. Cambridge: Harvard University Press, 1972.

---. "Miracles of the Virgin, Medieval Anti-Semitism, and the 'Prioress's Tale." In The Wisdom of Poetry. Ed. Larry D. Benson and Siegfried Wenzel. Kalamazoo, MI: Medieval Institute Publications, 1982. Pp. 177-88.

---. "Pathos in Chaucer's Religious Tales." In Chaucer's Religious Tales. Ed. C. David Benson and Elizabeth Robertson. Cambridge: D.S. Brewer, 1990. Pp. 39-54.

Frye, Northrop. Anatomy of Criticism: Four Essays. Princeton: Princeton University Press, 1957.

Garrett, R.M. "'Cleopatra the Martyr' and Her Sisters." JEGP, 22 (1923): 64-74. 
Geary, Patrick. "Humiliation of Saints." In Saints and Their. Cults: Studies in Religious Sociology, Folklore and History. Ed Stephen Wilson. Cambridge: Cambridge University Press, 1983. Pp. 123-40.

Gesta Romanorum. Ed. Sidney J.H. Herrtage as The Early English Versions of the Gesta Romanorum. London: EETS e.s. 33 (1879).

Giffin, Mary. "Hir Hous the Chirche of Seinte Cecilie Hight." In Studies on Chaucer and His Audience. Quebec: Éditions L'Éclair, 1956. Pp. 29-48.

Goddard, H.C. "Chaucer's Legend of Good Women." JEGP, 7 (1908): 87-129.

Goodich, Michael. Vita Perfecta: The Ideal of Sainthood in the Thirteenth Century. Stuttgart: Anton Hiersemann, 1982.

Gray, Douglas. "Chaucer and 'Pite." In J.R.R. Tolkien, Scholar and Storyteller: Essays in Memoriam. Ed. Mary Salu and Robert T. Farrell. Ithaca: Cornell University Press, 1979. Pp. 173-207.

--- Themes and Images in the Medieval English Religious Lyric. London: Routledge and Kegan Paul, 1972.

Green, Richard Leighton, ed. The Early English Carols. 2nd ed. Oxford: Oxford University Press, 1977.

Gregory the Great, St. Dialogues. Tr. Odo John Zimmerman. The Fathers of the Church, Vol 39. Washington, DC: Catholic University of America Press, 1959.

Hamilton, Marie Padgett. "Echoes of Childermas in the Tale of the Prioress." In Chaucer: Modern Essays in Criticism. Ed. Edward Wagenknecht. London: Oxford University Press, 1959. Pp. 88-97.

Heffernan, Thomas J. Sacred Biography: Saints and Their Biographers in the Middle Ages. New York: Oxford University Press, 1988.

Howard, Donald R. The Idea of the Canterbury Tales. Berkeley: University of California Press, 1976.

Hugh of St. Cher. Opera Omnia. Venice, 1732. 
Hutcheon, Linda. A Theory of Parody: The Teachings of Twentieth-Century Art Forms. New York: Methuen, 1985.

Jacobus de Voragine. Legenda Aurea. Ed. T. Graesse. 3rd ed. 1890. Rpt. Osnabrück: Otto Zeller Verlag, 1969.

Jauss, Hans Robert. "Levels of Identification of Hero and Audience." NLH, 5 (1973-4): 283-317.

Johnson, William C., Jr. "The Man of Law's Tale: Aesthetics and Christianity in Chaucer." Chaucer Review. 16 (1981-2): 20121 .

Jones, W.R. "Lollards and Images: The Defense of Religious Art in Later Medieval England." Journal of the History of Ideas, 34 (1973): 27-50.

Kahrl, Stanley J. "Chaucer's Squire's Tale and the Decline of Chivalry." Chaucer Review, 7 (1972-3): 194-209.

Kane, George. Middle English Literature: A Critical Study of the Romances, the Religious Lyrics, Piers Plowman. London: Methuen, 1951.

Kean, P.M. Chaucer and the Making of English Poetry. 2 vols. London: Routledge and Kegan Paul, 1972.

Keiser, George R. "The Middle English Planctus Mariae and the Rhetoric of Pathos." In The Popular Literature of Medieval England. Ed. Thomas J. Heffernan. Tennessee Studies in Literature, Volume 8. Knoxville: University of Tennessee Press, 1985. Pp. 167-93.

Kemmler, Fritz. Exempla in Context: A Historical and Critical Study of Robert Mannyng of Brunne's "Handlyng Synne". Tübingen: Gunter Narr Verlag, 1984.

Kiser, Lisa J. Telling Classical Tales: Chaucer and the Legend of Good Women. Ithaca: Cornell University Press, 1983.

Knoepflmacher, U.C. "Irony Through Scriptural Allusion: A Note on Chaucer's Prioresse." Chaucer Review, 4 (1969-70): 18083.

Kolve, V.A. Chaucer and the Imagery of Narrative: The First Five Canterbury Tales. Stanford: Stanford University Press, 1984. 
-.-. "Chaucer's Second Nun's. Tale and the Iconography of Saint Cecilia." In New Perspectives in Chaucer Criticism. Ed. Donald M. Rose. Norman, OK: Pilgrim Books, 1981. Pp. 13774.

--. "From Cleopatra to Alceste: An Iconographic Study of The Legend of Good Women." In Signs and Symbols in Chaucer's Poetry. Ed. John P. Hermann and John J. Burke, Jr. University, Alabama: University of Alabama Press, 1981. Pp. 179-94.

Kurth, Willi. The Complete Woodcuts of Albrecht Dürer. Trans. Silvia M. Welsh. 1927. Rpt. New York: Dover Publications, 1963.

Lawton, David. Chaucer's Narrators. Cambridge: D.S. Brewer, 1985.

Love, Nicholas. The Mirrour of the Blessed Lyf of Jesu Christ: A Translation of the Latin Work Entitled Meditationes Vitae Christi Attributed to Cardinal Bonaventura. Ed. Lawrence F Powell. Oxford: Clarendon Press, 1908.

Lowes, John L. "Is Chaucer's Legend of Good Women a Travesty?" JEGP, 8 (1909): 513-69.

Madaleva, Sister M., C.S.C. "Chaucer's Nuns." In A Lost Language and Other Essays on Chaucer. New York: Sheed and Ward, 1951.

Manning, Robert. Meditations on the Supper of our Lord, and the Hours of the Passion, by Cardinal John Bonaventura, Drawn into English Verse by Robert Manning of Brunne (about 1315-1330). Ed. J. Meadows Cowper. EETS 0.s. 60. London, 1875.

Manning, Stephen. "Chaucer's Constance, Pale and Passive." In Chaucerian Problems and Perspectives: Essays Presented to Paul E. Beichner, C.S.C. Ed. Edward Vasta and Zacharias P. Thundy. Notre Dame: University of Notre Dame Press, 1979. Pp. 13-23.

McCall, John P. "The Squire in Wonderland." Chaucer Review, 1 (1966-7): 103-9.

McMillan, Ann. "Introduction" to tr. of The Legend of Good Women. Houston: Rice University Press, 1987. Pp. 1-55. 
Meditationes vitae Christi. In Sancti Bonaventurae Opera Omnia, Vol. XII. Ed. A.C. Peltier. Paris, 1868.

Meditations on the Life of Christ. Ed. and tr. Isa Ragusa and Rosalie B. Green. Princeton: Princeton University Press, 1961.

Mehl, Dieter. "The Story-Teller and His Audience: The Legend of Good Women." In Chaucer's Frame Tales: The Physical and the Metaphysical. Ed. Joerg O. Fichte. Cambridge: D.S. Brewer, 1987. Pp. 129-54.

Meiss, Millard. Painting in Florence and Siena After the Black Death. 1951. Rpt. New York: Harper and Row, 1973.

Minnis, A.J. Medieval Theory of Authorship: Scholastic Literary Attitudes in the Later Middle Ages. London: Scolar Press, 1984.

Mirk, John. Mirk's Festial: A Collection of Homilies by Johannes Mirkus (John Mirk). Ed. Theodor Erbe. EETS e.s. 96. London, 1905.

Muscatine, Charles. Chaucer and the French Tradition. Berkeley: University of California Press, 1957.

Neuschäfer, Hans-Jörg. "Boccace et l'origine de la nouvelle: le problème de la codification d'un genre médiéval." In La nouvelle: formation. codification et rayonnement d'un genre médiéval. Ed. Michelangelo Picone, Giuseppe Di Stefano, and Pamela D. Stewart. Montreal: Plato Academic Press, 1983. Pp. 103-110.

Ouspensky, Leonid, and Vladimir Lossky. The Meaning of Icons. Bern, 1952.

Overbeck, Pat Trefzger. "Chaucer's Good Woman." Chaucer Review, 2 (1967-8): 75-94.

Patterson, Lee $W$. "Pagan and Christian in the Testament of Cresseid." PQ, 52 (1973): 696-714.

Paull, Michael R. "The Influence of the Saint's Legend Genre in the Man of Law's Tale." Chaucer Review, 5 (1970-71): 17994.

Payne, Robert O. The Key of Remembrance: A Study of Chaucer's Poetics. New Haven: Yale University Press, 1963. 
Peterson, Joyce E. "The Finished Fragment: A Reassessment of the Squire's Tale." Chaucer Review, 5 (1970-71): 62-74.

Petrus Alfonsi. Disciplina clericalis. Tr. and ed. Eberhard Hermes. English tr. by P.R. Quarrie. Berkeley: University of California Press, 1977.

Poliakov, Léon. The History of Anti-Semitism, Volume One: From the Time of Christ to the Court Jews. Tr. Richard Howard. New York: The Vanguard Press, 1965.

Powell, Marianne. Fabula Docet: Studies in the Background and Interpretation of Henryson's Morall Fabillis. Odense University Press, 1983.

Price, Jocelyn G. "The Liflade of Seinte Iuliene and Hagiographic Convention." M\&H, n.s. 14 (1986): 37-58.

Reames, Sherry L. "The Cecilia Legend as Chaucer Inherited It and Retold It: The Disappearance of an Augustinian Ideal." Speculum, 55 (1980): 38-57.

---. The Legenda Aurea: A Reexamination of its Paradoxical History. Madison: University of Wisconsin Press, 1985.

-.-. "The Sources of Chaucer's 'Second Nun's Tale."' MP, 76 (1978-9): 111-35.

Reiss, Edmund. "A Critical Approach to the Middle English Lyric." College English, 27 (1966): 373- 79. Excerpt rpt. in Middle English Lyrics. Ed. Maxwell S. Luria and Richard L. Hoffman. New York: W.W. Norton, 1974. Pp. 317-21.

Rex, Richard. "Chaucer and the Jews." MLQ, 45 (1984): 107-22.

-.-. "Pastiche as Irony in the Prioress's Prologue and Tale." Studies in Short Fiction, 23 (1986): 1-8.

---. "Wild Horses, Justice, and Charity in the Prioress's Tale." Papers on Language and Literature, 22 (1986): 339-51.

Rowe, Donald $w$. Through Nature to Eternity: Chaucer's Legend of Good Women. Lincoln: University of Nebraska Press, 1988.

Russell, Jeffrey Burton. Satan: The Early Christian Tradition. Ithaca: Cornell University Press, 1981. 
Scarry, Elaine. The Body in Pain: The Making and Unmaking of the World. Oxford: Oxford University Press, 1985.

Schapiro, Meyer. "Muscipula Diaboli: The Symbolism of the Mérode Altarpiece" (Art Bulletin, 27 [1945]: 182-7) and "A Note on the Mérode Altarpiece" (Art Bulletin, 41 [1959]: 3278). Rpt. in Late Antique, Early Christian and Medieval Art: Selected Papers. New York: Braziller, 1979. Pp. 1-11 and $12-19$.

Scheps, Walter. "Chaucer's Man of Law and the Tale of Constance." PMLA, 89 (1974): 285-95.

Schoeck, R.J. "Chaucer's Prioress: Mercy and Tender Heart." The Bridge, 2 (1956): 239-55. Rpt. in Chaucer Criticism. Volume I: The Canterbury Tales. Ed. Richard J. Schoeck and Jerome Taylor. Notre Dame, IN: University of Notre Dame Press. Pp. 245-58.

Sinanoglou, Leah. "The Christ Child As Sacrifice: A Medieval Tradition and the Corpus Christi Plays." Speculum, 48 (1973): 491-509.

Singleton, Charles. Journey to Beatrice. Baltimore: Johns Hopkins University Press, 1958.

Smalley, Beryl. The Study of the Bible in the Middle Ages. 1952. Rpt. Notre Dame, IN: University of Notre Dame Press, 1964.

Smith, Barbara Herrnstein. On the Margins of Discourse: The Relation of Literature to Language. Chicago: University of Chicago Press, 1978.

The South English Legendary. Ed. Charlotte D'Evelyn and Anna J. Mill. EETS o.s. 235, 236, and 244. London, 1956 and 1959.

Stillwell, Gardiner. "Chaucer in Tartary." RES, 34 (1948): 17788.

Strohm, Paul. "Passioun, Lyf. Miracle, Legende: Some Generic Terms in Middle English Hagiographic Narrative." Chaucer Review, 10 (1975-6): 62-75 and 154-71.

Suleiman, Susan Rubin. Authoritarian Fictions: The Ideological Novel as a Literary Genre. New York: Columbia University Press, 1983. 
Trachtenberg, Joshua. The Devil and the Jews: The Medieval Conception of the Jew and Its Relation to Modern Antisemi-tism. New Haven: Yale University Press, 1943.

The Très Riches Heures of Jean. Duke of Berry. Facsimile with commentary by Jean Longnon, Raymond Cazelles, and Millard Meiss. New York: George Braziller, 1969.

Trivet, Nicholas. Les chroniques ecrites pour Marie d'Angleterre, fille d'Edward_I. Ed. Margaret Schlauch. In Sources and Analogues of Chaucer's Canterbury Tales. Ed.W.F. Bryan and Germaine Dempster. Chicago: University of Chicago Press, 1941. Pp. 165-80.

Tubach, Frederic C. "Exampla in the Decline." Traditio, 18 (1962): 407-17.

Vauchez, André. La sainteté en occident aux derniers siècles du Moyen Age, d'après les procès de canonisation et les documents hagiographiques. Rome: École Française de Rome. 1981.

Vickers, Brian. "On the Practicalities of Renaissance Rhetoric." In Rhetoric Revalued. Ed. Brian Vickers. Binghamton: Center for Medieval and Early Renaissance Studies, 1982. Pp. --.

Ward, Benedicta. Miracles and the Medieval Mind. Philadelphia: University of Pennsylvania Press, 1982.

Wee, David L. "The Temptation of Christ and the Motif of Divine Duplicity in the Corpus Christi Cycle Drama." MP, 72 (19745): $1-16$.

Weinstein, Donald, and Rudolph M. Bell. Saints and Society: The Two Worlds of Western Christendom, 1000-1700. Chicago: University of Chicago Press, 1982.

Weissman, Hope Phyllis. "Chaucer's Bad Tales." Dissertation, Columbia University. New York, 1973.

--. "Late Gothic Pathos in the Man of Law's Tale." Journal of Medieval and Renaissance Studies. 9 (1979): 133-53.

Wenzel, Siegfried. "Poets, Preachers, and the Plight of the Literary Critic." Speculum. 60 (1985): 343-63. 
--- Preachers, Poets, and the Early English Lyric. Princeton: Princeton University Press, 1986.

--- Verses in Sermons: Fasciculus morum and Its Middle English Poems. Cambridge: The Medieval Academy, 1978.

White, Helen C. Tudor Books of Saints and Martyrs. Madison: University of Wisconsin Press, 1963.

Witte, Stephen P. "Muscipula Diaboli and Chaucer's Portrait of the Prioress." Papers on Language and Literature. 13 (1977): 227-37.

Wood, Chauncey. "Chaucer's Man of Law as Interpreter." Traditio, 23 (1967): 149-90.

Woolf, Rosemary. The English Religious Lyric in the Middle Ages. London: Oxford University Press, 1968.

Wurtele, Douglas. "Prejudice and Chaucer's Prioress." Revue de l'Université d'Ottawa, 55 (1985): 33-43.

Yunck, John A. "Religious Elements in Chaucer's Man of Law's Tale." ELH, 27 (1960): 249-61.

Zumthor, Paul. "La brièveté comme forme." In La nouvelle: formation, codification et rayonnement d'un genre médiéval. Ed. Michelangelo Picone, Giuseppe DiStefano, and Pamela D. Stewart. Montreal: Plato Academic Pr., 1983. Pp. 3-8. 